\title{
WestVirginiaUniversity
}

THE RESEARCH REPOSITORY @ WVU

Graduate Theses, Dissertations, and Problem Reports

2015

\section{Collecting SubjectsObjects: The Museum and Victorian Literature 1830-1914}

Kayla Kreuger McKinney

Follow this and additional works at: https://researchrepository.wvu.edu/etd

\section{Recommended Citation}

Kreuger McKinney, Kayla, "Collecting SubjectsObjects: The Museum and Victorian Literature 1830-1914" (2015). Graduate Theses, Dissertations, and Problem Reports. 7103.

https://researchrepository.wvu.edu/etd/7103

This Dissertation is protected by copyright and/or related rights. It has been brought to you by the The Research Repository @ WVU with permission from the rights-holder(s). You are free to use this Dissertation in any way that is permitted by the copyright and related rights legislation that applies to your use. For other uses you must obtain permission from the rights-holder(s) directly, unless additional rights are indicated by a Creative Commons license in the record and/ or on the work itself. This Dissertation has been accepted for inclusion in WVU Graduate Theses, Dissertations, and Problem Reports collection by an authorized administrator of The Research Repository @ WVU.

For more information, please contact researchrepository@mail.wvu.edu. 
Collecting Subjects/Objects: The Museum and Victorian Literature 1830-1914

\author{
Kayla Kreuger McKinney \\ Dissertation submitted \\ to the Eberly College of Arts and Science \\ at West Virginia University \\ in partial fulfillment of the requirements for the degree of \\ Doctor of Philosophy in \\ English \\ John Lamb, Ph.D., Chair \\ Dennis Allen, Ph.D. \\ Marilyn Francus, Ph.D. \\ Ryan Claycomb, Ph.D \\ Donald Hall, Ph.D. \\ Department of English \\ Morgantown, West Virginia \\ 2015
}

Keywords: museum, natural history, Charles Dickens, Wilkie Collins, Henry Mayhew

Copyright 2015 Kayla Kreuger McKinney 


\begin{abstract}
Collecting Subjects/Objects: The Museum and Victorian Literature 1830-1914

Kayla Kreuger McKinney
\end{abstract}

This study argues that the museum wielded enough cultural capital to shape not only the content of literature (which picked up themes like collection, hoarding, display, and organization) but also the formal arrangement of such literature into catalogues, taxonomies, and the dense material-based descriptions for which the Victorian novel is often criticized. The museum, it is shown, is far more central to Victorian thought than has been recognized, and its presence in literature has been misread or overlooked in contemporary criticism. This study also provides a narrative of the Victorian preoccupation with the museual, especially as regards the natural history movement and the natural history museum. ${ }^{1}$ While there have been studies of the nineteenth-century museum and its appearance in literary texts, there has until now been no sustained account of the reach of its influence, nor has there been an attempt to represent Victorian views on the museual and its reach into everyday life. This study draws on the criticism of museum scholars such as Sharon Macdonald and Tony Bennett to examine the influence of the museum on key works of Victorian literature such as Charles Dickens's The Old Curiosity Shop and Our Mutual Friend, Henry Mayhew's 1851 and London Labour and the London Poor, and Wilkie Collins's The Woman in White.

\footnotetext{
${ }^{1}$ The museual, in my reading, encompasses the institutions that surround and share methods with the museum (fairs, human zoos, menageries, etc.) as well as aspects of the museum that travel into other cultural arenas.
}

[Type text] 


\section{Contents}

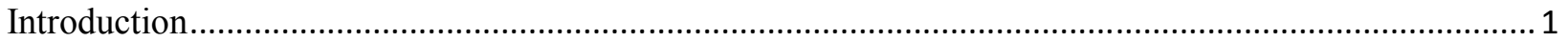

Chapter One: The Instructive Wax Girl and the Grotesque Imp: The Foundations of the Victorian Natural

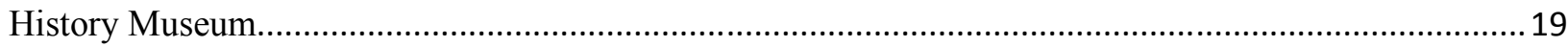

Chapter Two: Crystal Fragments: Museum Methods at The Great Exhibition, in London Labour and the

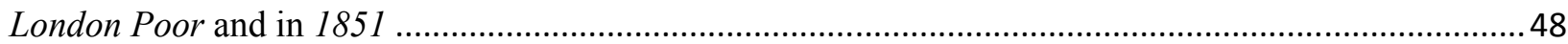

Chapter Three: "In that Bony Light”: The Museum Economy of Our Mutual Friend.............................. 79

Chapter Four: 'So Glad to Possess You:' Museual Echoes in Wilkie Collins's The Woman in White .... 106

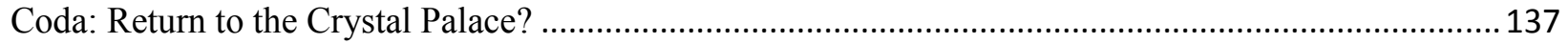

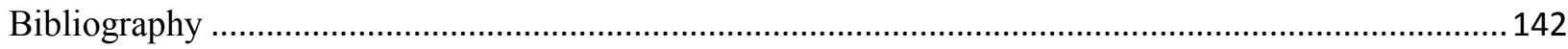




\section{Introduction}

In 1851, Punch looked ahead and reported that "We shall be disappointed if the next generation of London children are not brought up, like cucumbers, under glass" (63). In making such a prediction, Punch testified to the current influence of the Crystal Palace, itself a world enshrined beneath glittering panes of glass and predicted that this influence would be strong enough to shape Victorian building practices, aesthetic tastes, and even bodies. While it may not be immediately evident, Punch's predictions would prove sound throughout the nineteenth century as the cultural influence of the museum came to touch upon almost every aspect of Victorian life. In 1851 as a proto-museum, the Great Exhibition of the Works of Industry of All Nations, introduced Victorian visitors to the basic elements of museum culture and museum etiquette. The Exhibition and the cultural and material products associated with it (speeches, guidebooks, commemoratives, etc.) familiarized sight-seers with such museual tactics as display, spectacle, catalogue, evaluation, and taxonomy. Museum spaces also sought to discipline the bodies that entered them. What began with concerns about crowd control at the Exhibition developed into a philosophy in which the museum became a mechanism of social uplift and a place where the working classes could be instructed in middle class virtues and behavior.

This study examines the importance of the museum's influence on Victorian culture and traces the impact of that influence on and within literary works. It argues that the museum wielded enough cultural capital to shape not only the content of this literature (which picked up themes like collection, hoarding, display, and organization) but also the formal arrangement of such literature into catalogues, taxonomies, and the dense material-based descriptions for which the Victorian novel is often criticized. The museum, it is shown, is far more central to Victorian 
thought than has been recognized, and its presence in literature has been misread or overlooked in contemporary criticism.

This study does not offer a history of the museum's influence but, instead, provides a narrative of the Victorian preoccupation with the museual, especially as regards the natural history movement and the natural history museum. The museual, in my reading, encompasses the institutions that surround and share methods with the museum (fairs, human zoos, menageries, etc.) as well as aspects of the museum that travel into other cultural arenas. My argument is built on a study of Victorian engagement with the museum and its related institutions and practices, its connection to broader ethical, institutional, and national questions, and the ways in which these questions are reflected or explored in the literature of this period. One of the concerns of this study is how the Victorians moved from museum-making to cultural valuation, or the ways in which the methods of the museum migrated into the larger culture. One of the primary modes of this migration is in the pages of Victorian literature, especially the novels of Charles Dickens. Both within and outside of fictional worlds, the museum gave support to social Darwinism and the production of social taxonomies (as discussed in chapter two). The museum also taught Victorian viewers to extract lessons from objects and to read hierarchies of gender and of race (as discussed in chapter four). Finally, the museum's methods were promoted by a host of peripheral institutions from the Great Exhibition of 1851 to the freak shows and human zoos of the fin de siècle. While there have been previous studies of the nineteenth-century museum and its appearance in literary texts, there has until now been no sustained account of the reach of its influence, nor has there been an attempt to represent Victorian views on the museual and its impact on everyday life. 
Before discussing the critical framework of this study, it is important to note that there is no direct intersection of museum studies and the rise of the novel or literary culture. In attempting to address this lack, this study draws on a large body of recent criticism to discuss the museum as a cultural phenomenon that inflected and shaped Victorian literature and culture. The primary figures who underwrite and inform this project are Michel Foucault, Tony Bennett, and Barbara J. Black.

Although the work of philosopher Michel Foucault is varied and defies easy categorization, it has had wide influence on museum studies for thirty years. Foucault's ideas about disciplinary power, panopticism, and governmentality have also been applied to the development of the public museum in the nineteenth century. Victorian museums can be seen as Foucaultian spaces aimed at both improving the populace as a whole and instructing citizens in methods of self-regulation and self-policing. As disciplinary venues, nineteenth-century museums participated in the exercise of power by collecting, classifying, and ordering the world in the hopes of making it universally intelligible. The controlled use of knowledge and power through collection and display may be seen as a function of capitalism and imperialism. Further, Foucault marks museums as heterotopias, spaces in which culture is "at the same time represented, contested, and reversed, sorts of places that are outside all places, although they are actually localizable" (“Of Other Spaces” 178). Victorian museums functioned as heterotopias because they enclosed objects from multiple time periods and spaces but also because they became a space in which boundaries of class, race, and gender could be negotiated both in and outside exhibits. 
The scholarship of Tony Bennett builds on that of Foucault. Bennett's study, The Birth of the Museum: History, Theory, Politics, applies a Foucaultian lens to the museum in order to demonstrate that the museum not only instructed visitors in various disciplines, but regulated visitor behavior. ${ }^{2}$ Bennett also sees the heterotopic space of the museum in contrast to Foucault's other heterotopias such as fairgrounds and festivals. These heterotopias embody the irrational and chaotic elements that nineteenth-century museums sought to displace through order and organization. Despite its attempt to separate itself from these institutions, the museum, Bennett argues, shares with them "a concern to devise ways of regulating the conduct of their visitors ... ideally in ways that are both unobtrusive and self-perpetuating" (6). The methods of regulation used by these spaces and by the museum are Foucaultian in that visitors are taught to selfregulate their behavior, visitors believe that they are ever under surveillance, and visitors become the object made visible by the museum's different fields of knowledge while also functioning as "the subject that knows: enslaved sovereign, observed spectator" (7). Whereas Foucault defines "institutions of confinement" such as the prison, Bennett focuses on "institutions of exhibition," in which Foucault's surveillance (represented by the prison and the panopticon) and spectacle (public floggings and executions) exist simultaneously (59). In the institutions that belong to Bennett's "exhibitionary complex," self-disciplining is engendered by surveillance and reinforced through the spectacle of exhibition. Thus, in nineteenth-century museum spaces like the Crystal Palace, not only can everyone see all of the world (becoming subjects of knowledge and power) everyone can also be seen and know that they are seen (becoming the objects of knowledge and power).

\footnotetext{
${ }^{2}$ The central role of the visual in the museum is explored in this chapter through the work of Jonathan Crary and Lynn Merrill and complements Bennett's observations that the museum sought to create a single mode of viewing any given exhibit or object so that the viewer came to the intended conclusion.
} 
While Barbara J. Black acknowledges the work of Bennett and Foucault, her work, On Exhibit: Victorians and Their Museums, is situated in cultural studies and aims at "historical retrieval" and "literary interpretation" (6). Concentrating on Victorian London and its museums, Black argues that the nineteenth century gave birth to the modern museum. The rise of museum culture, she argues, is underpinned by imperialism, exploration, tourism, advances in science, the commitment to "improved public taste through mass education," "the growing hegemony of the middle class," the rise of fetishism and commodity culture, and the industrial revolution (9). Finding in the museum "a force to be reckoned with, understood, revised, discarded, [or ] embraced" Black examines the intersections between museums and literature by looking at literary objects as museum pieces, examining Victorian writings that take place within the museum, and by reading the museum and collection as an influence on Victorian poetry and imperialist boy fiction (17-18). Black shows that the museum's influence was not limited to public spaces (as Bennett argues), but that house museums and museum-themed literature could also replicate the disciplinary functions of the museum space. Both Black's understanding of the age of museum culture and her decision to read Victorian texts through a museual lens inspired this study. In noting Black's choice of texts, I was led to consider those that had been left out and to look at them with the museum in mind. Finally, while Foucault, Bennett, and Black form the critical foundation of this work, I also draw on the work of Thomas Richards, Anne McClintock, Sally Ledger, Roger Luckhurst, John Plotz, Stephen T. Asma, and Elaine Freedgood.

The narrative that I construct with the help of this critical foundation is two-fold. First, I trace the museum's historical development from its foundations in the pedagogical and the grotesque to its position as an institution with national influence. Secondly, I mark the museum's imprint on texts thematically and structurally and elaborate the museual mission to order and 
discipline bodies, whether these are bodies of texts, bodies that have been rendered into specimens, or human bodies that, through their gender, race, or class, threaten an established order. In explicating these views I focus on the writings of Charles Dickens, Wilkie Collins, and Henry Mayhew.

The novels discussed in this study have a place in the larger history of the museum. While Charles Dickens's The Old Curiosity Shop predates the Crystal Palace, it was published during the peak of a growing culture of natural history (Barber 9). The works of Henry Mayhew examined here, 1851 and London Labour and the London Poor, coincided with the opening of the Crystal Palace Exhibition and the moment when the Victorian world began to resemble the Victorian museum. Wilkie Collins's The Woman in White was published in 1859, the same year that the seminal natural history text Origin of Species was published. Charles Darwin, its author, would be among those who would petition to have the London Natural History Museum separated from the British Museum in order for the zoological and scientific specimens to more properly cared for, displayed, and appreciated (Browne 98). In 1864, when Charles Dickens's Our Mutual Friend was published, a competition was held to design the building that would hold the London Natural History Museum once it was moved out of the British Museum proper (Sheppard). ${ }^{3}$ The works of these authors may be more fully understood if they are examined through the lens of the museum. The narratives they construct reveal an engagement with museual concerns while the literal arrangement of their works reflects museual methods seen in museum publications and museum exhibits. Although my primary focus is on the reading of these texts, this study also emphasizes the pervasiveness of the museum's influence on everyday life and regular activity. The museum did not merely strike the fancy of a handful of prominent

\footnotetext{
${ }^{3}$ The Natural History Museum has been marked as one of the "museums of influence" that functioned during the reign of Queen Victoria (Hudson 10).
} 
writers. Rather, literature produced in this period demonstrates the importance of the museum in the wider culture.

As a background to my investigation of the museum, a brief history of the institution is necessary. While some scholars point to the Greek and Roman foundations of the museum, the origins of the public museum are usually traced to either the founding of the Ashmolean in 1683 or the opening of the Louvre to the public in 1793 (Abt 117). Prior to the opening of these displays to the public, collecting was usually the province of the wealthy, who could amass hunting trophies or purchase valuable works of art, or of the dedicated individual, often a naturalist, who displayed finds and creations alike inside of a personal curiosity cabinet. The first natural history museum was established in Paris in 1635 (Vincent H. Resh, Ring T. Cardé, Encyclopedia of Insects (2003), p. 771.). The development of the natural history museum occurred alongside the development of a greater museum culture. That the nineteenth century may be seen as "the age of the museum" is attested to by the fact that the handful of museums in the British Isles at the beginning of the century expanded to over 400 institutions by 1914, the year chosen for the end of this study (Bazin qtd. in Siegel vii). This museum age transpires concurrently with what Lynn L. Merrill and Lynn Barber have identified as the age of natural history, a period lasting roughly from 1820-1870. Like Britain's other museums, the natural history museum grew out of a handful of private collections (often in the form of curiosity cabinets) and house museums (Siegel 7). While the Ashmolean was the first public British museum to feature zoological specimens, the London museum may be seen as the first and most important of England's natural history museums (MacGregor 18). It is “to [Sir Hans] Sloane more than to any other man [that] the British Museum owes its existence," and the same can be said of London's Natural History Museum, as Sloane's collection makes up the foundation of 
both (Brooks 9). Sloane's zoological specimens underwent the transformation from a disorganized assemblage (parts of it lost, sold, or destroyed by various curators) in 1856 when Richard Owen became superintendent of the British Museum's natural history departments (Edwards 576, Eminent Persons 295). Under Owen, the collections were reimagined as part of a people's museum and plans to move the natural history collection were put in motion. These plans were realized in 1881 when the British Museum (Natural History) opened in South Kensington. Not until 1963 would the museum lose its designation of "British Museum" and emerge as an independent museum. While it rarely enters official accounts, part of the history of the natural history museum is a history of control. Beyond introducing its visitors to a field of study, the nineteenth-century museum sought to "educate it into a grouping of responsible and productive political subjects free from the dangerous passions of the mob" (Siegel 4). Achieved through surveillance and object lessons embedded in the exhibits, this attempt at control and at the dissemination of middle class values is as much a part of the Victorian natural history museum as its collections of fossils, specimens, and mounted beasts.

The development and growing popularity of natural history is tied to the development of the museum. Touted at various times throughout the nineteenth century as rational, godly, healthy, and educational, the observation, collection, or reproduction of natural objects became a Victorian fascination. Minor demonstrations or exhibitions introduced crowds to the microscope, and industrialization made it possible for the middle and working classes to acquire implements needed to unearth fossils, to collect and nurture various species of fern, and to bottle sea creatures deposited in tide pools by the retreating waves. This everyday collecting went on alongside the establishment of natural history museums, drew on the museum's resources, and was sometimes donated to the museum and featured in its halls. 
Embraced by the middle class as an institution that taught them how to spend their leisure time, the museum was also welcomed because it was seen as a mechanism through which the social uplift of the working and lower classes could be achieved. In the Victorian era, museums began to solidify their associations with class and learning, and tensions arose between the museum enterprise and other entertainments that sought to present themselves as sister forms of rational recreation. In 1851, the Great Exhibition made the museum a point of national pride, and the popularity of the display indoctrinated six million visitors in the museual methods of display, authentification, and taxonomy. Exhibitions would ripple out across the world, gathering large crowds for another eighty years - an indication of the popularity of the museum and the museual impulses of the viewing public. By the end of the nineteenth century, imperial displays and human zoos grew up alongside the museum, making it profitable and normative to display the human body alongside that of other beasts.

In my discussion of the museum, I argue that the popularity of natural history is an indication that museual processes and methods entered the public domain and exerted influence on the way that Victorians interacted with their world. While I agree with Black and Bennett that museums sought to discipline bodies and provide moral uplift, I expand upon their argument to show that the museum also exerted this influence through various types of literature and even influenced this literature's shape. Transmitted through public exhibitions, guidebooks, natural history texts and a proliferation of materials used for collection and display, museum culture became part of the fabric of Victorian life and was reflected in Victorian writing.

The first chapter of this study, "The Instructive Wax Girl and the Grotesque Imp: The Foundations of the Victorian Natural History Museum," argues that the vision of the museum as a pedagogic space - clean, organized, and intellectual - actually acts as a shield or an alibi for 
the museum's grounding in the grotesque. The museum, especially the natural history museum, is a space where education is often based in the unpleasant, the uncanny, or the revolting. In order to function as specimens, bodies must be cleaned of flesh and sinew, drained of blood and mucus, and repositioned in lifelike poses. In order to discuss the public and private spaces of the museum, this chapter enters the museual space of Charles Dickens's The Old Curiosity Shop. In my reading of the novel, I link Nell Trent to the museum's educating, regulating mission and show that the novel's characters interact with Nell as they would interact with a nineteenthcentury exhibit. Since the museum has been studied alongside the fair and international exhibitions (spaces that I mark as museual), I also examine the tension between rational recreation and entertainment in the text.

Realms of popular entertainment are represented in The Old Curiosity Shop in the character of Daniel Quilp, a character set in direct opposition to Little Nell. ${ }^{4}$ Together these two characters embody the traits that formed the foundation of the Victorian museum and, though they appear to be in conflict, these traits actually rely on and build upon one another. The entertaining aspects of the museum represented by Quilp were often necessary to draw audiences inside the museum so that it could deliver its educational message and discipline those audiences in proper middle class modes of behavior. ${ }^{5}$

Dickens's novel lends itself to a museual reading because its narrative world is one that is obsessed with sight and vision. The Old Curiosity Shop's quickly discarded narrator, for example, is engaged in flánaerie when the novel begins. Due to this preoccupation with sight and

\footnotetext{
${ }^{4}$ To expand on and to provide a historical overview of the popular entertainments Bennett discusses, I draw on the work of Richard D. Altick.

${ }^{5}$ Barbara J. Black's scholarship demonstrates the Victorian affinity for exhibits that relied upon contrast to teach their audiences. For example, a museum might display "an athlete's arm [beside that of] a sedentary person," or contrast "the stomach of a healthy person with that of a drunkard" in order to teach a lesson (34). In the same way, Dickens contrasts Nell and Quilp.
} 
observation, this chapter relies heavily on the theoretical work of Jonathan Crary. In his investigations of nineteenth-century visual culture, Crary argues that changing visual modes privileged sight as never before. This change led to increased visual learning and a preoccupation with a pedagogy rooted in vision and forwarded through the museum, visual exhibitions, and the microscope. In Dickens' novel, Nell Trent and Daniel Quilp are put on display as museum exhibits, cleverly constructed props meant to supply the reader with a lesson. When read with the museum in mind, the two can be seen as the institution's two halves, with Nell representing the instructive and Quilp representing the grotesque. Although Curiosity Shop does not take place within the walls of the museum, the novel is composed of a series of exhibitionary spaces that ultimately point toward Nell's final exhibition in death. These include: the shop itself, Mrs. Jarley's Waxworks, and the church. In these spaces, Nell functions as an example of innocence and goodness meant to instruct the reader. As a "tour guide" for the Waxworks, Nell even enters the museual space as an instructor.

Though Nell is often made into an exhibit, the dwarfish Quilp puts himself on display. As a contrast to Nell, Quilp stands for everything that the museum seeks to hide away: destruction of bodies, imperialism, and its association with popular museual spaces like the freak show. Quilp also embodies a warped version of the museum's obsession with sight as the character most often engaged in spying. Even without his fantastical antics, Quilp's sheer physical appearance would qualify him for inclusion in a freak show, and he enjoys frightening and tormenting the other characters with his looks. By representing the freakish and the grotesque, Quilp also acts as something against which the legitimate educational messages of the museum might be defined; he is that which the museum is not. In the end, the pedagogic must rely on the grotesque, as Nell's final lesson is taught in the form of her dead body. Only in death can objects 
be stilled and studied, and it is in death that Nell's value becomes the most clear. Everything about her can be put on display and admired. Without the destruction of blood and bone and fur and feathers the natural history museum could not create instructional narratives. Without the threat of Quilp and the specter of death, Nell could not serve her educational mission.

While the natural history museum did much to educate those who crossed its threshold, the high watermark of the Victorian museum's influence can be found in the Great Exhibition, which introduced thousands of visitors to museual methods such as catalogue and taxonomy. In the second chapter, "Crystal Fragments: Museum Methods at The Great Exhibition, in London Labour and the London Poor and 1851," I chart the expansion of the museum's methods into the realm of literature and examine the Crystal Palace as an example of Michel Foucault's heteroclite, a site of "disorder in which fragments of a large number of possible orders glitter separately in the dimension, without law" (The Order of Things xvii).Guidebooks and museum catalogues were used to discipline this site, ameliorate visitor anxiety, and codify and contain the wonders of the Crystal Palace. These attempts at containment also appear in Henry Mayhew's London Labour and the London Poor, where the journalist attempts to discipline and order the world of the poor in the same way that audiences used catalogue and taxonomy to discipline and order the world of the Crystal Palace. Finally, this chapter examines Mayhew's little read 1851, where the museum world created by the Great Exhibition is exaggerated and mocked and where the museum begins to discipline individuals far more than museum visitors can discipline the contents of the museum. The transfer of museual methods of discipline to the social sphere in London Labour and to the world of the novel in 1851 and highlights the reach of the museum's influence in the nineteenth century. 
Mayhew's work supports a museual reading because of his turn toward strategies of taxonomy, evaluation, and catalogue. In London Labour such methods become the manner in which "the misery, the vice, the ignorance, and the want" of the Victorian poor becomes organized and understood (447). Mayhew's mission, like that espoused by the nineteenth-century museum, is one of social uplift. In presenting his catalogue of the poor, he hopes to change attitudes about them and to "induce" his readers "to apply [themselves] steadfastly to the removal or alleviation of those social evils that appear to create so large a proportion of ... vice and crime" (447). Reading Mayhew's work, upper and middle class Victorians became skilled students of taxonomy, capable of distinguishing individuals on the street down to the hyperspecific "species" or "subspecies" level. The streets of London became a museual space where the average person could practice the museum's methods as they assess and categorize their fellow citizens. Taxonomic work becomes the work of the middle class rather than the work of an individual scientist.

In 1851, Mayhew shifts from the use of museual tactics to imagining the world as a museum. In the first pages of the novel, the reader is indoctrinated into the world of the catalogue, the most popular museual method used by journalists and guidebook writers. The text then moves from narrative to catalogue, echoing both form and content of the museum guides that became so popular with the opening of the Great exhibition. The novel also provides a detailed taxonomy of London thieves and suggests that the city might not be just a showcase for items and goods, but a living, moving museum space full of unsavory specimens. At the same time that the text is being transformed into a string of lists, the world of 1851 is being made into a museum, rife with all of the problems that plagued visitors of the Crystal Palace. The solution to all of the problems in the novel is ever present, shimmering the distance. Not only does the 
Crystal Palace offer entertainment and fun, but it should cure the rustic Sandboys clan of their backwardness, their ignorance concerning London's inhabitants, and their lack of fashion sense. This is a nearly perfect echo of the promise that the Crystal Palace held out to members of the Victorian working class and Mayhew's comic novel demonstrates its limitations.

The third chapter, “'In that Bony Light:” The Museum Economy of Our Mutual Friend," shifts the focus from the creation of consumers to the ways in which the body might be consumed. Expanding upon the natural history museum's foundations in the grotesque (as discussed in chapter one), this chapter illuminates the vampiric economy at the museum's heart. This economy relies upon the destruction of animal (and sometimes human) bodies in order to create valuable specimens to display. In Our Mutual Friend, Charles Dickens borrows this economy as the basis of his plot and as a device that shapes the relationship between John Harmon and Bella Wilfer. Both become valuable through death, with Harmon even concealing his identity in order to remain dead to further evaluate his prospective bride, and Bella rising to prominence because Harmon is presumed dead.

While the museum's economy this is the primary link between the text and the natural history museum, the novel is ripe with other museual themes. The tensions inherent in collecting are illuminated through the character of Mr. Venus who represents both the ameliorative powers of a museum-based life and the threatening power of the museum through his ability to turn dead bodies into specimens. Mr. and Mrs. Boffin display and authenticate Bella Wilfer, while Harmon must accept or reject his identity as a collector/connoisseur. By placing a museum economy at the heart of the novel, Dickens illustrates some of the ways that the museum directed discourse, dominated scientific understanding, and influenced the economic ideology of the mid-nineteenth century. 
The opening section of the chapter illuminates the influence of the museum on Our Mutual Friend and argues that a museual reading helps to recover characters that have not been thoroughly studied. In this section, I examine Gaffer Hexam, Silas Wegg, the Boffins, Bella, Eugene Wrayburn, Mr. Riah, and Jenny Wren, characters who are shown to be collectors, fláneurs, and exhibitions. These minor characters help to anchor the novel in a world shaped by the museum and attest to Dickens's interest in museual culture. I also investigate Mr. Boffin's counterfeit identity as a collector and miser and John Harmon's decision to reject his identity through death rather than collect Bella Wilfer as an inheritance.

In the second part of the chapter, I turn to the vampiric economy at the heart of the museum. This economy destroys the living body in order to create a specimen. This specimen is then valued for its usefulness as an educational object. Mr. Venus introduces the reader to this economy when he discusses his work in taxidermy. While the text's primary characters do not engage in the work of mounting animal bodies and selling them, Dickens uses the museual concept of value-through-death in connection with the Hexam family, who draw bodies from the river and collect rewards for their recovery, the Boffins, who acquire their social position through death, and John Harmon, who pretends to be dead in order to evaluate Bella. Death and value intersect over and over in the text as they do inside of the museum.

The chapter also examines an alternative to the darker aspects of the museum discussed above. Through the character of Mr. Venus, Dickens reveals that he does not see the museum in an entirely negative light. Through his museual occupation, Venus creates a narrative for his life, makes a name for himself, improves his knowledge, and gains in wealth through his shop. His shop also dispenses narratives, wholes made from parts that echo the narratives created by the museum. The chapter concludes with an examination of John Harmon and his determination to 
reject a particular museual narrative (that of the connoisseur) and traces the connections between the domestic space and the space of the museum. Domestic collecting and house-museums were an integral part of the museum culture that flourished at mid-century, and Dickens does not hesitate to invite the museum home.

The museum reaffirms these domestic ties in the final chapter, "'So Glad to Possess You:' Museual Echoes in Wilkie Collins's The Woman in White." Therein, the museum's influence appears in the perceptions of individuals as objects, and in the museum-related rituals of collection and possession, all undertaken in estates rather than in the museum proper. Objects and subjects become so enmeshed that the Victorian anxiety of the two becoming interchangeable is realized. Walter Hartright, the protagonist, begins the novel as a possession, a drawing master under the employ of collector and master of Limmeridge House, Frederick Fairlie. As the story progresses, he will journey from this feminized position to that of a cultured, cosmopolitan, and enlightened male - the very figure targeted by the nineteenth-century museum (Duncan 127). In order for this transformation to take place, Hartright must become a connoisseur, in possession of beautiful objects.

The novel opens with Walter Hartright engaged by Frederick Fairlie as a drawing tutor for his nieces. Hartright's work at Limmeridge House (a museum space in which the characters dwell) may be linked to the popularization of natural history, as he instructs the young women in painting from nature. As an instructor, Hartright also joins the cast of Victorian characters listed above in the act of viewing. In Hartright's case, his viewing has often been connected to the male gaze. This study seeks to expand and complicate this reading by arguing that scopophilic moments may also be museual ones. In the museum, vision is used not only to express desire, but to assess, authenticate, and to assign value to the female bodies it encounters. Hartright's 
assessing gaze both implicates the museum as a patriarchal institution and indicates that its reach was broad enough to influence the content of the sensational novel.

The museum also evaluates and arranges bodies in taxonomies and hierarchies. In the nineteenth century, these arrangements included the accepted truth that the female body was weaker than the male. The female intellect was also held to be less, and the female form ultimately occupied a lower place (and possessed lower worth as a result). This study argues that The Woman in White can only function as a narrative if its readers accept Hartright's (and the museum's) view of female frailty, a frailty exhibited in each of the major female characters within the text. The echo of Anne in Laura's features suggests both that female bodies share essential natures and one may be read as a key to all (a practice embraced by the museum) and that their minds, too, may be alike. Their similarities then allow for one woman to stand in for the other - they become as interchangeable as specimens.

While Hartright is not evaluated quite as harshly as his pupils, the struggles he faces stem from the museum. The conflation of object and subject was not completely new to the Victorians (slavery having existed since ancient times) but the rise of museum culture brought concerns about the mutability of subjects into objects to the fore. At Limmeridge House, Hartright's subjectivity is threatened as Fairlie seeks to make him part of his collection. To escape this fate, Hartright will ultimately engage in the museual work of authentification by attempting to restore the lost wealth of Laura Fairlie (now Lady Glyde) who is presumed dead. As the restorer of Laura and the only one who could see her value when she was disguised, Hartright secures reputation and status and becomes the master of a space where he formerly feared being regarded as an object instead of as an artist. 
The wide array of topics discussed here - individuals made into objects, novels transformed into catalogues, the destruction of the body for educational purposes - suggests the wealth of critical avenues that may be explored when a museual lens is used. Though I have discussed only four authors in this study, a wealth of Victorian writings could be assessed using museum criticism, including works by George Eliot, Oscar Wilde, Dante Gabriel Rossetti, Michael Field, and Rudyard Kipling. Beyond the realm of novels and poetry, little-studied museual literature exists in the form of catalogues, nature writings, travelogues, taxidermy manuals, and advertisements. It is my hope that this study and others like it will increase the critical conversation surrounding the museum and expand the context in which Victorian literature is discussed, studied, and understood. 


\section{Chapter One: The Instructive Wax Girl and the Grotesque Imp: The Foundations of the}

\section{Victorian Natural History Museum}

The nineteenth century did not invent the museum. However, during the heyday of museum culture, middle class Victorians looked to this institution as a structure that could educate and reform its visitors, especially those of the working classes (Black 32). In order for the museum to fulfill its teaching mission, it simultaneously distanced itself from and relied upon peripheral institutions like fairs, freak shows, menageries, and scientific demonstrations. These mixtures of entertainment and education drew viewers in with displays of the uncanny, the unbelievable and the grotesque. Though rarely acknowledged, this grotesquerie could also be found in the natural history museum, an institution with foundations of blood, bone, and viscera. The museum, so often used to teach narratives of health, proper behavior, and order, did so by consuming and destroying animal and even human bodies in order to stage its elaborate teaching exhibits. Though never explicitly mentioned in Charles Dickens's The Old Curiosity Shop, the museum's foundations appear throughout the novel in the form of two of its principal characters: Nell Trent and Daniel Quilp.

Through these characters, the world of The Old Curiosity Shop creates a dichotomy of good and evil, of fairy princess and covetous troll, and of pastoral angel and urban trickster. This chapter seeks to add to this list the contrast between the legitimate museum enterprise and the entertainments that formed a periphery around the museum, such as the fair, the circus, the freak show, and the travelling menagerie. Museum scholar Tony Bennett defines these peripheral institutions as dark heterotopias, spaces that, as Foucault argued, privilege "time in the mode of the festival" and "teem... with stands, displays, heteroclite objects, wrestlers, snake-men, [and] 
fortune-tellers" (Bennett 1, Foucault The Order of Things 26). Emphasizing a scientific and educational mission, the Victorian museum "sought constantly to extract itself" from the popular entertainments which encroached on it (Bennett 3). The energetic efforts of curators to keep the marvelous, fantastic, and exotic at bay may have been because the disorganization, display of curiosities, and chaos of these types of entertainments mirrored the museum's past incarnations too closely. In The Old Curiosity Shop, the threat of these popular entertainments is embodied in Quilp, who threatens, pursues, and covets Little Nell, representative of the educational and moral principles of the Victorian museum.

Predating the museum, the freak show is one of the many institutions curators sought to label as anti-museual. Historian Richard D. Altick traces freakery in Britain to the sixteenth century where the "new affluence which marked the century" manifested itself in "the occasional copper or two, sometimes a shilling, to spend on amusement" (34). These amusements grew apace with popular demand until lions, tigers, elephants, and human curiosities could be found in almost every London street. By the nineteenth century, Britain had still not outgrown the desire to gaze and to gape at "human wonders, whether natural or contrived" (Altick 253). While these later performances did take place in the museual era when a "new zeal for popular education" and rational recreation was sweeping the country, such high-minded ideals did nothing to diminish the crowds at the traveling carnival or freak show, and these exhibitions "provided a welcome strand of continuity" in the history of the museum periphery (Altick 253).

Through his association with the freak show, which will be elaborated below, The Old Curiosity Shop's Daniel Quilp is marked out as a representative of the dark side of the museum, the peripheral and sometimes unsavory institutions that used its method of acquisition and display to draw in a paying audience. His antithesis, Nell, is associated with goodness and 
innocence, but also with the legitimacy of the museum proper. It is her very association with these things that causes her to be sacrificed to the vampiric economy of the museum, an economy that creates value through destruction. As the educational exhibit at the center of Curiosity Shop where she is displayed like a natural history specimen, Nell is allied with the scientific and the instructional. Quilp, with his stolen hoard, is linked to "ornamental value," "exotic qualities," and an attention to "the marvellous [sic] and fantastic" - all qualities of the museum's peripheral and illegitimate institutions (Bennett 3).

While the scientists and curators of the nineteenth century may have imagined that the world would have been a better place without these illegitimate side shows, such institutions allowed the museum to define itself. The museum requires all the grotesquerie of Quilp in order to create the educational exhibits represented by a character like Little Nell. Without the destruction of blood and bone and fur and feathers, the natural history museum could not create instructional narratives. Of course, the literal display of blood and bones remains undesirable. Ignoring its foundations in the grotesque, the museum points a disapproving finger at other venues which exploit and exhibit bodies living and dead. However, as this chapter will argue, Nell and the museum could not serve their functions without the threat of Quilp and all that he represents. Though often in apparent conflict, Nell and Quilp represent two joined museual concepts that make up the foundation of the natural history museum: the educational and the grotesque. Together, the concepts represented by these characters make up the public and private face of the Victorian museum.

Charles Dickens's The Old Curiosity Shop is best remembered for its female heroine and her overly sentimentalized death. Even in collections of Dickens scholarship like Contemporary Dickens the novel gets scant mention (a mere seven times) compared to other giants in the 
Dickens canon like David Copperfield (17 mentions), Bleak House (23) and Little Dorrit (19). In its own time, however, The Old Curiosity Shop enjoyed incredible popularity, and an entire discourse formed around Little Nell and whether or not she would survive (Gillooly and David 177). Ironically, Dickens' decision to kill the child may have done more to establish her immortality than any happy ending or clever narrative twist could ever have done. With constant foreshadowing and symbolism grounding Nell in heaven (and thereby, also, in death) Dickens creates a character that is more object than personality - an exhibit that may be put on display to aid in the instruction of readers. Little Nell is a literary museum piece.

Though criticism has not seen The Old Curiosity Shop as a museual text, scholars have correctly associated it with the visual culture so crucial to the museum. ${ }^{6}$ While acknowledging that the "attention accorded to speaking, hearing, and touching in contemporary museum practices" may usurp the "primacy of the visual," the visual was the nineteenth-century museum's primary mode of instruction (Bennett "Civic Seeing” 267, Merrill 111). Natural history museums emphasized "careful scrutiny," "meticulous observation," and the transparent visibility of nature and of science (Merrill 107). The importance of visual culture in the museum is highlighted by Jonathan Crary who notes that "the making, the consumption, and the effectiveness" of museum objects such as art "is dependent on the observer"; without a pair of eyes to look at them, museum objects can convey no message (23).

In The Old Curiosity Shop, no character is more watched than Little Nell. ${ }^{7}$ The intense voyeurism of the novel has been noted by Patricia McKee (110), James Kinkaid (37, 42, 43), and Mary Klages (139-140). "Liv[ing] in an Exhibition-room,” Nell is subjected to endless

\footnotetext{
${ }^{6}$ Visual culture was essential to nineteenth-century understanding, as discussed by Lynn L. Merrill (107-137) and Aileen Fyfe and Bernard Lightman (1-22).

${ }^{7}$ Kit gives up his sleep to watch "in the open street for fear any harm should come to [Nell]," while Quilp watches her with "an admiring leer" (Dickens 133, 125). Master Humphrey, Nell's grandfather, and her travelling companions make up other audiences for the girl-exhibit. For a consideration of Nell on exhibit, see Galletti 53-55.
} 
observation: she is contemplated by Master Humphrey, watched for by Kit, watched over by her grandfather, leered at by the voyeuristic Quilp, and even exhibited, in death, to the reader (Schlicke 99). With so many eyes (not least, the reader's) resting on her, Nell becomes a fitting object for the application of museum theory. By treating her as a museum exhibit, one can begin to see that her meaning is often dependent on the context in which she is displayed. ${ }^{8}$ The museum-like space of the curiosity shop highlights her innocence and vulnerability, the waxwork exhibits show her beauty and value, and the gothic space of the church remakes her into an angel. The Old Curiosity Shop is composed of a series of exhibitionary spaces that point toward Nell's final exhibition in death.

Long before her death, and even before Nell is displayed among all of the curiosities, the reader is alerted to the influence of the museum on the text. ${ }^{9}$ The Old Curiosity Shop begins with a narrator engaged in the practice of observation, a practice befitting the museum culture of the nineteenth century. This narrator is a flâneur, roaming the streets in order to see "a glimpse of passing faces caught by the light of a street light or shop window" (Dickens 43). ${ }^{10}$ The figure of the flâneur has often been seen as a part of the museum's visual culture, capable of creating a panorama (a museual device) of the cityscape (Brand 6). ${ }^{11}$ Under the eyes of the narrator/flâneur, Nell is first subjected to the viewing that will mark her character throughout the text. The

\footnotetext{
${ }^{8}$ Furthermore, such an analysis is supported by what Michael Hollington calls Dickens's tendency to "thoroughly and pervasively... confus[e] the category of persons and things" (2). Nell can easily be read as an object because even her creator fails to uphold strict boundaries between subjects and objects in his work.

${ }^{9}$ A further museum connection exists in the novel's preoccupation with time. The museum is an institution with an obvious investment in time and in history while Curiosity Shop "emphasizes the mortality of men and things... reminding the reader that he, too, is on his way to becoming a curiosity" (Rogers 127).

${ }^{10}$ For a discussion of the narrator's roaming, see Maglioni, Silvia. "The Old Curiosity Shop: Cartographies of Motion." Dickens: The Craft of Fiction and the Challenges of Reading, Proceedings of the Milan Symposium, Gargnano 1998. (2000): 225. Print.

${ }^{11}$ While this text examines American literature, it focuses on an English-language tradition of the flaneur and can be readily applied to Dickens.
} 
narrator's fascination with her helps to guide the eyes of the reader, making Nell the focus point. ${ }^{12}$

Escorted home by the narrator, Nell then makes a proper museual debut. Within the curiosity shop, she is displayed among "old and curious things": "suits of mail," "fantastic carvings," "rusty weapons," "distorted figures in china and wood and iron and ivory," as well as "tapestry" and "strange furniture that might have been designed in dreams" (Dickens 47). Interestingly, the narrator resists the idea of Nell as part of this strange exhibit and insists that the centerpiece, the thing that gives these objects meaning, is the girl's grandfather. He remarks, "There was nothing in the whole collection but was in keeping with himself; nothing that looked older or more worn than he" (Dickens 47). Despite this initial observation, it is not to thoughts of the grandfather that the narrator will continually return. Instead, upon leaving the curiosity shop, his mind makes its way back to the image/fantasy of Nell and he "picture[s] ... the child in her bed: alone, unwatched, uncared for (save by angels), yet sleeping peacefully" (Dickens 55). ${ }^{13}$ All of the miscellaneous items of the curiosity shop seemed to have been brought to rest around Nell, pulled in by a purposeful tide; they are part of her exhibit, objects that give her meaning through contrast.

At the most basic level, exhibits are objects or artifacts put on display in order to represent a concept or show an example. Today, as in the nineteenth century, exhibits often consist of more than one specimen, and the overall meaning of the display arises from the juxtaposition of these objects, the ways in which they illuminate one another. Many of these

\footnotetext{
${ }^{12}$ One of the ways the museum worked in the Victorian era was to provide a single viewpoint, "arrang[ing] and display[ing] natural and cultural artefacts" for "the increase of knowledge" (Bennett 24, Goode 3 qtd. in Bennett). Nell is used this way in Curiosity Shop. The reader is made to focus on and learn from her.

${ }^{13}$ Tony Giffone reads this return to Nell as "lust" wherein Nell is transformed into "a creature of [the narrator's] obsessions." The rest of the novel is then read as a dream, a fiction of "lost innocence" that the narrator builds up around Nell (105).
} 
objects provide an "extremely personal" "historical context" alongside their educational value; they may inspire nostalgia and "backward-looking ... bitter-sweet" feelings in their viewers (Pearce 20). Victorian museum-goers would have been particularly familiar with the depth of emotion stirred by personal exhibits. The nation was well-aware of Queen Victoria's personal museum making through the creation of the "Albert Room" in Windsor Castle, a space filled with mementoes commemorating her lost husband (Marsden 336). Both Victoria and Albert also sent personal items such as jewelry to be displayed at the Great Exhibition and other museual spaces (Marsden 343). ${ }^{14}$ Aware of the nostalgia and emotionality attributed to such objects, Dickens transfers them to the object he makes of Little Nell. Like the objects arranged inside of display cases in the museum, her meaning is emotionally shaded and shifts based on the environment in which she is placed or the objects that share space with her.

The contrast between Nell and the other objects that clutter her first display space are much in the mind of the narrator when thoughts of Nell in that "gloomy" and "uncongenial place" impress themselves upon him and keep him from his bed (Dickens 53, 55).Though he believes the collection a fitting exhibit for the grandfather, the narrator soon admits that "I am not sure I should have been so thoroughly possessed by this one subject" (Nell) had it not been "for the heaps of fantastic things I had seen huddled together in the curiosity-dealer's warehouse" (Dickens 56). The weapons and armor and figures and furniture surrounding Nell assist the narrator in making meaning. He comes very clear to expressing this directly when he notes that the items "gathering round her... brought her condition palpably before me" (Dickens 56). Despite his best efforts, he cannot imagine Nell into an ordinary chamber, surrounded by the ordinary markers of childhood (Dickens 56). The objects surrounding her become necessary to emphasize her as a representation of innocence. Her nature is highlighted and heightened

\footnotetext{
${ }^{14}$ For a spectacular visual tour of these treasures, see Marsden pp 335-346.
} 
because she is seen beside weaponry, she becomes more familiar and readable because she is surrounded by the foreign and the exotic, and she becomes timelier because she is shown in the midst of relics from the past. Just as Nell is made into a representative object, these objects are imprinted with subjectivity; for instance, the critic Maxwell sees in "the chaos of evocative things jumbled on all sides of the girl" a vision of the crowd that daily fills London's streets (53, 49). In the exhibitionary space of the curiosity shop, objects stand in for real world subjects and the girl at their center becomes an object of interest for Master Humphrey as well as for the reader. Nell is being built up into a teaching object, the primary role of exhibits in the Victorian museum. ${ }^{15}$ She is the ever-visible parts of the museum, the clean, the educational, and the socially valuable.

Subjected to such a reading, Nell is transformed from a young girl under the misguided care of her grandfather into a symbol of innocence. Museual objects also undergo this type of transformation. A human skeleton becomes a teaching tool when positioned next to the "Irish Giant" in London's Hunterian Museum, their contrast igniting a discussion about growth, bone structure, and hormone production (which could lead to gigantism). ${ }^{16}$ The ways in which the narrator interprets the objects sharing Nell's space is an example of a museual reading which relies on the context and placement of the objects in the exhibit in order to make meaning. Since

\footnotetext{
${ }^{15}$ Nell's swift transformation from a character into an object is only reinforced by the narrator's recourse to allegory. In allegory, characters are read as symbols. Likewise, in a museum exhibit, objects can be interpreted in the same way. The narrator's decision to read Nell as if she "exist[ed] in a kind of allegory" (a hint, presumably, to the reader) creates a connection between the novel and the museum (Dickens 56). The same type of reading goes on in both. The Old Curiosity Shop is often read as an allegory. John W. Gibson reads the novel as an allegory in which "character relationships personify the incessant warring of vice and virtue" (178). The Victorian museum often constructed exhibits that showed the effects of vice beside those of virtue, so such a reading need not be entirely dismissed here, even though Gibson does forward it largely to save Curiosity Shop from "apologetics" and "disrepute" (178). The idea of Nell as an object is also discussed by Cleere (58).

${ }^{16}$ The story of Hunter's acquisition of this skeleton may be found in Asma (60-62). Today, there is controversy over the museum's possession of it (Dalrymple).
} 
the arms and mail surrounding Nell are "rusty," they should be of no threat to the sleeping child. However, the narrator imagines them into life as "wild, grotesque companions" that only serve to illuminate her as a "pure, fresh, youthful object" (56, my emphasis). Likewise, the objects kept for sale around her become "everything... foreign to [her] nature, and furthest removed from the sympathies of her age and sex" (Dickens 56). Nell's presence acts as a foil to these mute things, investing them with the ability to threaten and highlighting the Victorian conflation between subjects and the objects they collected. ${ }^{17}$ The objects seem to come alive while Nell becomes more a symbol than a character, a representation of innocence on display for the reader.

Before turning to the other displays of Nell, it should be noted that display was not solely the province of the museum. The Punch and Judy Show, the fair, the freak show, public scientific demonstrations, the menagerie and late-century imperial exhibits all also relied upon displays and all attempted to emphasize their educational as well as entertainment value. Unfortunately the educational merit of "advanced principles of museum science" struggled and failed to "entirely displace the basic, visceral pleasure to be had in looking at freaks of nature" (Merrill 109). Yet these freakish displays, seen as illegitimate by the museum, are as much a part of its foundation as the clean, well-lit, educational exhibits arranged in order to reform the working classes through example. Victorian museums, especially natural history museums, created their exhibits using methods that were as likely to induce shivers and cries as any "monster" put on

\footnotetext{
${ }^{17}$ This may be clearly seen in the text's narration of the adventures of Nell's bird. Nell has little that Plotz would consider to be portable property; she takes almost nothing with her but a bit of clothing and a gold piece that she sews into her dress. The bird that she leaves behind, however, comes to represent her goodness and character even when she is removed from the scene. It does so strongly enough that Kit suffers a "swoln [sic] and bruised face" to prevent its death, and then "exhibit[s]" the bird to his siblings as "a great and precious rarity" $(161,162)$. The bird was a popular display choice in natural history museums and several prominent naturalists made their reputations from the artistic representation of them. In "The Tresses of the Day Star," Dickens marvels over just such specimens and the lifelike impression they make: "When we leave the building in which many hundreds of these exquisite things are grouped under glass-cases [sic], we will strive to forget that their beauty is not quite animate" (289). In chapter three, we will see Dickens return to such a specimen to attest to the artistry present in museum specimens.
} 
display in the back room of a public house or at a country fair. ${ }^{18}$ In order to prepare a specimen, a naturalist would first have to kill. Next, flesh might be boiled from bone or flesh-eating beetles employed to reduce a body to a pile of bones. In the case of The Old Curiosity Shop, the dark heart of the museum enterprise - the grotesque, uncanny, unnatural, disturbing and disgusting elements needed to support the museum's pedagogical mission - is exemplified by the nightmarish exhibit of Daniel Quilp. ${ }^{19}$

While Nell is often made into an exhibit by those that observe her, the dwarfish Quilp puts himself on display. He delights in making sudden appearances that shock or startle, and Dickens speculates that inducing fear may "affor[d] him constitutional delight" (93). Quilp is said to, "at all times" be possessed by a "strong" "taste" for engaging in acts that are "fantastic and monkey-like," such as climbing onto the back of a chair and staring down at those who gape at him (Dickens 124). This urge is partly performative (he makes a spectacle of himself) but also shows Quilp to be animalistic, acted upon by urges akin to those felt by animals in their menageries. ${ }^{20}$ Kelly Hager describes Quilp as an ideal offering for a freak show display, especially since he is paired with his gentle wife. In their marriage Hager sees something "composed of ill-assorted parts (much like the harpy or the minotaur), made up of a man and woman who are so ill-matched that their union is as freakish and aberrant as the mythological creatures they metaphorically resemble" (210). Dickens may have designed the union between Betsy and Daniel Quilp with something more than comedy in mind. Those who managed freak shows (and, in America, dime museums) were "notorious" for controlling "the personal lives of

\footnotetext{
${ }^{18}$ For a discussion of the display of monsters see Ritvo 131-187.

${ }^{19}$ Critics who see The Old Curiosity Shop as an allegory have read Quilp as the symbol of evil to all of Nell's goodness, a symbol of the corruption of a modern, industrialized world where money rules, and a dark throwback to the fairytale (Gibson 178, McCann 175, Boev, Mclean 337).

${ }^{20}$ As with other museual spaces, Dickens was no stranger to animal displays. For a consideration of lions and elephants in Dickens, see Koenigsberger, Kurt. The Novel and the Menagerie: Totality, Englishness, and Empire. Columbus: Ohio State University Press, 2007. Print.
} 
freak performers" (Dennett 80). ${ }^{21}$ Unions between freaks were "fabricated" or "arranged" and "most of these unions were exploited" in order to draw crowds and turn a profit (Dennett 80). Famously, a freak from Worth's Museum advertised for and obtained a wife who "became a freak... in the eyes of the public" because of the marriage, despite her ordinary appearance (Dennett 80). In pairing Betsy with Quilp, Dickens makes the reader wonder what infirmity or lack of judgment could lead this sweet woman to ally herself with the monstrous dwarf.

The other characters sharing space with Daniel Quilp second readings that link him with the grotesque, calling him a "Salamander," (which, in being impervious to fire, aligns Quilp with the Devil), an "evil spirit," and a "represent[ation] and embod[iment]" of "that Evil Power who was so vigorously attacked at Little Bethel” (Dickens 239, 454, 614). Quilp embraces his freakish reputation and even calls himself an ogre (Dickens 614). In Quilp, the wonder and curiosity that should accompany a museum visit are replaced with horror and fear; "the showman's wonders appear as disquieting freaks and amusement... crumbles" (Galletti 46). Interestingly, Mrs. Quilp is described as "fascinated" by her husband, unable to look away, and she believes that his powers of fascination are so vast that, if she were dead, he could seduce anyone he wished (Dickens 81). Even in his sleep, he is able to "transfix" Nell and his eyes remain open as if his constant (museual) acts of observation cannot be stopped for rest. Quilp may transfix or fascinate the reader as well, but his display, whether in text or illustration, conjures up disquieting sensations or even repulsion.

The disquiet aroused in the reader by Quilp is the very thing that makes him essential to the text. In order to effectively exhibit innocence (embodied in the object/character of Little Nell) Dickens must conjure something to threaten this innocence, must provide a contrast in

\footnotetext{
${ }^{21}$ Dennett's arguments center on American dime museums rather than British freak shows. However, the unfortunate treatment of freaks differed little in England during the nineteenth century.
} 
order to illustrate all of Nell's goodness. This type of juxtaposition is museual, as when a healthy diet is contrasted to the "exact specimens" of a criminal one (Black 34). By representing the freakish and the grotesque, Quilp acts as something against which the legitimate educational messages of the museum might be defined; he is that which the museum is not, that which allows the museum to define itself through negation.

Freak shows and menageries were only two among the host of Victorian diversions. Throughout the novel, Quilp also comes to represent these other time-wasting entertainments, such as gambling, while Nell becomes the representative of values sanctioned by the middle class and embodied in rational recreation. The debate over rational recreation in the nineteenth century encompassed many institutions. If a peripheral institution could claim to offer education as well as amusement, it placed itself in the same category as the nineteenth-century museum and encroached on its superiority. Rational recreation, Lynn Barber notes, is something the Victorian middle class was in sore need of and they saw in it a method through which to reform other classes as well (16). ${ }^{22}$ Henry Cole and other champions of the museum believed that exposure to beautiful objects could help viewing subjects to turn away from negative entertainments like the public house and gambling and become educated consumers whose product choices would “improve the economy and produce a British industrial aesthetic" (Kriegel 128, 156-158). ${ }^{23}$ Victorian "advocates of rational recreation" saw in the museum a mechanism which would help its visitors to internalize cultural and governmental values thereby "producing individuals who did not want to besot themselves in ale-houses" (Bennett 20). Museums were also credited with inspiring their visitors to take up industrious hobbies (creating collections of fossils, for example)

\footnotetext{
${ }^{22}$ Barber credits the "seemingly interminable leisure hours" of the Victorian middle and upper classes as one of the elements that helped to popularize natural history, microscope use, visits to zoological gardens (and, one can assume, museums as well) and lecture attendance (16).

${ }^{23}$ Importantly, considering the view that this essay has taken of Nell, museum visitors were often considered to be "teachable vessels," subjects who would learn from the display of objects that confronted their eyes (Kriegel 155)
} 
and beautifying their environments (through parlor room display). The middle class seemed to believe that if one could get visitors inside a museum the mere act of looking would prove transformative.

The rhetoric of rational recreation was not limited to the museum but was also popularly parroted by the institutions it sought to separate itself from. Dickens illuminates this conflict when he notes Mrs. Jarley's fury at being criticized by a school for young ladies. Mrs. Jarley sees her waxworks exhibit as carrying out exactly the same sort of mission as the museum and as the school, with Nell as a central part of the work being done. The waxworks are Nell's second display case and the burden of upholding the institution as a form of rational and moral entertainment falls on her small shoulders. Memorizing each of the moralizing lessons that accompanies each waxwork, Nell then delivers these lessons to Jarleys' visitors (Dickens 285). Nell becomes a sort of audible museum catalogue, and she garners as much admiration and attention as the displays she describes. These moral lessons and the clearly visible innocence of the child giving them are meant to confer on Jarley's all the legitimacy of the museum enterprise.

Though many entertainers and forms of entertainment are shown in The Old Curiosity Shop, it is Mrs. Jarley who makes the clearest bid for the legitimacy associated with the museum. Even before she makes her claims for the waxworks, Dickens's language suggests that the distance between Mrs. Jarley's establishment and the museum proper is not very great. For instance, the handbills in Mrs. Jarley's collections are called "specimens" (Dickens 271). Furthermore, her assessment of and quick employment of Nell suggests that she sees her potential as something that might be put on display. Mrs. Jarley is not alone in her opinion. When the caravan rolls to a stop in town, Nell is soon surrounded by "an admiring group of children, who evidently supposed her to be an important item of the curiosities" (Dickens 280). 
Nell becomes as much an object used in promotion of the waxworks as Slum's handbills and the festoons that decorate the outside of the exhibition. ${ }^{24}$ Nell is sent into the streets as an advertisement, not unlike the giant, circulating mock-ups Thomas Richards describes as a staple of 1840s advertising (48). Like the massive "exaggerated umbrellas, Cheshire cheeses, tubs of butter, and sides of bacon" displayed and circulated by Victorian advertisers, Nell is sent around the streets to draw attention to Jarley's. Unlike the "gigantic commodities" that "inspired laughter and derision" in their viewers, however, Nell is seen as a stamp of goodness upon the establishment which she represents (Richards 49). She embodies the wholesomeness and value associated with the traditional museum.

Confronting gambling, the Punch and Judy show, races, a caravan of dwarves and giants, waxworks, the gypsy camp and elements of the freak show, Dickens draws stark lines between entertainment that offered enjoyment and wicked diversions that weakened body and mind (Dickens 83, 129, 142, 150, 207). ${ }^{25}$ These diversions (and their analogues, the circus, the fair, and the traveling menagerie) "confronted - and affronted" the museum, "form[ing] a part of the surrounding cultural environs from which the museum sought constantly to extricate itself" (Bennett 3). Yet, just as the museum seeks to distinguish between its work and the entertainment delivered by these peripheral institutions, characters like Mrs. Jarley of the waxworks attempt to legitimize certain entertainments as rational, worthy of the middle class patronage of museumgoers. The search for legitimacy compels Mrs. Jarley to make distinctions between rational

\footnotetext{
${ }^{24}$ When she is brought into Jarley's caravan, Nell may be seen as what John Plotz defines as portable property. While Plotz never extends his definition to include individuals, he describes portable property as "dually endowed: ...products of a cash market and, potentially, [belonging to] a highly sentimentalized realm... defined by being anything but marketable" (2). Nell is constantly at the center of debates about cash value: her grandfather seeks to win enough money to care for her, Quilp advances the grandfather money while contemplating making her the second Mrs. Quilp, and Mrs. Jarley employs her for her excellent memory and observable innocence. Nell may also be one of the most sentimentalized creatures in all of literature, a fact testified to by the criticism of Michael Peled Ginsburg, Sue Zemka, Heather Tilley, and Kathryn Sutherland. If Nell is viewed as a museum object, Plotz's theories gain a wider application.

${ }^{25}$ For a discussion of the Punch and Judy show and Victorian pupeteering, see Cleere (49-52).
} 
recreation (aimed at the "classical market,") and "popular taste" of the "General Public" that so "wants stimulating" (Dickens 317). The Old Curiosity Shop embodies the debate affecting the nineteenth-century museum, a debate concerning the nature of rational recreation and whether or not entertainment could coexist with the museum's educational impulses. Just as they represent the public and private faces of the museum (the educational and the grotesque) Nell and Quilp represent opposing sides of this debate. On one side, Nell's “beauty, goodness, and selfsacrifice" are "exaggerated" and even "aggrandized" (Craton 57). Opposing all of this goodness is Quilp, whose "bodily disproportion mirrors a distorted soul" and who "strikes readers as strange, primitive ... bestial and ... 'exotic,' in spite of his Englishness” (Craton 57).

Above, Nell has been shown as an exhibit that instructs the reader in value judgments about innocence, but her native exhibit space of the curiosity shop is quickly abandoned because of the dark machinations of Daniel Quilp. However, Nell's time as a teaching object is not ended once the curiosity shop is left behind. Instead, she is soon being displayed in a new forum, where her "beauty" and "gentle and timid bearing produc[e] quite a sensation" (Dickens 286). As an employee of Mrs. Jarley's waxworks, (where she acts as what Cleere calls "the main attraction") Nell enters a truly museual environment where the values of popular taste and the so-called "classical market" clash over the true cultural worth of the waxworks and, consequently, over the display of Nell (52).

Since a beautiful child loses her advertising appeal by being seen too many times, Mrs. Jarley circulates Nell only occasionally (Dickens 287). When not on display distributing handbills, Nell is inside the waxworks "where she describe[s] the figures every half-hour to the great satisfaction of admiring audiences" (Dickens 287-88). In effect, Nell becomes as much something to see as the waxworks she describes. The sensation she creates when displayed on 
the streets causes viewers to want to go inside the waxworks to see her again. There, she is not merely the guide in the exhibit room; she is one of the exhibits. Her presence is even seen as "reflect[ing] credit on the establishment" (Dickens 307). The innocence first exhibited to the narrator in the weird world of the old curiosity shop is now displayed to a wider audience and the reader is taught to watch with them, and to celebrate Nell's character.

Despite handbills that "prov[e] that wax-work refined the mind, cultivated the taste, and enlarged the sphere of human understanding," Nell's new life as an exhibit piece is not uncontested (Dickens 286). As a museual object that causes controversy, Nell shares the fate of many Victorian and modern day museum exhibits. Victorian curators, for example, worried about the display of classical sculpture and its potential to "incite lewd behavior" (Black 104). Modern museums remain "scenes of contention" where belief systems and politics may meet and clash (Zolberg 70). Today both curators and museum visitors may question museum processes, especially the museum's ability to "reproduce other cultures for the visual consumption of visitors" (Riegel 83). Oral histories, like those given by tour guides, may even contradict items visually on display (Gable 178, 185-187).

Though neither political debate nor classical sculpture causes comment at Jarley's, the "bright-eyed girl" sent around to "dispers[e] handbills" does not escape the controversy that so often attends museum display (Dickens 286). At Miss Monflather's Boarding and Day Establishment, Nell is once again a prime exhibit, "the centre on which all eyes were fixed," but the stares that greet her are not the admiring ones she has been accustomed to as part of Mrs. Jarley's exhibit (308). In accosting Nell for her wickedness in being a "wax-work child," (which connects her, again, to objects) Miss Monflathers argues that the waxworks belong to popular taste and have no place in the lives of the young ladies at her boarding school. 
More interesting even than Miss Monflathers's indictment of popular entertainments is the museual language that creeps into her conversation with Nell. She tells the child, in words that might have originated in the Crystal Palace Exhibition Illustrated Catalogue that her "infant powers" should be spent "assisting" the "manufactures" of Britain and contemplating the steam engine (Dickens 308). Miss Monflathers' speech demonstrates a typical Victorian attitude: an inherent trust in the powers of industry as an uplifting force. ${ }^{26}$ This new context transforms Nell. Previously she has been an exhibit of innocence, but, to the ladies of the school, she becomes a symbol of vice. Once more, Nell is held up to teach a lesson. This time, Nell is pointed to as an example of what not to do. A common nineteenth century museum practice that operated on these same principles "contrasted an athlete's arm with a sedentary person's" or "the stomach of a healthy person with that of a drunkard" (Black 34). By displaying dichotomies (healthy and unhealthy, beautiful and grotesque) the museum sought to instill proper behavior in its viewers. In displaying Nell beside Quilp, Dickens is doing the same.

While the natural history museum in particular did serve to provide rational recreation for working class Victorians by inspiring them to keep collections of their own or introducing them to advances in health or hygiene, the idea of educational uplift forgets or intentionally ignores (as does Miss Monflathers) the physical realities of the working class (errors that will be compounded by institutions like the Crystal Palace which will be exhibited in chapter two). ${ }^{27}$ Nell has not entered into her career as a wax-work child because of any inherent belief about such entertainments. She joined Mrs. Jarley’s caravan because she was hungry and tired. Nell

\footnotetext{
26 Though Dickens has chosen to embody this belief in the words of a single character, it was a popular (though ultimately unsuccessful) museum belief throughout Victorian Britain. Museums as institutions were meant to be ranged against the unsavory entertainments of the working classes (the gambling of Nell's grandfather, for example) and purposefully kept late hours in order to win workers away from the public house. The Great Exhibition, which will be the focus of the second chapter, was also meant to instill national pride in British manufacture and industry, like the steam engine Miss Monflathers wants Nell to spend her time contemplating.

${ }^{27}$ Barbara J. Black discusses the way that museums competed with public houses: it "offered evening hours and specially targeted exhibits" purposely constructed to lure holiday-goers away from drink (33).
} 
becomes an exhibit piece for much the same reason that the dwarves and giants of Curiosity Shop's earlier chapters do; at Jarley's, she is fed, cared for, and provided with a safe and comfortable place to sleep. The desires of those with popular taste do far more to contribute to her comfort than any lofty ideas about rational recreation.

Ideas of rational recreation also enter into Mrs. Jarley's advertising methods and her descriptions of her work are decidedly museual. She claims that the waxworks instill their audiences with a sense of British history and national pride (provided, of course, that they are costumed properly) - claims also made at the Great Exhibition. At the closing of the Exhibition, for example, The Times notes "feelings of gratified curiosity, of national pride and of enthusiasm at the public homage paid to industrial pursuits" (qtd. in Fay 126). While it is only wished by Miss Monflathers that Nell "pay homage to industrial pursuits," the quotation otherwise fits the work of the wax museum and would likely have been accepted by Mrs. Jarley if offered by Mr. Slum as advertising. Her waxworks are also patronized by royals. While, to a modern reader, this might simply sound like a gimmick to gain more admissions money, it is also a link between Jarley's and the museum enterprise in Britain, which was often funded, sponsored, or donated to by the nobility. A royal stamp of approval could do wonders for a museual enterprise.

Besides following the museum's mission of rational recreation, Jarley's also possesses strong ties to the natural history museum. Both seek to embody life in lifelessness, through taxidermy or wax sculpture. Mrs. Jarley comments explicitly on the ways in which waxwork and life sometimes overlap by noting, "I won't go so far to say, that, as it is, I've seen a waxwork quite like life, but I've certainly seen some life that was exactly like waxwork" (Dickens 272). The diminishing distance between objects (whether on display in shop windows or in the museum) and subjects was a subject of increasing anxiety for Victorians, who sometimes found 
it difficult to separate themselves from their things, especially abroad (Plotz 45-50). Objects seemed to take on lives of their own and objects like the waxworks, which were made to resemble people, might have been acute triggers for unease, as they are for Nell (Dickens 28889). The space used by Jarley also sounds museual. She highlights the "select" nature of the "company" and the "assembly rooms, town-halls, large rooms... auction galleries" that have housed her waxy company (Dickens 274). The museum, like Mrs. Jarley, would be quick to separate itself from the "open air wagrancy [sic]" associated with the fair, the circus, and the freak show.

Quilp, in contrast, is connected to the popular entertainments against which the museum (and Jarleys) sought to distinguish itself. Even without his fantastical antics (discussed above) Quilp's sheer physical appearance would qualify him for inclusion in a freak show, a type of entertainment that clearly was not a form of rational recreation. ${ }^{28}$ Dickens provides a glimpse of such an environment during the discussion at the inn. There, the proprietors of freakery discuss the value of dwarves and giants, how often they are to be displayed, and what is to be done with them in their old age. By including this section, Dickens looks back to Quilp's entry into the text, where he is marked as "so low in stature as to be quite a $d w a r f$, though his head and face were large enough for the body of a giant" (65, my emphasis). Both dwarves and giants were popular freak show exhibits and Victorian London had "no lack of giants, whether measured horizontally or vertically" while "dwarfs were associated with exotic freak show... roles" and were a

\footnotetext{
${ }^{28}$ Quilp can also be linked to the natural history museum. He, like it, is associated with the consumption of bodies... though his destruction of them does not end in display. Cohen, for instance, sees Dickens's use of the keyhole as a metaphor for the threat of Quilp's "consuming" mouth (32). On this subject, Quilp is even driven to make the comment, "I don't eat babies," (Dickens 223). That he feels the need to say otherwise suggests that something in his appearance that marks him as cannibalistic (an argument made by David below). Furthermore, Quilp is even credited with an understanding of natural history! After comparing Sampson to a tortoise and a rhinoceros, Sampson exclaims, "His acquaintance with Natural History too is surprising" (Dickens 478). Hennelly reads in this exchange a "Rableisian link between natural history and the carnivalseque" as Sampson goes on to conflate "Buffon" (the French naturalist Georges-Louise Leclerc, Comte de Buffon) and "buffoon" (100, Dickens 478).
} 
common freak show attraction (Altick 253, Bogdan 175). All the connotations of the freak show enter the text with the dwarf-giant form of Quilp. Furthermore, Quilp's contradictory nature makes him worthy of the reader's observation; he is small enough to appear suddenly, seemingly out of nowhere, but powerful enough to cow individuals larger and worthier than himself. Indeed, when told to fight someone his own size, Quilp asks, "Where is there one of my size?" (87). As the strange merger of dwarf and giant that he is, he is correct.

The freak show aimed to satisfy curiosity, incite sensation, and arouse pleasant feelings of fear. Quilp is able to be "perfectly goblin-like" when he chooses and, though all of the enjoyment is on his side, he does engage in horrible performances, usually to terrify his wife (Dickens 81). These consist of making faces taken from the world of nightmares and exaggerating his ugliness with "unexpected" motions designed to make Mrs. Quilp cry out in fear (Dickens 82). At the breakfast table, he "perform[s] so many horrifying and uncommon acts" that his mother-in-law and wife are ""nearly frightened out of their wits and began to doubt if he were really a human creature" (Dickens 86 ). This description might easily apply to a freak show, where the performers were displayed in order to create such sensations.

There are several Quilpian exhibits throughout The Old Curiosity Shop, but the horror of him comes home in chapter twenty-seven, where Nell's dreams "somehow connected [him] with the wax-work"; in her dreams Quilp is "Mrs. Jarley and the wax-work too, or [is] himself, Mrs. Jarley, wax-work and a barrel organ all in one, and yet not exactly any of them either" (279). While this passage can be read as nothing more than a nightmare that shifts shape, it can also show that, to Nell's mind, there is a fitness to Quilp being exhibited. He is horrible because he is a dwarf/giant; his small size and massive cunning may allow him to enter any exhibit at any time. Quilp is an object that threatens, that cannot be shut out. What is truly frightening about 
Quilp is that one never knows what he might be inside; the other characters in the text seem to fear that he can even come through keyholes. Nell imagines his eyes peering through the waxy gaze of the mannequins, watching her in the vulnerable state of sleep (289).

Nell's fear of an ever-vigilant Quilp connects his character even more firmly with museum. As a hyper-observant character, bordering on voyeuristic, Quilp takes on the activities most associated with the museum experience: watching and being watched. Dickens spends over a paragraph describing the antagonist's features and finishes by stating that, "[t]here was ample time to note these particulars... for some moments elapsed before any one broke [the] silence" (Dickens 66). Quilp's appearance makes everyone stop and stare. Furthermore, he is not a passive object of study. As they stare at him, he "glance[s] keenly at all present" (Dickens 66). He is shown to have a look that "comprehend[s] every object within his range of vision, no matter how small or trivial" (Dickens 70). He peers through keyholes and watches Mrs. Jiniwin even as she looks into the looking glass, making it a display space that he conquers (Dickens 85).

The boy who serves Quilp at the wharf knows to be wary of the counting-house's sole window, for he assumes that Quilp will be looking out of it; he has internalized the idea of Quilp as an ever-watching presence, a Foucaultian surveillance system (Dickens 88 ). Quilp becomes a sort of panopticon. Even tiny details do not elude him. When Nell and her grandfather flee, his "keen eye" notices a few missing articles of clothing and attributes their removal to the clever Nell, "knowing the old man's weak state of mind" (Dickens 158). The power of his eye is so constant and steady that he is able to prevent Mrs. Jiniwin from even sweetening her tea; he stops any movement of her hand to the sugar bowl with a look (243). If Nell is Dickens's ultimate museum piece, Quilp with his "constant vigilance" is the twisted and perverse representative of 
the singular, proper viewpoint that Victorian museums sought to instruct their viewers in (Dickens 243).

Not only does Quilp embody a warped version of the museum's obsession with sight, he may also be seen as a perversion of the museum's collecting spirit. In a guide prepared to train curators, Burcaw describes the surprise that individuals sometimes feel when confronted with the idea of a theory of collecting. He then explains that such a theory must operate in the museum, as no museum can collect "all objects that exist"; "collecting has to be selective" (57). While Quilp's main interest is in collecting money in the form of rents or gambling markers, his personal museum space, “Quilp's Wharf," reveals him to be an indiscriminate collector (Dickens 73). The Wharf is home to "a few fragments of rusty anchors; several large iron rings; some piles of rotten wood; and two or three heaps of old sheet copper, crumpled, cracked, and battered" (Dickens 73). None of these items can be of any use to Quilp (except as a sinister labyrinth to trap or injure unwary visitors) but they are part of the hoarded heap he rules over. ${ }^{29}$ This "goldhoarding troll" exhibits the same spirit when he takes over the curiosity shop (Branwen 136, Dickens 562). Coming into possession of its miscellaneous treasures, he swiftly takes a "minute inventory" to determine what has passed into his hands (141).

Quilp may also be connected to the imperial exhibits that happened at the end of the nineteenth century. Like the freak show, these were peripheral institutions from which the museum sought to separate itself. Shows featuring human display (human zoos, imperial exhibits, and freak shows) "reached their peak in terms of scale, commercial success, and public access under the aegis of the international trade ... that followed in the wake of the Great

\footnotetext{
${ }^{29}$ The strangest thing that Quilp collects is the ship's figurehead of chapter 62. Dickens guides the reader through a curiosity cabinet of comparisons when he describes it as "a goblin or hideous idol," "distinguished merman" and a "great sea-monster" (Dickens 564). In the object of the figurehead, Quilp sees a representation of Kit and he sets about maiming it as if his blows will have a sort of voodoo doll effect, resulting in injury in the "real" Kit (Dickens 566).
} 
Exhibition," making one of the most influential museual spaces the impetus for the very institutions it despaired of (Qureshi 3). Nadja Durbach further identifies London as the "Capital of Exotic Exhibitions" and notes that "between 1830 and 1860," "Londoners developed a seemingly insatiable appetite for 'monsters,' 'human oddities,' lusus naturae, 'prodigies,' 'novelties' and 'freaks" (81). These monsters and freaks were often imported from the edges of the Empire and advertised as freaks as much for their foreignness as for any bodily anomaly.

Daniel Quilp is connected to these imperial exhibits through his appearance and the novel's continual suggestions that he is foreign. His monkey-like antics link him to imperial advertisements which often presented natives in such poses (McClintock 211, 214). His stature suggests deformity and devolution, traits that racial science would have relegated to natives rather than healthy, superior Europeans. The constant references to him as "dwarf" suggest that he even belongs to another species. Even his association with the freak show, an enterprise that became increasingly imperial at the end of the century, sets Quill apart from the other characters of Curiosity Shop. As an unsavory character, he is never marked as unquestionably British. Instead, he is shown "seated like an African chief" as he orders Mrs. Quilp and Mr. Brass to empty the curiosity shop in the wake of Nell's departure (Dickens 160). David makes an excellent case for Quilp's non-English status based on his physical appearance. Citing his dark eyes, dark hair, discolored skin and fangs," David marks Quilp as a "symbolic cannibal roaming the domestic spaces of early Victorian Britain in search of food" (127). Quilp is the devouring force that threatens Nell's ever-displayed body.

Though Quilp stands out even among Dickens' most horrifying creations, the distance between the grotesque exhibit of the dwarf and the young girl whose dreams he haunts is not as great as would initially appear. Though placed in seeming conflict, Nell and Quilp are linked as 
representatives of museual aspects... and Quilp may not be the most horrifying of the two.

Above, I have discussed the methods used in preparing a specimen for display. Such preparation ultimately creates value (a teaching tool) out of death, the result of a vampiric economy that underpins the taxidermy and specimen-filled halls of the natural history museum, but which is rarely acknowledged. Ironically, specimens are often chosen for their lifelike appearance and used to illustrate life narratives about population or evolution. The character of little Nell participates in this same economy. ${ }^{30}$

This connection may be seen when Nell travels with the waxworks caravan. ${ }^{31}$ There, she sleeps with the wax figures arranged around her, but she grows to fear their "death-like faces" and to feel "a kind of terror for them for their own sakes" (Dickens 289). Some of this fear must arise from the contrast between their lifelessness and their lifelike appearance, for they "loo[k] so like living creatures, and yet so unlike in their grim stillness and silence" (289). Nell sleeps, as she will by the conclusion of the book, in a chamber of death. Surrounding her with these lifelike, lifeless bodies, Dickens foreshadows her purpose (to teach through sight as the models do) and her fate as an object caught up in the vampiric economy of the museum.

Nell is remembered, both lovingly and with scorn, as a dead girl. The Old Curiosity Shop owes its value (contested as it may be) to the child figure at the text's end, stripped of life and put on display for Dickens's massive audience. American readers awaited the ships from England that carried the book's final installments; standing on the docks, they cried out for news of Nell and to find out whether or not she yet "lived" (Boev). Yet Nell has never lived. She is

\footnotetext{
${ }^{30}$ This economy will be more thoroughly detailed in chapter three, where it is examined in operation in Our Mutual Friend.

31 Though not a proper museum, Jarley's uses figures which are bodily representations of dead people, the exhibition of which allows Mrs. Jarley to "chin[k] silver moneys from noon til night" (319). The death-echoing figurine results in capital. That she can rearrange the exhibits (appropriating one exhibit to be remade into another) echoes the way that natural history museums disassemble and remake their exhibits, all on the foundation of dead bodies. Such a foundation is necessary to the museum enterprise; "through acts of collecting," "the other" is supplanted by the collector and the subjectivity of the collector is affirmed (Black 22).
} 
removed from any possible version of that state her readers understand as life. Still, the display of her lifeless body (which, having never lived, was always lifeless) brought readers to tears. ${ }^{32}$ Only in death could she be held up and memorialized as a symbol of "goodness," a model of lasting value (McParland 19). This is the very economy of the natural history museum. It is, like all of the horror and the violence represented by Daniel Quilp, grotesque.

Only in death can objects be stilled and studied, and it is in death that Nell's value becomes the most clear. Everything about her can be put on display and admired. ${ }^{33}$ The complaints that Nell never voiced and the pain that she silently suffered become clear upon her death in the display of her worn shoes. Her grandfather relates, "You see where the little feet were bare upon the ground. They told me, afterwards, that the stones had cut and bruised them. She never told me that. ... she walked behind me... that I might not see how lame she was" (649). In life, Nell was able to hide her afflictions and to control how she was seen, at least to some extent.

In death, her representation falls to others, especially illustrator George Cattermole. His last earthly illustration of Nell is filled with light and emphasizes sacred objects like the Madonna carved into the headboard of her bed. Such an illustration places Nell on the side of the angels and tells the reader to align him or herself with the principles embodied in Nell. These principles are universal, meant to be applied to "old men... grandmothers... the deaf, the blind,

\footnotetext{
${ }^{32}$ McCann argues that this must be so because, in all of her lifelessness, what Nell represents is the reality of a child, "flesh and blood" (192). Today, readers disagree over the value of Nell's body. This disagreement may have something museual about it. Modern viewers of Walter Potter's "taxidermic tableaux" are disturbed by the "immediacy and presence" of the manipulated and carefully posed animal bodies that, despite one's knowledge to the contrary, appear "seemingly alive" (Creaney 7, 8). Does the modern reader's rejection of Nell attempt to sidestep the disturbing display of the dead girl's body for the same reason? Do we, with Oscar Wilde, laugh at her death because to otherwise engage with it would conjure up the same eeriness attributed to Potter's museum works? ${ }^{33}$ McParland demonstrates that this was true outside of the world of the text as well as on the printed page. In a world she never occupied, Nell is "suggested for a figure in a wax museum" (19). Nell also appears in one of the only two known statues of Dickens, staring up forever at her creator. Interestingly, this version of Nell actually made it into a museual space, put on display at the World's Columbian Exposition of 1892 ("Dickens and Little Nell" 12). For a discussion of the importance of this statue, see Sroka 184-185.
} 
the lame, the palsied, the living dead [as we all are] in many shapes and forms" (Dickens 657658). The audience that gathers around Nell's grave is representative of everyone; they are the crowd that was welcomed into the museum to be instructed and improved.

Their remembrances of Nell highlight the lessons the reader is to take away. They recall her in attitudes of thoughtfulness and remember her possessing a bravery that seemed at odds with her slight form. They concur that "she had walked and talked with angels" (Dickens 658). By stilling her body and causing her chest to no longer rise and fall, Dickens has created a teaching tool. Buzard illustrates this when he notes that the narrator of The Old Curiosity Shop “imagines a vibrant growth economy of goodness rooted in the fertile soil of Little Nell” (203). Just as the grand narratives of progress put forth by the museum are built on the display of dead humans and animals, morality, in the world of Dickens, is built on the body of a dead girl.

In death, Nell's features take on the "majesty" of the angels with whom she may have communed; her cares are smoothed away so that she becomes more marble than flesh (654). She is an object to be admired and praised, and even envied for her spirit's residence in heaven (654). In the end, Nell is not a person or even a character, but an object and an object lesson that is to be forever remembered and learned from, as the objects that clutter museum cabinets are to be used to increase one's knowledge. Dickens devotes an entire paragraph specifically to Nell's lesson:

"Oh! it is hard to take to hear the lesson that such deaths will teach, but let no man reject it, for it is one that all must learn, and it is a mighty, universal Truth. When Death strikes down the innocent and young, for every fragile form from which he lets the panting spirit free, a hundred virtues rise, in shapes of mercy, charity, and love, to walk the world, and bless it. Of every tear that sorrowing mortals shed on such green graves, some good is 
born, some gentler nature comes. In the Destroyer's steps, there springs up bright creations that defy his power, and his dark path becomes a way of light to heaven"

As a dead child, Nell can teach the lessons of love and kindness that she embodied in life. Only in death can they be easily read. It is proper, then, that it is for her death that Nell is most remembered. Nor is her deathbed scene the last museual moment of the text. Once Nell's body is safely interred, her route from the curiosity shop to the church becomes a sort of tourist road or pilgrim's walk as the "single gentleman" "delight[s] to travel" the roads that she walked (Dickens 670). He pauses on his road in the places that she paused and shares in her joys and sorrows just as the museum visitor will stand before a glass case and wonder about the lives of the specimens within, imagining what strange twist of fate brought them to dwell (but not to live!) forever behind glass (Dickens 670).

Nell's lesson outlives her, just as the lessons that accompany the bones and pelts displayed in the natural history museum outlive those beasts to which they once belonged. Eternally instructive, Nell can be read as the face of the museum that the museum enterprise turns toward the public, the face that it wants to be seen. Quilp, eternally covetous, is the dark side of the museum enterprise, its destructive power, the elements it shares with the freak show, the imperial exhibit, and the human zoo. This hidden face is often overlooked by museum visitors, even today. An acknowledgment that the museum is built upon dual foundations of education and the grotesque, allows for a richer viewing of this important Victorian institution. Likewise, a museual reading of The Old Curiosity Shop highlights aspects of the text overlooked 
by other scholars and provides a richer understanding of Victorian entertainment, rational recreation, and museum culture. 


\section{Chapter Two: Crystal Fragments: Museum Methods at The Great Exhibition, in London}

\section{Labour and the London Poor and in 1851}

Though not a museum proper, the Great Exhibition of the Works of Industry of All Nations introduced thousands of visitors to the museum's methods of organization, observation, catalogue, and taxonomy. A key event in museum culture, the Great Exhibition is also the parent institution of some of Britain's most famous museums, including the Victoria and Albert. Described as "perhaps the most influential representative body of the nineteenth century," the Crystal Palace altered Victorian notions about commodities, advertising, and even national status (Richards 17). Victorian audiences expected the great, crystalline showcase to produce changes in attitudes about art and manufacture, as well as literal changes in methods and types of production. Alongside these things, the Crystal Palace Exhibition also produced bewilderment in its audiences as they attempted to comprehend and classify its contents. This chapter will examine the Crystal Palace as an example of Michel Foucault's heteroclite, a site of "disorder in which fragments of a large number of possible orders glitter separately in the dimension, without law," and discuss the use of guidebooks and museum catalogues to ameliorate visitor anxiety and codify and contain the wonders of the Crystal Palace (xvii). These attempts at containment will also be shown to appear in Henry Mayhew's London Labour and the London Poor where the journalist attempts to discipline and order the world of the poor in the same way that audiences used catalogue and taxonomy to discipline and order the world of the Crystal Palace. Finally, this chapter will turn to Mayhew's little read 1851, where the museum world created by the Great Exhibition is exaggerated and mocked and where the museum begins to discipline individuals far more than museum visitors can discipline the contents of the museum. The transfer of museual 
methods of discipline to the social sphere in London Labour and to the world of the novel in 1851 highlights the reach of the museum's influence in the nineteenth century.

Intended to provide "a true test and a living picture of the point of development at which the whole of mankind [had] arrived," the Great Exhibition was an experiment in classification as much as it was a spectacle, a celebration, or a competition between nations (Martin 208). Originally, the goods and treasures piled within the Crystal Palace were meant to be arranged within the four major categories of raw materials, machinery, manufactures, and fine arts. The categories mimic the industrial process whereby raw materials may be transformed into (or by) machinery, yielding, at the highest level, works of artistic beauty. However, the practical arrangement of the Exhibition's floor plan led goods to be categorized "first by nationality and only secondarily by function," with the British Empire "occupying the lion's share of the Crystal Palace" (Gillooly 27). In arranging the floor plan "into a miniature tour of the world," the organizers of the Exhibition threatened the very classificatory system they set in place (Buzard 44). Furthermore, "the slow arrival of exhibits and exhibit information" forced organizers to group items as they arrived, a situation which favored groupings by "geographical location and political status" (Purbrick 55). The "living picture" viewers came away with was ultimately one of British superiority, a sort of nationally-based taxonomy in which the lion truly ruled over all of the other beasts. ${ }^{34}$

Despite the taxonomies and floor plans, visitors could easily become lost, dazzled, or taken aback by the manufactured jungle of commodities houses inside of the Crystal Palace. The site on which all of the wonders of the modern world are gathered becomes the site of the heteroclite, a site of "disorder in which fragments of a large number of possible orders glitter

\footnotetext{
${ }^{34}$ See Richards 32-33 for a discussion of the compromised classification system .
} 
separately in the dimension, without law," (Foucault xiv). ${ }^{35}$ This disorder owed much to the organizers' abandonment of the original classifying scheme. With this scheme removed, the visitors were left to make meanings of their own. Therefore, each visitor to the Crystal Palace contributed to the "number of possible orders" of meaning as he or she combined images and meanings to create personal taxonomies.

However interesting they might have been, these personal taxonomies (these fragments) did not substitute for an official sense of order, a lack which may be perceived in visitor responses to the Great Exhibition. In a travel diary, William A. Drew remarked on "the infinite variety of goods, wares, specimens of fine arts, skill, taste, and \&c.," suggesting the difficulty of putting the Palace's sights into words (207). Queen Victoria herself related exhaustion, writing that she was "really bewildered by the myriads of beautiful and wonderful things, which now quite dazzle one's eyes." She later admitted to being awed at "the vastness of the building, with all its decorations and exhibits" (Fay 45, 47). Dickens claimed to find "too much" in the Exhibition, uncertain, in the end "if [he] had seen anything but the fountain and perhaps the Amazon" (Fay 73). Responses like these refute the museum precept that to see is to know and enforce the need for an ordered way in which to encounter the wonders of the exhibition (Hibbard 153). Without a taxonomic framework, a visitor might see a great deal but fail to absorb the sights or to connect them in any meaningful narrative. ${ }^{36}$ Meaning "glitters" in the distance like the walls of the Palace, but remains elusive, disconnected, and impossible to pin down.

\footnotetext{
${ }^{35}$ While Foucault likely was not thinking of the Crystal Palace during the composition of The Order of Things, the use of the word "glitter" is especially appropriate in that fairy world of glass.

${ }^{36}$ Michelle Henning describes this as a "crisis of knowledge" and notes the measures museums have taken to correct the problem of "confused, disoriented, and distracted spectators": "... they [museums] reorganized displays into clean, uncluttered exhibitions, marshalling objects into more coherent narratives..." (308)
} 
Fortunately for visitors to the Crystal Palace, the Great Exhibition provided an exhilarating economic opportunity for publishers and printers, who churned out guidebooks to the city, guides to transportation and lodging, and museum catalogues in huge numbers. ${ }^{37} \mathrm{~A}$ single publisher produced four separate guides to the city of London in 1851 alone (Bellon 311).These publications came in a wide range, from The Crystal Palace Penny Guide with its twenty-two pages of advertisements (out of a total of sixty-four pages) to the four volume Official Catalogue of the Great Exhibition of the Works of Industry of all Nations, 1851, published by the Royal Commission. The latter was much too bulky for any spectator to carry it to the Exhibition for consultation; it served, instead, as a take-home museum that could be browsed and acted more as a commemorative publication than as a guide. Sixpenny guides and clothbound works with titles like How to Enjoy London during the Great Exhibition were also available for those planning to visit the Exhibition (Bellon 311). Richards describes the problems associated with the guidebooks produced by the Planning Commission, noting that: "the short one offered descriptions so terse as to be unintelligible, while ... the long one was too heavy to be carried around the Exhibition" (27). Despite their limitations, the guidebooks actively sought to improve visitor experience and to combat the visual onslaught produced by the massed commodities inside of the jewel-box of the Crystal Palace. Out of the "site of disorder" each guidebook sought to produce a single, correct interpretation. For instance, Hunt's Hand-Book to the Official Catalogues emphasizes a "general desire" to "provide some concise description of the Exhibition - some guide" and to "afford that interpretation which appeared to be required" (volume 1, vi). That interpretation should be required and should be sought outside of the objects

\footnotetext{
37 This museum book mania is captured in 1851 when Mayhew notes that "Bradshaw's Railway Guide had swelled into an encyclopedia" and "ATLASES' were being made extra strong so that they might be able to bear the whole world on top of them;" about to be swarmed by exhibition-goers, London prepares marshalling museum know-how and creating catalogues (Mayhew 4).
} 
proper indicates that the Exhibition was not instantly and readily readable. The great and glassy jewel lid conceived by Joseph Paxton seemed capable of closing in the entire world, but it did not offer a cohesive narrative of what it contained; because of this, the concept of the Crystal Palace is fragmented from the start.

Other catalogues supported the idea that the Exhibition was difficult to read. Because many orders of meaning were possible, it was difficult for viewers to determine if they had hit upon the correct one. The "object" of Routledge's Guide was "to supply an obvious deficiency in the existing catalogues, namely the whereabouts of some of the most striking and interesting articles exhibited" and to "relieve the bewilderment" experienced by the Palace's visitors (v, vi). Such a claim challenges both the set up of the Exhibition and the arrangement of other publications and holds out Routledge's Guide as the authoritative source. The Penny Guide offered a "ready Handbook" for visitors too busy for a detailed examination of the Exhibition and contained "a list" of a "series of handbooks" for those interested in a more detailed study (3). Tallis's four volume History and Description of the Crystal Palace offered engravings of "superior excellence" intended to provide "pleasing remembrances" of objects seen during one's visit to the Exhibition (iii, iv). The Official Catalogue (four volumes) echoed this in its hopes "to serve as a lasting memorial of the splendid collection of which it professes to be the exponent" (vi). Finally, The Crystal Palace Exhibition Illustrated Catalogue strove "to include, as far as possible, all such as might gratify or instruct; and thus to supply sources of after-education," allowing the benefits of the exhibition to be reaped even after one had departed the halls of glass (v). Guidebooks helped transform the spectacle of the Exhibition into an opportunity for rational recreation even as they helped to stabilize the contents of the Palace and to forestall the heteroclitean chaos that they seemed to represent. 
In order to undo the Exhibition's overwhelming effects, the catalogues often sought clarity through limitation. Only the Official Illustrated Catalogue presented every item on display; the others used significant items as touchstones, representations that stood in for a huge number of objects that were not described. Meaning-making was further facilitated by the organizational choices of guidebook editors, the majority of which followed a particular pattern in the arrangement of their texts. ${ }^{38}$ The two-volume Hunt's Handbook serves as an example of catalogue organization. It begins with a floor plan and an introduction that outlines the catalogue's philosophy. Hunt is quick to assure readers that items have been chosen not because they "are superior to others" but because the Exhibition contains "a variety and vastness to which we are unused" (v). The text then escorts the reader from the Transept (1) up the West Main Avenue (5), through the item featured outside of the building (17-21) and then through the interior. The second volume continues this pattern, devoting the final section first to "Colonies and Dependencies" and then to the Foreign Department (710). The emphasis, as with the floor plan inside of the Palace, is placed upon British items, regardless of class. Whatever the organizational method chosen, each catalogue was a discreet method (its binding creating a literal boundary) for limiting "the large number of possible orders" contained in the heteroclite world of the Crystal Palace. Each catalogue subjects the objects to an order and puts a halt to the popular illusion that "the commodities in the Crystal Palace appeared to be expanding profligately in every direction possible" (Richards 27). Within the world of the guidebook, these commodities existed in limited, numbered, and knowable quantities.

Besides sharing organizational principles, the catalogues also shared methods which can be traced back to the nineteenth-century museum. The museual methods most favored by these

\footnotetext{
${ }^{38}$ Obviously, economic concerns would have been a factor in the creation of the handbooks and guidebooks. Therefore, the Penny Guide is less inclusive than the multivolume works.
} 
guidebooks are cataloguing, the creation of taxonomies, and evaluation. These three methods are central organizing devices in the natural history museum, both in the nineteenth century and today. Cataloguing reveals the contents of the museum, taxonomy reveals the relationship of specimens to one another, and evaluation, often appearing in explanatory plaques, explains either the "lesson" the museum-goer should take from a particular exhibit or the rationale behind including such an object or exhibit in the wider collection. In transferring these devices out of the museum and into print, guidebook editors attested to the cultural capital and influence of the museum as a model to make sense of the world.

As one of these models, the museual idea of catalogue cannot be reduced to the mere act of listing. As a particular taxonomic process the act of cataloguing can also refer to the act of collecting and arranging objects within a larger exhibit. Many natural history museums today have a representative catalogue on the floor (a hall of mammals, for example) which is only an excerpt from a larger "hidden" catalogue which exists in roll-top drawers and specimen boxes. ${ }^{39}$ A museum may display some of its best treasures, but it is rare for any museual catalogue to contain only one of a particular specimen. This abundance, the vastness of the collecting enterprise, is the impetus for cataloguing and collecting and was certainly not limited to the Victorian museum.

During "the heyday of natural history," museual hobbies were undertaken by vast numbers of Victorians (Barber). Victorians took on museual labor as they created rock collections, parlor cabinets of curiosities, salt and freshwater aquariums, fern cases, insect collections, and flower pressings. Collection was so widespread that weekend newspaper articles

\footnotetext{
${ }^{39}$ The problem of overabundance or "over" collection is so well known to museum scholars that the actively caution curators against it. For example, the Handbook for Museums states in bold letters that are set off from the surrounding paragraphs: "Museums should not, except in very exceptional circumstances, acquire material that the museum is unlikely to able to catalogue, conserve, store, or exhibit... in a proper manner" (Dean 93).
} 
addressed its importance. For example, The Saturday Magazine ran several features regarding the creation of a domestic museum. In one of these, concerns about cataloguing arise. While the curator of a private, domestic collection is discouraged from over-labeling items which were "chosen" for "his own intellectual use" and thus are "too familiar to him to require labels," public museums are urged to label and classify items in order that "the humblest visitor, whether possessed of books or not [could] identify" the items on display "as a means of pleasure and instruction" (229). In short, a museum should know what it possesses and be able to make this information easily known to a visitor. Where such information was perceived to be lacking, as in the case of the Great Exhibition, catalogues and guidebooks looked to fill the void by creating lists and descriptions of the items on display.

These lists and descriptions formed museual catalogues that existed in one of two formats. The first is exemplified by the Illustrated Catalogue, which devotes much of each page to engravings, the high number of which is evidence "that neither cost nor labor has been spared" in its creation (v). These engravings are then paired with a few lines of text which identify the object, its maker, and include some form of evaluation. For example, the half-page engraving of a statue of Godfrey of Bouillon includes this description: "We should most assuredly have omitted one of the greatest features of the Exhibition had we neglected to introduce into our Catalogue the colossal statue of the renowned crusader, GODFREY OF BOUILLON, modeled by M. SIMONIS, of Brussels. It is a work conceived in a noble spirit, and admirably carried out" (185). The second method of cataloguing relies much more heavily on text and may or may not include an engraving of the object described. The Official Catalogue eschews engravings, for example, and its inclusion of every single object in the Exhibition renders the descriptions quite 
short. Under the class heading of "LEATHER, SADDLERY, BOOTS, AND SHOES," for example, one finds catalogue entries like these:

“BEVINGTONS \& SONS, Neckinger Mill, Bermondsey,

Manufacturers.

Goat, sheep, seal, kid, and lamb skins, in the manufactured state.

Goat, seal, sheep, and calf skins manufactured into morocco, roans, skivers, and enamelled [sic] leather, for furniture, bookbinding, and shoe leather.

Kid, lamb, Cape sheep, and calf skins (alum leather), manufactured for gloves, shoes, and shoe binding.

Specimens of leather, with varieties in tanning and leather dressing."

The editor then adds this explanatory note, "Leather, such as that used for boots and shoes, is strictly a chemical product. The skins of a variety of animals are employed in the preparation of this article of universal use. The preparation of most varieties of leather consists essentially in the formation of a chemical compound, of the gelatine [sic] of the skin, and of a chemical principle called tannin, contained in the liquid used. Alum leather differs from ordinary leather in its properties and composition." (volume 2,518$).{ }^{40}$

The reader can imagine the difficulty of matching this particular entry to the goods on display, to say nothing of the labor involved in perusing four volumes of such lists. Other catalogues endeavored to make their entries more interesting and to make sure that readers could connect the item catalogued to the physical item on display. For this reason, large, flashy,

\footnotetext{
40 The spacing and alignment used here is meant to replicate the appearance of the text in the catalogue. Entries appear on both sides of the page in columns.
} 
expensive, and significant items often feature in the catalogues alongside samples of carpet or lists of raw materials.

The creation of lists or catalogues to organize data and make it accessible is not a purely Victorian preoccupation, but the Victorian connection between the catalogue and the museum

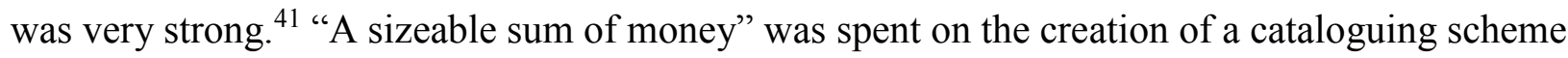
for the British Museum, for example, though it did not ultimately yield a catalogue (Strout 267). Attended by six million people, the Great Exhibition helped make the catalogue form a familiar one to the Victorian reading public. When describing the Exhibition in the novel 1851, Henry Mayhew attests to this familiarity when he notes that most viewers "have catalogues or small guide-books in their hands," and that they "gaze" in an "earnest manner" at the assembled objects before "refer[ing]" to the books (160). His example shows that the museum-going public has learned how to use catalogue as a form; guidebooks provide a means by which to navigate museum collections and offer a concrete interpretation of the items on display.

Victorian museum-goers would also have been familiar with the concept of taxonomy, although it, like catalogue, was not a nineteenth century invention. Taxonomy can be traced back to ancient Greece, entering its familiar form in 1738 when the Linnaean system was developed (Anderson 17, Yoon 26). The Victorian twist on taxonomy was to apply it concepts to social categories such as race, class and sexuality (McClintock 52,46, Ledger and Luckhurst 291). Intended for use as a tool for organizing the natural world, taxonomy became an ordering system for locating one's place on "the evolutionary family Tree of Man," or within the "racial hierarchy," or marking one's proximity to the "dangerous" or criminal classes or those classified by a "sexological taxonomy of perversion" (McClintock 37, 38, 46, Ledger and Luckhurst xxi).

\footnotetext{
${ }^{41}$ For a discussion of the historical use of catalogues, see Strout, Ruth French. "The Development of the Catalog and Cataloguing Codes.” Library Quarterly. 24.6 (October 1956) 254-275. Print.
} 
Like cataloguing, this "social" taxonomy was meant to illuminate and order that which threatened to overwhelm. In the guidebooks, taxonomy could organize the contents of the Exhibition; outside, it addressed concerns of disease, poverty, savagery, and deviant sexuality. These areas may also be seen as places where "a large number of possible orders glitter separately in the dimension, without law," but the Victorians created taxonomies that quickly shut down any "possible orders" that seemed deviant.

Museums contributed to this repurposing of taxonomy. Racial exhibits positioned the white, European male at the top of the evolutionary ladder. Animals were grouped into "families" that bolstered notions of the "natural, patriarchal family," visibly denouncing alternative familial constructions (matriarchal, homosexual, etc.) (McClintock 45). Confronted daily by newspaper accounts that ranked and classified people, visitors to the Great Exhibition would have quickly recognized the taxonomical techniques at work inside the Crystal Palace (where Britain's placement indicated its superiority) and in guidebooks. The taxonomies used were either those officially set out by the exhibition (raw materials, machinery, manufactures, and fine arts, including the thirty-four classes into which these were separated) or spatial taxonomies, which introduced readers to objects as it led them through a visible hierarchy.

The final museual method used by the guidebooks is the simplest. In order to display culturally relevant objects, museums authenticate and evaluate specimens before displaying them. In chapter three, it will be shown that methods of evaluating and authentification migrated outside of the museum to become concerns within the novel and within the world. Inside of the Crystal Palace, visitors might evaluate objects based on the enjoyment or wonder they provided or by their usefulness or perceived wealth. The floor plan arrangement lacked price tags, so these evaluations were likely quite subjective. However, the "material arrangement of the various 
national departments" did "invit[e] the observer to contrast them competitively," an invitation also taken up by the editors of the guidebooks, who weighted their catalogue entries with adjectives denoting the value of the goods on display (Gillooly 28). This value might be cultural, national, industrial, or merely aesthetic and would have influenced reader opinion of the objects just as museum plaques influence visitor interpretation today.

The museual methods outlined above did not merely migrate into guidebooks; they also appear in the newspaper accounts of Henry Mayhew that would become London Labour and the London Poor and in his novel: 1851. Just as the guidebooks and catalogues attempted to combat the disorder and endless possibilities of interpretation arising from the Great Exhibition by containing it and imposing a narrative structure, Mayhew harnesses museual methods in an attempt to order and contain the world of the lower classes. Like the guidebooks outlined above, London Labour relies on catalogue and taxonomy to organize "the misery, the vice, the ignorance, and the want" that attend the world of Victorian poor (447). Mayhew's mission, like that espoused by the nineteenth-century museum, is one of social uplift. In presenting his catalogue of the poor, he hopes to change attitudes about the poor and to "induce" his readers "to apply [themselves] steadfastly to the removal or alleviation of those social evils that appear to create so large a proportion of ... vice and crime" (447).

The format of London Labour closely resembles the catalogue format used by exhibit guidebooks, with a strong reliance on print rather than engravings. Indeed, "the same acquisitive and classifying impulse that fed the Great Exhibition" and the catalogues that described it may be seen operating in the pages of London Labour (Joshi 97). Like the Exhibition and its catalogues, London Labour first outlines the broad categories that will be examined. In place of raw materials, machinery, manufactures, and fine arts, Mayhew introduces the "large and varied 
class" "who obtain their living in the streets of the metropolis" and proceeds to arrange them "under six distinct genera": street-sellers, street-buyers, street-finders, street-performers, artists and showmen, street artizans [sic], and street-labourers [sic] (5). Having established these categories, Mayhew goes on to use headings similar to that in the leather goods example above. These headings are followed by essential information that will allow the reader to recognize and distinguish the class being described. Under the heading of "OF THE SELLERS OF TREES, SHRUBS, FLOWERS (CUT AND IN POTS) ROOTS, SEEDS, AND BRANCHES," one finds the following information: "The better class of flower-girls reside in Lisson-grove, in the streets off Drury-lane, in St Gile's, and in other parts inhabited by the very poor. Some of them live in lodging-houses, the stench and squalor of which are in remarkable contrast to the beauty and fragrance of the flowers they sometimes have to carry thither with them unsold" (60). Mayhew then follows this generalization with the story of two orphan flower girls. As a catalogue entry, their story serves as a representative specimen of a type, just as a particular piece of sculpture might illustrate that entire class in a guidebook.

These catalogue entries are highly detailed, often running to three pages in length. By including specific details (how much is paid for lodging, what times of day the girls work), Mayhew suggests that the entire class of street sellers may be known and understood through these examples, just as the guidebooks suggested that one could know the world of manufacture by studying a few of the key goods on display in the Crystal Palace. Furthermore, just as "things ... spoke for themselves, using... a language of their own" in the Great Exhibition and in its catalogues, Mayhew allows his "specimens" to speak for themselves by transcribing their words, dialect and all, and commenting on their behavior. The little flower girl above is quick to combat notions of her ignorance by claiming that she can read and proving it by reading from The 
Garden of Heaven (Mayhew 63). Her behavior suggests that she is aware of attitudes toward her class and wishes to situate herself in opposition to such expectations. Just as objects seemed to take on characteristics of living things within the Crystal Palace, Mayhew's catalogue entries transform a class regarded as impediments or objects back into human beings with voices.

This transformation is complicated, however, by Mayhew's recourse to taxonomy. Like the guidebook editors, the journalist turns to this museual method to impose order on the world of the London Poor. While human beings do occupy a place in the taxonomic tree, the average person rarely contemplates taxonomy as applied to anything but animals and plants. For the Victorians, taxonomy became a tool that could be taken out of the natural history museum and applied to the world of goods (in the Crystal Palace) or to the world of human beings sharing their streets. Such a taxonomy would lead to knowledge of the London underclass and methods for ameliorating their condition. In order to discipline the poor into proper and productive members of society, a hope held out by London Labour and one of the missions of the nineteenth-century museum, they first must be made known.

In order for his readers to recognize particular members of the London poor, Mayhew creates a detailed taxonomy that perfectly matches the taxonomic order of Kingdom, Phylum, Class, Order, Family, Genus, Species, even though he does not write it out in the Linnaean form. ${ }^{42}$ If we use the family of "street-sellers" as an example Mayhew's taxonomy is as follows: Kingdom: Workers

\footnotetext{
${ }^{42}$ It must be noted that, as a journalist rather than a scientist, Mayhew sometimes misuses taxonomic terminology. The families listed above, for example, are written as "genera" in his text, a classification that makes no sense if we are to take sellers of a specific article as a species, which they must be as they are the stopping point of the taxonomy (5). Furthermore, Mayhew sometimes complicates his taxonomy with mentions of race, distinctions between English and Irish sellers, for example. Such errors suggest that the application of taxonomy outside of the museum was not the perfect science it may have masqueraded as. It did, however, carry scientific authority and thus should be taken seriously.
} 
Phylum: Working Class (other phyla would include the middle class or upper class, for example)

Class: Working Class of London

Order: Street Workers

Family: Sellers (Mayhew also includes the families of: Buyers, Finders, Artists, Artizans, Labourers)

Genus: sellers of fish (also included are: sellers of vegetables, sellers of eatables and drinkables, sellers of stationery, sellers of manufactured articles, sellers of second-hand articles, sellers of live animals, sellers of mineral productions and curiosities) Species: sellers of wet fish (Mayhew 5-8).

By reading and studying the articles that became London Labour, the Victorian middle and upper classes could learn to distinguish individuals on the street down to the hyper-specific species or sub-species level. For example, in the case of street artists, readers could recognize street showmen (genus) and then further distinguish the species "extraordinary persons" and move on to the sub species of "dwarfs," all in a single assessing glance. The streets of London become a museual space where the average person can practice the museum's method as they assess and categorize their fellow citizens. Taxonomic work becomes the work of the masses rather than the work of an individual scientist.

The idea of the museum as a cultural structure or space that can discipline bodies and citizens through such methods as taxonomy is not a new one. Eileen Hooper-Greenville theorizes the "surveyed and controlled" space of "the disciplinary museum" as a central nineteenth century structure that offered democratic education and yielded "docile bodies" $(167,190)$. In these 
spaces, great works of art or specimens, such as specimens of the healthy human body, were "held up as examples to be imitated" the viewing of which was meant to "civilise the mass of people" or at least inspire them into "behaving well" (Hooper-Greenville 189). Bennett follows this work, revealing the nineteenth-century museum as the space where bodies "function as... object $[\mathrm{s}]$ made visible by" science "while also doubling as the subject of the knowledge" science has "[made] available" and where such subjects could be "inscribe[d]" with "self-activating and self-regulating capacities" that would yield sober, productive, and upright individuals $(7,20){ }^{43}$ What is unique in the case of Mayhew is that the museum walls have been replaced with the city skyline. Instead of objects grouped together, the exhibits are bodies in constant flux. In identifying and assessing the London poor, the upper and middle classes become the example to be emulated even as they merely go about their day to day lives. Imposing order via a museum framework has become the day to day work of the average person. In 1851, Mayhew will carry these museual methods even farther to show that it is also the work of the novel reader.

Known for his work as a social researcher and a pioneer in the developing social science of ethnography, Mayhew's name usually arises only in connection with his work London Labour and the London Poor. Conducted throughout the 1840s, Mayhew's interviews with the underclass of London were collected into three volumes and published in 1851 (the same year that the Great Exhibition opened). While Mayhew's chronicles of street sellers and prostitutes have acted as a major source of information for scholars since their publication, the novel 1851 has passed out of print and has garnered little critical attention. ${ }^{44}$ Indeed, the current critical conversation surrounding the novel consists of a handful of articles, including notable works by

\footnotetext{
${ }^{43}$ Other scholars have also forwarded Foucaultian readings of the museum space. See Hetherington, Kevin. "Foucault, the museum, and the diagram." The Sociological Review. 59.3 (2011) 457-475.

${ }^{44}$ Mayhew's London Labor is seen as partial impetus for the growth of social exploration writing in the second half of the nineteenth century. See Ledger, Sally and Roger Luckhurst. "Outcast London." The Fin de Siecle: A Reader in Cultural History c. 1880-1900. Oxford: Oxford University Press, 2000. 25-27. Print.
} 
Philip Landon and Nick Fisher. ${ }^{45}$ If 1851 is considered within a museum context it proves a valuable insight into the power of museum culture and the importance of the Great Exhibition of 1851, an event, along with other world's fairs, that has been credited with "shap[ing] both the form and substance of the modern world" (Rydell 136). Chronicling one family's increasingly desperate attempts to visit the great museum prototype, the Great Exhibition of 1851, the novel replicates the overwhelming effects of the exhibition itself. Using museual language and museual methods found in the catalogues created to aid visitors to the Crystal Palace, Henry Mayhew ultimately makes the palace the last place one would want to visit. He unmakes the museum (and the traditional form of the novel) with the very schemes of classification which have been made to give it order.

As 1851 begins, the world takes on the aspect of a museum, just as it does in the pages of London Labour where individuals become walking examples of a taxonomic order. The text begins with the words "The Great Exhibition." ${ }^{\text {"46 }}$ This is a Genesis-like moment, with Mayhew signaling the importance of exhibition in the hierarchy of the world. At this foundational moment in the text the audience has not even been introduced to the major characters whose adventures they will share. Instead, they learn of the massive impact of the exhibition: "nine-tenths of the human family" are marked out as "sight-seers," individuals who have already absorbed a nineteenth century museual culture founded in catalogue and taxonomy (Mayhew 1). The reader is to join these nine-tenths in a sight-seeing journey through the novel and to the Crystal Palace

\footnotetext{
${ }^{45}$ Landon's reading of the novel marks the Crystal Palace out as a haven of respectability and insists that characters must "conform... to the Crystal Palace ideology" in the face of a "hostile world" (35). Fisher's view is historical, chronicling Mayhew's engagement with the articles housed in the Exhibition (10). Thomas Richards also briefly considers the novel in his work The Commodity Culture of Victorian England. Richards sees 1851 as a "conversion narrative" that transforms Cursty Sandboys into a consumer (37). While I agree that Sandboys is driven from home for lack of commodities, I argue that he is much more closely aligned with the laboring classes (through his knowledge of minerals, for example) than with the "tightfisted middle class" (36).

${ }^{46}$ Later in the text when the event is opened it will be listed as GREAT EXHIBITION OF ALL NATIONS and set apart from the rest of the novel to indicate its importance (128).
} 
itself. Like the upper and middle class readers of London Labour, the reader is to see in order to know and Mayhew quickly begins ordering knowledge in accordance to practices of the nineteenth-century museum.

In the first pages of 1851 , the reader is indoctrinated into the world of catalogue, the most popular museual method used by journalists and guidebook writers in an attempt to organize the wealth of wonders gathered beneath the jewel box lid of the Crystal Palace. As a showing of "All Nations" the Great Exhibition will be attended by: "the Esquimaux [sic]," "The Hottentot Venus," the "Yemassee," "the Truefit of New Zealand," "the Botocudo," "the Maripoosan," "the Cingalese [sic]," and "the King of Dahomey - an ebony Adam" (Mayhew 1-2). This list testifies to the breadth of the British Empire, indicates the universality of the exhibition, and demonstrates the museum's ability to transform a sight-seer into an exhibit. By entering into the space of the exhibition, colonial visitors could quickly become visual attractions like the Hottentot Venus, ogled as British "possessions" by those living in the British Isles. ${ }^{47}$ Mayhew will continue to highlight the contrast between native British visitors and foreigners throughout 1851, but his primary purpose in documenting those who will attend the Exhibition is to make the reader work through layers of lists. The list above is one of his shorter efforts and his recourse to cataloguing does not yet seem subversive.

At first glance, the lists featured in the first few pages of 1851 may simply seem amusing to the reader, a minor intrusion into the larger story of the Sandboys. However, the amount of cataloguing that Mayhew subjects his audience to quickly becomes exhausting. Take, for example, London's preparations, its emphasis on itself as a properly cosmopolitan city (fitting

\footnotetext{
${ }^{47}$ The Crystal Palace and the other exhibitions it gave rise to functioned as "human showcases" in which "objects were seen to be less interesting than human beings and, through the medium of display, human beings were transformed into objects" (Greenhalgh 82). Below, this will be shown to be the case for laborers, who were romanticized by the rhetoric of the Exhibition but feared and ogled in the flesh.
} 
site of a museual event like the exhibition). ${ }^{48}$ The reader is told about a hotel of all nations offering a mere seventeen amenities (all listed) and a restaurant serving delicacies suited to foreign visitors - seven examples are given (Mayhew 2). The narrative of the Sandboys will never intersect with this hotel or this restaurant. The reader is ejected from the space of the narrative by the sheer work of reading through lists. The same process could occur within the pages of the guidebooks or catalogues. Take, for example, this excerpt from A General Guide to the British Museum from 1893:

"In order to render this skeleton [of a sperm whale] more instructive, and to bring it into relation with the elementary specimens of osteology in the adjoining bay (No. 1., west side), the names of the principal parts have been attached to them. This will enable the anatomist to trace at a glance the extraordinary modifications in the form and relations of its component bones which the huge skull has undergone, and will show in the clearest manner to the least instructed visitor the so-called fin or flipper of the whale is composed of all the same parts - shoulder, elbow, wrist, and fingers - as his own arm and hand" (Flower 26).

The narrative being conveyed is about evolution and the similarities between human development and the development of "one of the most colossal of animals," but it is not the same type of narrative one would expect to find in The Moonstone or Middlemarch (Flower 26). Of course, such novels have been criticized for just the type of writing one would expect to find in a museum guide. Critics of the Victorian novel often light upon its cataloguing tendencies, its overly detailed fictional spaces and imagined worlds cluttered with lists of goods, items, and

\footnotetext{
${ }^{48}$ Buttermere will remain the anti-museum, an area that is not urban, lacks modernity, and does not struggle with urban problems the Sandboys clan will encounter throughout the text.
} 
things (Freedgood 1, 19-20). Such lists, while used by their creators as a bid for realism, earn criticism precisely because they break the narrative. Mayhew capitalizes on this effect and amuses himself with 1851 - an attempt to convey a narrative almost completely through catalogue.

The catalogues of 1851 proliferate as the reader draws closer to the opening day of the Exhibition. Surnames of Brits preparing for invasion appear in the novel in alliterative lines ("Beds, Bucks, Notts, Wilts, Hants, Hunts, and Herts,") that are both tiresome and generic (Mayhew 2). The world itself is reduced to a series of relationships presented in catalogue form: "not a village, a hamlet, a borough, a township, or a wick," or "such was the state of the world, the continent, the provinces, and the metropolis" (Mayhew 3). Writing after the Exhibition had commenced, Mayhew was well aware of its ability to dumbfound visitors, and he recreates that effect for the reader by bombarding her or him with endless lists.

While Mayhew's work is largely comic, one suspects that he had some sympathy for the readers he set to laboring. Mayhew, writing for the Edinburgh News and Literary Chronicle attempted a serialized catalogue of the contents of the Crystal Palace. But despite the many lists that appear in both 1851 and London Labour, "this project utterly defeated him" and was never completed (Fisher 10). ${ }^{49}$ Though students of the Crystal Palace may regret this unfinished project, Mayhew's attempts at taxonomy were not all slated for failure. Focusing on people rather than objects, the author uses just such a taxonomy to detail the London underworld, repeating the classifying and disciplining methods used in London Labour. As Cursty and his family journey toward London, they begin to participate in the very activity that awaits them at the Crystal Palace: they gawk. In the train carriage that carries them to London, the Sandboys are

\footnotetext{
${ }^{49}$ For the importance of catalogue in London Labour see Nancy Metz "Mayhew's Book of Lists" Studies in Literature 14.2 (1982) 42-50. Print.
} 
examined by a "strange gentleman" even as "the Sandboys, one and all, did the same for the strange gentleman" (44). The characters are then endorsed in this action: "and truly the gentleman was so very strange, that the curiosity of his fellow passengers was not to be wondered at" (Mayhew 44). In this small moment, Mayhew reminds readers of the importance of vision and visual assessment in the nineteenth century. Strange sights were meant to be taken in, wondered at, and assigned a place, whether inside of the museum or out. The museum world of London Labour reappears, enlarged, in 1851 and the Sandboys prove unfortunately naïve as to its methods. For an audience schooled in museual techniques, this naiveté becomes a source of amusement; the audience can laugh at the Sandboys because they can never imagine being in their shoes.

Indeed, the museum's effect on the world is so large that almost no one encountered by the Sandboys lacks the ability to assess, authenticate, and taxonomically place all that they see. Though likely no museumgoer, the strange gentleman being observed on the train has had more practice with visual assessment than the Sandboys clan and he pegs them before they can assign him to some undesirable category. Having done so, he offers them a lesson in the taxonomic table of London's underclass. He begins with broad groups (genus) of thieves (family), which he classifies by both their formal name and a description of their actions. These broad groups make up another of Mayhew's lists that the reader must labor through:

"cracksmen, or housebreakers; rampsmen, or footpads; bludgers and stick-clingers, or those who go out plundering with women; star-glazers, or those who cut out shopwindows; snoozers, or those who sleep at railway hotels; buzzers, or those who pick gentlemen's pockets; and wires, or those who do the same kind office for ladies. . . thimble-screwers, or those who wrench watches from their chains; dragsmen, or those 
who rob carts and coaches; sneaksmen, or those who creep into shops and down areas; bouncers, or those who plunder by swaggering; pitchers, or those who do so by passing one thing off as another; drummers, or those who do the same by stupefying others with drink; macers, or those who write begging letters; and lurkers, or those who follow the profession of begging" (Mayhew 43).

Not only does this section of text change from narrative to catalogue, it provides a detailed taxonomy of London thieves and suggests that the city might not be just a showcase for items and goods, but a living, moving museum space full of unsavory specimens. ${ }^{50}$ That their railway companion is so well versed in this taxonomy should make the Sandboys wary, especially when this taxonomic table is further broken and down and detailed over the following three pages. There is a Linnaean skill here that could only be gained by close study of the subjects being discussed. When he fails to make use of this taxonomy to read their guide as a thief, Cursty exhibits a failure to fit within 1851's museum world.

The museum enters 1851 through catalogue, but Mayhew is not content to disrupt the narrative merely by importing methods from the museum. At the same time that the text is being transformed into a string of lists, the world of 1851 is being made into a museum, rife with all of the problems that plagued visitors of the Crystal Palace. In the museum world that Mayhew creates, individual subjects can be exhibited like objects, objects take precedence over people, authenticity is of paramount concern, and the one edifice that can hold out salvation is the

\footnotetext{
${ }^{50}$ Within the novel, the use of catalogue is not restricted to the metropolis, the urban environment of the museum where it would have proven a native form of reading. In that rural idyll of Buttermere, Mayhew again resorts to list after list to establish the scene in the mind of the reader. "Social facts" such as births and deaths are delivered in precise numbers, linking 1851 to London Labor (Mayhew 6, 7). Further catalogues tally all of the things which cannot be found in Buttermere (bills, tradesmen, attorneys, tax-gatherers, butchers, bakers, drapers, booksellers etc.) the births, deaths, and inhabitants of the village ("the Flemings, the Nelsons, the Cowmans, the Clarks, the Riggs, the Lancasters, the Branthwaites, the Lightfoots...) the comments of a local visitor's book, the contents of Cursty's son Jobby's pockets, and, finally, the exodus of the people of Buttermere for London and the Exhibition (Mayhew $4,6,5,10,14,15-17)$.
} 
museum itself. Only the museum can organize, order, and discipline the chaos faced by the Sandboys clan. By making these themes an integral part of the text, Mayhew uses his text as a commentary on the world (re)created in the wake of the Exhibition. ${ }^{51}$

As shown in London Labour, the city streets have become museual spaces where their occupants practice observation and assessment. Entering this space, Cursty also enters a taxonomic hierarchy in which his clothing and manners rank him above the many specimens of the London poor. On a search for lost items and money, Curtsy and his son Jobby find themselves in the museual space of a secondhand market (Mayhew 98-99). This place is a horrid parody of the museum (a second example of which will be seen in the dust heaps of Our Mutual Friend in chapter three) where instead of exotic diamonds and industrial treasures, people bargain over "bones and bits of old iron and pieces of rag" (Mayhew 99). Here, "refuse [is] piled on the ground like treasure" - and is still worth more to the inhabitants of this world than any museum could ever be (Mayhew 99). Inside such a world, Sandboys becomes "the universal object of observation," considered so avidly precisely because he does not belong (Mayhew 101). Landon sees the "dangerous, unsanitary Old Clothes Exchange" as a dark and twisted inversion of the Great Exhibition where Cursty is an object of interest rather than the sightseer he would be inside of the museum itself (32-33).

The bargaining and squabbling over goods that occurs in the marketplace is not a classbased phenomenon. Rather, in Mayhew's museum world, objects have the ability to become

\footnotetext{
${ }^{51}$ Another aspect of a world in the wake of the Great Exhibition was commodity culture. Thomas Richards highlights the connections between the Exhibition and commodity culture, pointing to the Crystal Palace as a sort of meta-factory that helped to produce the conditions and products that ushered in the modern relationship between people and goods. Richards marks the Exhibition as the moment at which the commodity began to become "the centerpiece of everyday life, the focal point of all representation, the dead center of the modern world" (1). What he refers to as "The Great Exhibition of Things" ushered in capitalism as "a dominant form of exchange" with "a dominant form of representation": the piles of glittering goods arranged within the Crystal Palace (Richards 3). Mayhew was not ignorant of the effects of the Crystal Palace on the world of buying and selling. Indeed, he documented a fear among the working class that the true purpose of the Exhibition was for the bourgeoisie to learn how to craft cheaper goods and lower the wages of those who worked for them (Fisher 10).
} 
more important than the individuals who possess them. Nor is this merely a manifestation of Mayhew's imagination. According to the work of John Plotz, some Victorians regarded their possessions not merely as goods or mementoes, but as material manifestations of elements of their selfhood. This attitude can be seen in 1851 in the character of Mrs. Sandboys. In her mind, possessions stand in for the respectability of her family. It is for this reason that she is initially moved to leave Buttermere despite her dread of London's squalor. Having survived several deprivations, she cannot bear to see Cursty without proper pants or Jobby without shoes. The loss of these items is equated with a loss of self and of standing so devastating that even London may be risked.

Plotz describes a connection similar to that of Mrs. Sandboys in his reading of The Mill on the Floss. For Mrs. Tulliver in Mill, "[a]ny object monogrammed with her initials or her family name seems an almost physically attached extension of herself' (Plotz 8). When Mrs. Tulliver discovers that her sense of selfhood is "physically enshrined in objects that can, as fiscal currents [or, in the case of the Sandboys, sheer misfortune] fly away," she experiences "despair" (Plotz 8). This type of despair is exactly mimicked in 1851. Mayhew writes that "the peculiar feature of Mrs. Sandboys' mind was to magnify the mildest trifles into violent catastrophes. If a China shepherdess or porcelain Prince Albert were broken, "she took it almost as much to heart as if a baby had been killed" (Mayhew 13). Thus, when Mrs. Sandboys prepares to journey to London, she must have twenty-three pieces of luggage containing her "gowns," "morning dresses," "evening dresses," "cardinals and paletots," "night-caps and night-gowns" "muffs and tippets," "whiskers and artificial flowers and feathers," and "bustles and false fronts" (Mayhew 34). These function not only as female ornamentation, (or as another catalogue) but as objects that contain sentiment and selfhood and which act as a bulwark against the filth and chaos of the 
fearful city. The loss of such items leaves Mrs. Sandboys literally and figuratively exposed to the terrors of London, as illustrated in the catalogue of thieves above.

Besides acting as embodiments of self, goods also helped people to make sense of their neighbors in an urban environment. The same sort of visual acts used in the museum can migrate outside of it to help city dwellers determine the class and status of those around them. With class and status came respectability and trust. Naturally, such an environment bred concerns about imitation and counterfeiting - concerns about authenticity. Such concerns are brought home to the Sandboys clan when Mrs. Sandboys trades away an old pair of Cursty's trowsers [sic]. These pants contain articles that can be used for identification, articles which can confirm the carrier's authenticity. Their purchaser, a flower seller, soon drinks himself into trouble with the law and is arrested as Curtsy Sandboys. In the eyes of middle class Victorians, this thief and drunkard is the type of person who could have been helped by the museum, but in a world obsessed with the Exhibition, he focuses only on drink and popular entertainments all the while acting under a counterfeited identity (Mayhew 106-107). The existence of such individuals highlights the usefulness of the taxonomy created by Mayhew in London Labour.

Unable to read such taxonomies themselves, the Sandboys continually run afoul of London's lowest classes. Mrs. Sandboys is as easily "counterfeited" as her husband, her alter ego being arrested shortly after his (Mayhew 111). In an urban world, museual reading is necessary to parse the true from the fake. The Sandboys clan lacks the skill to perform these readings and lacks the documents (the marriage license, etc.) to prove their own validity. In Buttermere, they would have been vouched for by kin, community, and reputation, but the Great Exhibition is about appearances and the Sandboys' rustic behavior fails to garner them respect (Mayhew 112). The canny friend of the flower seller, arrested as Mrs. Sandboys, makes deft use of museual 
claims, proving her authenticity when she produces the stolen marriage license. The judge even agrees that no policeman should not have insulted her without proof. ${ }^{52}$ The next day, the papers print Cursty's assault on the police, making it a proven fact. Because there is a real, tangible paper out in the world that says that Cursty is a thief, he will be read as one thereafter with no chance to clear his name. When he finally does reach the Crystal Palace, he is denied entry because of his crimes and his inability to prove that he is not the man who has committed them.

The solution to all of the problems in the novel is ever present, shimmering the distance. Every deficiency attributed to the Sandboys can be corrected by the museum. Having entered the halls of the Crystal Palace, they will, Mayhew suggests, become more cosmopolitan, become more aware and educated regarding their fellow citizens, and become better and more tasteful consumers. All of these benefits are suggested early in the text when Cursty announces his intention to abstain from visiting or allowing his family to visit the Great Exhibition. Surprised by his attitude, Cursty's well-meaning neighbors first set out to woo him with tales of "amusements and gaieties at the capital" (Mayhew 15). When Cursty fails to yield to such persuasions, the denizens of Buttermere shift to familiar museum rhetoric, emphasizing the museum's educational value and citing travel as a way of "expanding the mind" (Mayhew 15)..$^{53}$

\footnotetext{
${ }^{52}$ The real Mrs. Sandboys is far better at the museual skill of judging true from false (authentic from fake) than her husband. When Cursty is taken in by a thief on the trains, Mrs. Sandboys doubts his tales and claims.

${ }^{53}$ When Cursty raises objections citing the dangers of London, another surprising aspect of the museum enters the text. According to Tony Bennett, Victorian museums are key cultural institutions in which to study Foucaultian paradigms of surveillance. This analysis has also been taken up by scholars of Victorian optics; Crary sees the museum as providing a single "correct" viewpoint that it pushed all visitors toward. Cursty's fears about the busy metropolis and its rate of crime are soothed in a catalogue of Foucaultian language. Cursty learns that "all the dormitories [are] to be well lighted with gas," and "watched over by efficient wardens and police constables," two methods used by the museum in South Kensington to police its lower class audience (16). Furthermore, "an office [is] to be opened for the security of luggage" and "every care [shall] be taken to ensure the comfort, convenience, and strict discipline of so large a body" (16-17). In highlighting strict discipline, Mayhew is drawing attention to one of the museum's primary concerns. Middle class citizens never quite got over the fear that lower class visitors to the museum would behave badly (even criminally) despite the institution's civilizing influence. In a sense, they were to be proved right. Lower class audiences often had no qualms about seeing the museum by day and returning to the
} 
As a form of rational recreation, the museum held out the promise of guiltless entertainment precisely because it "contain[ed] some element of useful instruction or moral uplift" (Barber 16). The entire village of Buttermere is able to leave en masse for London because the Exhibition holds out the promise of learning as well as that of enjoyment. Enjoyment is not enough to motivate the head of the Sandboys clan, however, and it is only when Cursty's family endures an impressive catalogue of deprivations (hunger, inability to replace household goods, lack of coal, etc.) that they join the world in flocking to the center of "stuff" - the Great Exhibition. By making this a viable solution (and, indeed, the mechanism by which the novel's plot is moved forward) Mayhew argues that it is only a museual environment that can rescue the middle class from squalor, disease, and depredation..$^{54}$

The nineteenth-century museum's freighted existence as an object of salvation and discipline to be used to "transform the inner lives of the population so as to alter their forms of life and behaviour" did not mean that it was free from anxieties about the very classes Mayhew sought to catalogue in London Labour (Bennett 20). The museum might have been an institution for helping the lower classes, but there were concerns regarding their behavior in such a space. Mayhew and others like him also expressed concern about how much actual and practical good the museum could actually do. These concerns enter 1851 when Mayhew leads readers to "one quarter of the deserted town where people were not holiday-making, but still labouring - for what was to them indeed - dear life" (Mayhew 56). In this place it is quite clear that the, "workmen [have] no money to spend on pleasure" but their absence from the Exhibition still

gambling house or pub by night; the two forms of entertainment did not cancel one another out. Since the danger and crime of London will ultimately prove too much for Cursty and his family even during the greatest museual event of the nineteenth century, the museum's power to discipline is severely undercut in the novel.

\footnotetext{
${ }^{54}$ Mayhew's work in London Labour allows us to extend this thesis. It is not only the middle class who can be rescued by the museum, but all classes.
} 
proves a shock to the wondering Cursty, who questions them about their absence. His query is greeted by bitter laughter and disdain for an exhibition that causes a working man's earnings to fall from "three and ninepence" to "two and a penny" (Mayhew 56). "Exhibition of Industry!" one of the workers cries, "let them as wants to see the use of industry in this country come and see this here exhibition" (Mayhew 56). While the world admires the fairyland of glassy walls created by Joseph Paxton in Hyde Park, the Great Exhibition remains just that - fantasy - to those who must continue to earn their bread, those for whom even shilling days are far too costly. This scene also plays out in London Labour where street sellers lament that "the Great Exhibition can't be anything for me" despite its celebration of labor (Mayhew Labour 74). Others hope that the crowds brought into the city will bring more work (or more charity) their way and "speculat[e] whether the Great Exhibition will be 'any good' to them or not" (Mayhew Labour 95). The celebration of labor passes these laborers by, suggesting that the transformations promised by the Crystal Palace may not reach into every life and that those who most need the benefits promised by the museum may be those least likely to reap them. ${ }^{55}$

Mayhew's worries about the reach of the palace give way, in 1851, to broader, public concerns about working class behavior within the Exhibition. Prior to the shilling day, "the great topic of conversation" is how the working class will behave in a museum environment. As noted in the first chapter, the behavior of the working class was often a concern for those who promoted museums as transformative for workers. ${ }^{56}$ The crowds streaming for London raised worries about "unprecedented crime, disease, and anarchy" and were "fueled by the Chartist rallies and Continental upheavals of 1848 , and by escalating problems of urban health" (Landon

\footnotetext{
${ }^{55}$ Reformers like Henry Cole would confront these problems, prompting traveling exhibits taken out of the palace and reassembled in factory towns (Black 33).

${ }^{56}$ See "The Public in the Museum." The Emergence of the Modern Museum. Jonah Siegel, ed. Oxford: Oxford University Press, 2008 Print. Pg 79-136.
} 
28). Such worries often centered on the working class. In 1851, questions about working class behavior include: "Would they come sober? will they destroy things? will they want to cut their initials or scratch their names on the panes of the glass lighthouses?" (Mayhew 161). Barbara Black echoes these concerns when she documents middle class fears about the working class vandalizing statues or being given ideas by classical nudes (104). By asking these questions, the narrative reproduces a cataloguing and taxonomic process - labeling the working class as problematic, setting them off from the middle and higher classes - even as it argues that the museum might save them. These working class individuals represent the same problem as the mountains of articles piled inside of the Crystal Palace. Like them, they hint at the possibility of lawlessness, of any of a dozen outcomes - Foucault's heteroclite made flesh and represented by bodies that have previously been marked out as sites of disease, disruption, crime, and madness.

The answer to this fear was the same answer Victorians gave in the face of the Exhibition's overwhelming abundance: discipline. Victorian fears about the working class were met a particularly Foucaultian manner. The police force is "strengthened" and visits are "engineered"; entry fees are kept at rates that bar working class entry except for special shilling days (Landon 28). In the case of the working classes, nothing was left to chance. Travel, lodging, and even spectatorship were "regulated" through "pre-planned itineraries" and "order and hygiene" were emphasized and attended to in detail (Landon 28). Mayhew replicates these arrangements in 1851 , creating a catalogue of disciplinary measures. The reader learns that in preparation for the arrival of the lower classes, barriers have been erected, policemen are stationed, an "extra force" is arrayed around the jewels of the Queen of Spain, and ushers are placed inside to help guide the expected crowds of tens of thousands (153). Other nineteenth century methods for disciplining museum visitors included "crowd reports," "police guards," 
"guidebooks that instructed museum goers on proper behavior," "casings, cordons, special lighting, and labels" - all instituted to insure the routine nature of the museum experience and the proper behavior of the bodies (of all classes) that sought it (Black 104).

Victorian visions of the museum's power to inaugurate change in the working class fell short. (Indeed, the Victorian faith in progress embodied under the Palace's great glass panes would ultimately be destroyed in a world where more bullets could be manufactured than men to kill with them, in a world of mud and trenches and barbed wire and rapid-fire artillery). Individuals were, of course, sustained and inspired by the museum and scholars like Lara Kriegel have shown that laborers were able to capitalize on the museum's popularity and use the Crystal Palace as a platform from which to demand more rights (160-190). Ultimately, the museum and its methods of taxonomy and catalogue could help to explain the poor and to provide examples by which they could improve their lives, but it could not discipline them into upright middle class citizens unless it offered practical improvements in areas such as housing, sanitation, and nutrition. This failure is not the reason that scholars of literature should turn to the museum as a nineteenth century structure that influenced texts and day to day life alike. Despite its failings, the Crystal Palace's importance and, by extension, the museum's, lies in its ability to inspire such lofty dreams for an entire age. Today, it may be easy to cast stones at that glass house and to see it as a container for Victorian failings like colonialism, consumerism, and nationalism, but the Great Exhibition was also a grand experiment in optimism and a material example of the Victorian faith in progress. When considering Victorian literature and Victorian life these principles should not be forgotten. ${ }^{57}$

\footnotetext{
${ }^{57}$ It is worth noting that as of 2014, plans have been approved for the rebuilding of the Crystal Palace on its original site and in its original glory.
} 


\section{Chapter Three: "In that Bony Light": The Museum Economy of Our Mutual Friend}

"You can't buy flesh and bone in this country, sir; not alive, you can't."-Mr. Wegg, Our

\section{Mutual Friend}

In one of the early chapters of Charles Dickens's Our Mutual Friend, Mr. Venus

relays Pleasant Riderhood's damaging pronouncement: she does not "wish... to regard

[herself], nor yet [wish] to be regarded, in that bony light" (84).$^{58} \mathrm{~A}$ comic moment in the text, Pleasant's rejection of Venus-as-taxidermist/taxonomist establishes a subplot of thwarted romance and creates another connection through which the large cast of characters can be linked to one another. This scene in Venus's shop and its "general panoramic view" of specimens, relics, and bones also introduces a concept that is central to the reading of Our Mutual Friend: the museum (Dickens 81).

In ways that can be observed in but which also far exceed Dickens's novel, the natural history museum ${ }^{59}$ shaped nineteenth-century discourse and ways of seeing. ${ }^{60}$ In the first decades of the nineteenth century, the popularization of natural science led to a collecting boom among all classes. ${ }^{61}$ By the middle of the century, most materials associated with collecting specimens had become relatively affordable. Increased industrialization made such

\footnotetext{
${ }^{58}$ All further references are to the 2009 Oxford edition and are cited parenthetically by page number.

${ }^{59}$ Art museums also had considerable impact on Victorian culture, and contributed to nineteenth-century viewing practices. However, through its focus on value-through-death Our Mutual Friend is more thoroughly engaged with museums of natural history.

${ }^{60}$ Jonathan Crary's seminal study, Techniques of the Observer, notes that not only were new ways of seeing prevalent in the nineteenth century; the Victorian era "produced a new kind of observer" (3). The argument made here intersects with Crary's work in seeing the museum as one of the technologies which assisted in the "modernization" of the observer, making him or her "adequate to a constellation of new events, forces, and institutions that are together loosely... definable as "modernity" (9). In presenting narrative models dependent on seeing exhibits in a certain way, museums schooled observers in proper viewing techniques even as outward signs of control (police, cordons, etc) began to disappear. Within the museum, Crary's vision is of an observer whose subjectivity is privileged at the same time that he or she is subjected to greater controls (15-18)
} 
implements available to even the working classes (Black 22, Merrill 10-12). The 1850s also saw private collections mirrored in the national and systematic collecting cases of the museum which showcased native and imperial treasures, contributed to cultural health, and represented England's global prominence and growing affluence. All of this was done while drawing hundreds of thousands of visitors every year. ${ }^{62}$

These visitors engaged in a new type of seeing and a new type of reading: a museual literacy. Though most museums provided catalogues or pamphlets, the written descriptions they contained were secondary to the visual messages relayed by the exhibits themselves. Indeed, middle class Victorians believed that the type of literacy learned within the museum contributed to public education. ${ }^{63}$ The privileged position of a museual vocabulary in Victorian novels like Our Mutual Friend is partly explained by the connection between a museual literacy, which reads for value, and the work done by readers of the novel. ${ }^{64}$ This latter type of reading also engages valuing practices and relies on a reader's ability to distinguish truth from falsehood and worthwhile textual clues from stylistic markers. ${ }^{65}$

Even in classes where literacy might be low, museums worked to educate the public in viewing practices shared by museums and novels alike. ${ }^{66}$ Offering to provide a rapid education through sight, museums in working class neighborhoods "competed directly with

\footnotetext{
62 Sharon MacDonald notes that museums and their collections "allowed nation-states to show their mastery over the world - something that colonial powers were especially able to demonstrate through the accumulation of material culture from the countries that they colonized" ("Collecting Practices 85). Britain was able to reinforce its identity as a growing imperial power by exhibiting foreign cultures at home.

${ }^{63}$ See Aileen Fyfe, "Reading Natural History at the British Museum and the Pictatorial Museum" pp198 and Barbara J. Black On Exhibit: The Victorians and their Museums pp 32-35.

${ }^{64}$ Similar vocabulary and emphasis on visual interpretation (the act of learning-through-sight) also marks nineteenth-century works like: The Old Curiosity Shop (1840), Henry Mayhew's London Labour and the London Poor (1840), Gabriel Dante Rossetti's “The Burden of Nineveh" (1856), George Gissing's The Nether World (1889), Oscar Wilde's The Picture of Dorian Gray (1890). Imperial exhibits also flourished at the beginning of the twentieth century, and continued to influence novels like Rudyard Kipling's Kim (1900) and Henry James's Wings of a Dove (1902).

${ }^{65}$ For a richer explanation of the connections between the rise of fiction and the art of reading for value in the economic sphere, see Mary Poovey, Genres of the Credit Economy 57-85.
} 
the public house" by remaining open longer and offering exhibits that would appeal to their specific audience (Black 33). ${ }^{67}$ Middle class beliefs suggested that these working class museum visitors might go on to turn their leisure hours to making their own collections, providing "healthful outdoor exercise" and a "constructive and thoughtful" alternative to such lower class vices as drinking or gambling (Merrill 37). A museual gaze became part of life in Victorian England for millions of individuals from all classes. ${ }^{68}$

Despite the middle class vision of the museum as providing a form of cultural salvation to the lower classes, those exhibit-filled halls were never entirely free of Victorian anxieties. While proponents of museum-guided public education welcomed the opening of museums to wider audiences, the composition of those audiences raised concerns about noise, hygiene, and danger to the exhibits themselves. In response, museums married the civilizing effects of the exhibits to an intense supervision, meant to discourage theft, lewd behavior, and the defacement of the works on display. ${ }^{69}$ Additional problems arose when addressing discrepancies between the viewers' level of education and the presentation of the exhibits; curators could no longer assume that all viewers would interpret the exhibits in the same way, as new museum audiences lacked the cultural and educational background that would have helped them to contextualize the exhibits (Fyfe 197-198).

\footnotetext{
${ }^{67}$ Tony Bennett's "Speaking to the Eyes: Museums, Legibility, and the Social Order" provides a clear picture of the nature of the visual scripts used by museums to educate working class viewers. See also: The Politics of Display: Museums, Science, Culture edited by Sharon Macdonald, London: Routledge, 1998. (25-35).

${ }^{68}$ The venues of visual education were varied, ranging from the museum to the menagerie to the industrial exhibit, and even including spectacles such as the Punch and Judy show and the freak show.

${ }^{69}$ For a discussion of how this supervision has been theorized, see Mason's discussion of "The "Foucault Effect" in "Cultural Theory and Museum Studies" pp 23-24 and Barbara J. Black The Victorians and Their Museums pp 26, 35.
} 
Modern concerns over authenticity, identity, and value (economic and otherwise)

centered on the urban site of the museum. ${ }^{70}$ It is no coincidence that these very concerns are

mapped out in a novel so concerned with museums: Our Mutual Friend. One need only think

of the Lammles scheming over the oblivious Georgiana, treated, by her father, like a piece of

plate (143). Central to the cityscapes of which they were a part, Victorian museums conferred

value, assured the viewer of authenticity, and manufactured national narratives that worked to

"fight the alienation and isolation that characterized modern urban existence" through the

formation of a unified audience: the public (Black 25-26). Surrounded by strangers and

lacking the reference points of neighbors and family connections, city-dwellers were faced

with the problem of reading the surrounding populace and sorting "authentic" identities from

those that might misrepresent themselves. ${ }^{71}$ Deciding whom it was safe to buy from, associate

with, even marry, became a preoccupation of Victorian urban life. ${ }^{72}$ The economic concerns

of the museum: evaluation/classification, authentification, acquisition, and contextualization

echoed the day-to-day concerns of the Victorian urbanite, and were enacted whenever

\footnotetext{
${ }^{70}$ I use Anthony Gidden's sense of the modern which encompasses industrialization, capitalism, and surveillance as established in post-feudal Europe (14-15).

${ }^{71}$ Dickens illustrates this fear in one of his early descriptions of Mr. Wegg, who "range[s] with that very numerous class of imposters" who deceive themselves regarding their true nature just as much as they deceive others (53).

${ }^{72}$ This is a central theme of Our Mutual Friend, which is illustrated through the counterfeiting couple, the Lammles. A longer study might also consider counterfeits, ever a threat to the museum, focusing on the Veneerings and the Lammles. The Veneering family acquires all the markings of old wealth: house, furniture, servants, plate, carriage but everything is brand new. Dickens even offers the suspicion that "if they had set up a great-grandfather," (the phrase "set up" harkens to taxidermy) "he would have come home in matting ... without a scratch upon him" (6). "High varnish and polish" are used to cover over the newness of the Veneerings and dazzle old money into coming into their circle (6). The Veneerings in all their polished newness are the very people who give the stamp of authenticity to Alfred and Sophronia Lammle. All that anyone needs to know about the Lammles is that they are people of property and Alfred, though he has "never... achieved success in anything, never originated anything, never produced anything," is authenticated as a man of property, a man of a certain class, and a man worth marrying. Watching their wedding ceremony, Mrs. Tippins does not speculate on their future happiness, but, rather, calculates the cost of the wedding: the bride's dress is "thirty shillings a yard" and her veil "fifteen pounds," the bridesmaids' dresses are "twelve and sixpence a yard" (119). Often studied for its commentary on wealth, the obsession with money in this novel has not been properly connected to museum culture. The same methods used in the museum to evaluate objects of art or natural history specimens are applied, in the cases of the Lammles, to evaluating a mate. The ultimate question is how much is he or she worth and the ultimate irony is that both of the Lammles are con artists, trusting in the authenticity of the other. Alfred defends himself by saying, "I asked Veneering and he told me that you were rich" (123). A word from the Veneerings is enough.
} 
strangers met. Using a museual lens, this chapter enters the museum's urban environment and engages with characters from every level of class in order to demonstrate the interconnectedness of the novel and the museum culture in which it flourished. Such a reading recuperates characters previously read as insignificant (or late additions like Mr. Venus) and demonstrates their value and significance within both the novel and a culture attuned to the language and values of the museum.

\section{Part One: The Influence of the Museum}

\section{1: Collectors}

Though the primary place that this chapter will intersect with the museum is that of the museum economy, evidence of the museum's influence appears early and often throughout the text. Personalities associated with the museum are prevalent, including collectors, observers, and human exhibits. The following sub-sections will examine these characters, focusing on Gaffer Hexam, Silas Wegg, the Boffins, Bella, Eugene Wrayburn, Mr. Riah, and Jenny Wren.

It is to Paris rather than London that Dickens attributes a monomaniac tendency to collect through the eerie image of "wonderful human ants that creep out of holes and pick up every scrap" of litter or refuse, but the museual activity of collection also occurs in the pages of Our Mutual Friend and the forms it takes are equally unsettling (144). At the opening of the novel, the reader finds Gaffer and Lizzie Hexam engaged on the river, their gazes no less "intent and searching" than those of a group of archeologists employed to uncover museumworthy treasures. Dickens assures the reader that the master of the boat cannot be a fisherman, a waterman, a lighterman, or a river-carrier, but connects Gaffer Hexam to "dread" and "horror" as well as "the slime and ooze" that makes up the bottom of the river (1). As the scene 
continues, Hexam is firmly established in the museum economy described above, working to collect (and fleece) bodies in exchange for reward money that is then turned into "meat and drink" for his children (3). This grisly economy (in which Hexam is characterized as a vulture) might seem quite distant from the clean and open displays of the nineteenth-century museum (4). However, the nineteenth century natural history museum was implicated in activities no less unsettling, including grave-robbing, racial anthropology, plunder, and trophy hunting (Mackenzie 4). Hexam's collection of bodies mirrors the bodies on display in the museual space and connects Our Mutual Friend to the violent collecting processes that were so much a part of nineteenth-century museum making. ${ }^{73}$ It is no accident that this violence finally entangles Hexam, making him an object in the river to be collected and towed ashore. ${ }^{74}$

Mr. Boffin, though considerably less grim a figure than the "half-savage" Hexam, also engages in acts of collection and hoarding that call the museum to mind (1). Made newly affluent by Harmon's death, Mr. Boffin sets out to amend his neglected education with a collection of "wollumes [sic] Red and gold. Purple ribbon in every wollume..." and the collection of "a literary man," Silas Wegg $(52,49)$. The latter collectible proves also to be a curiosity, with Boffin exclaiming, "A literary man - with a wooden leg - and all Print is open to him!" (49). Clearly astounded (and quite mistaken) that the world of literature might be given over to such an oddly made creature as Wegg and withheld from him despite all of his money, Boffin eagerly engages his service, snapping up Wegg as if "at a sale," just as he acquired his "wollumes" (52). Boffin also goes on to collect "one exceptional kind of book": texts associated with misers (466). Like the early natural history museums of the nineteenth

\footnotetext{
${ }^{73}$ While it is possible to argue that Hexam does not actually keep the bodies he collects, his assortment of handbills, which he proudly displays to Mortimer Lightwood and Eugene Wrayburn, represent this collection and bring it into his home.

${ }^{74}$ Hexam, unlike the objects he collects or the specimens stripped of life in the museum, is given a last moment of dignity by the inspector who notes, "I still call it him, you see" (175).
} 
century, Boffin is less interested in a representative specimen than in amassing a great collection. The contents of the collection need not even be exceptional; for Boffin, "size, price, [and] quality were of no account" and his appetite for more miserly tomes remains "as avaricious" throughout the novel as it had been "at the first onset" (467). Like Boffin, the nineteenth-century museum (and its modern counterpart) has been criticized for hoarding much more than it can ever make use of or display (Boffin's miserly texts remain quite hidden after their purchase). As sometimes happens in the world of the museum, the act of collection becomes its own motive.

Another character who works through an intense series of evaluations before rejecting the role of collector is John Harmon. Harmon's evaluation of Bella Wilfer takes place precisely because he wishes to know if she is worth collecting, and, indeed, if it is worth assuming his former identity (and the wealth attached to it) in order to collect her. In the course of trying to determine whether Bella has been corrupted be wealth, he suggests that she visit her home. She argues with him over his insinuations that she cares little for her former life or her family, but still shows that she can apologize when she has wronged another, an act that he says "shows [her] to such an admirable advantage" (309). He uses the argument itself to force Bella to exhibit herself as either a spoiled creature ruined by money (Dickens's "mercenary little wretch") or a good-hearted woman who might care for a man for his own sake, even if he did not possess great wealth (319).

\section{2: Observers}

With the rise of a museum (centered) culture, the pivotal player in the hierarchy of the human senses, the eyes, became increasingly important. Underlying the seemingly inherent 
value of exhibits, collections, and specimens was a "deep faith in the power of unfettered sight" (Bellon 301). The need for visual proof dominated the world of natural science and influenced the construction of museum exhibits (Merrill 117). ${ }^{75}$ As Jonathan Crary has noted, importance was given to one's personal vision in the nineteenth century. Museum spaces attempted to create a platform from which to see one dominant message, but visitors, especially colonial ones, challenged this. ${ }^{76}$ Acts of intense observation further marks Our Mutual Friend as a text influenced by the practices of the museum.

Detached observation, the observation of the flâneur, enters the text through the character of Eugene Wrayburn. ${ }^{77}$ Eugene embodies the spirit of the flâneur: he walks in order to "see and be seen" and his walks are a "crowd practice" performed before an audience, specifically Bradley Headstone (Shields 65). Walter Benjamin notes that, to the flâneur, "the fruits of idleness are more precious than the fruits of labor" (453). Concerned only with escaping his father's designs for his life, Eugene drifts around the city, "float[ing] with the stream through the summer" sometimes engaging in work, but usually idling away his time (144). The flâneur makes panorama (a museual device) of the city and they have been imagined

\footnotetext{
${ }^{75}$ Indeed, the most famous of the Victorian scientists, Charles Darwin, established his credentials through staring through a microscope at a miniscule, parasitic, Chilean barnacle. The "illformed [sic] little monster" would yield great returns in helping to support Darwin's evolutionary theories, and Darwin's writings about his observations would help to maintain the pivotal role of visual education in nineteenth-century science (qtd. in Desmond and Moore 369).

${ }^{76}$ See Joseph Childers' "Peering Back: Colonials and Exhibitions." Victorian Prism. Ed. James Buzard, et al. Charlottesville: University of Virginia Press, 2007. 203-215. Print.

${ }^{77}$ The flâneur can also be connected to Crary's study of vision, his insistence that the nineteenth century produced an observer whose individuality was of more importance even while he or she was brought under additional control. George Simmel writes, "The deepest problems of modern life derive from the claim of the individual to preserve the autonomy and individuality of his existence in the face of overwhelming social forces, of historical heritage, of external culture, and of the technique of life. ... In addition to more liberty, the nineteenth century demanded the functional specialization of man and his work; this specialization makes one individual incomparable to another, and each of them indispensable to the highest possible extent. However, this specialization makes each man the more directly dependent upon the supplementary activities of all others. ... An inquiry into the inner meaning of specifically modern life and its products, into the soul of the cultural body, so to speak, must seek to solve the equation which structures like the metropolis set up between the individual and the super-individual contents of life" (11). The flâneur is the figure who navigates the metropolis in an attempt to regain some amount of the individuality that Crary and Simmel discuss.
} 
as characters with "the social privilege of a bachelor with a moderate independent income";

Eugene is just such a character (Brand 33). Defined by his need to keep moving, he continues seeking out new entertainments, describing himself with the words "I, so soon bored, so constantly, so fatally," (147).

Eugene becomes a crucial character when his gaze falls on Lizzie, when he "turn[s] his eyes upon the building where, as he had been told, the lonely girl with the dark hair sat by the fire" (163). As he comes closer to watch, she is transformed into an exhibition - framed by the windows, illuminated, and held behind panes of glass, "a sad and solitary spectacle, as shown him by the rising and falling of the fire" (163). ${ }^{78}$ Watching, he sees the Gaffer's collection of handbills, "the drowned people starting out and receding by turns" (164). At this horrible exhibition he "glance[s] slightly" but he "look[s] long and steadily at her" (164). As the text continues, Eugene resists the idea that Lizzie might be exhibited to anyone else. When his friend Mortimer Lightwood says that he'll take a look at the girl, Eugene counsels him against it, saying, "Best not to make a show of her" (166).

Eugene then makes a spectacle of himself by tormenting Bradley Headstone. He reports to his best friend, “... Mortimer, I goad the schoolmaster to madness... I do it thus: I stroll out after dark, stroll a little way, look in at a window and furtively look out for the schoolmaster" (542). By strolling and window gazing, Eugene becomes a flâneur, his performance calculated to make Headstone "under[go] grinding torments" (543). Caught up in "the pleasure of the chase," Eugene makes certain that he is being watched and "tempts" Headstone all over the city $(543,542)$. The connection between observation and the museum was well-established in the

\footnotetext{
${ }^{78}$ For the importance of glass in Victorian viewing culture, see Andrew H. Miller. Novels Behind Glass. Pp 1-14 Cambridge: Cambridge University Press, 2008. Print.
} 
nineteenth century. Our Mutual Friend's intense emphasis on observation marks it as a museual text. ${ }^{79}$

\subsection{Exhibition}

No reader familiar with Dickens's work can remain unaccustomed to his tendencies to exhibit characters that seem taken from a nineteenth-century freak show. However, even the most ordinary Dickensian creation can be made into a museum piece, exhibited for both the reader and the other characters within the novel. The Boffins are remade into an exhibit for Bella in order that John might evaluate them. Once the scheme has been revealed, they even celebrate the skill with which they performed their appropriate parts, with Mr. Boffin managing to sound more like a menagerie than a museum with his, "Mew, Quack-quack, Bow-wow!" (778). Initially, the Boffins exhibit Bella in order that she is able to make a good marriage. For Bella, "the question is not for a man, but for an establishment" (469). As a captivating and bewitching beauty, she hopes to "captivate" money (321). The Boffins seek to provide her with joy in the midst of her sorrows and extend to her the pleasures that their wealth will provide them. As their "acquisition" she proves "far too pretty to be unattractive anywhere, and far too quick of perception to be below the tone of her new career" (307). In fact, Bella is able to correct the Boffins and help them "act up" to their fortune. Bella's "appearance and manner" are improved through wealth so that she can better display herself (307).

\footnotetext{
79 Other observers include Wegg, who is singled out by Dickens as one who " "took a powerful sight of notice,"” notice largely confined to the museum house and its fictional inhabitants and Miss Peecher, ever on alert for Bradley Headstone, whom Dickens confounds with an object by making her envy his watch guard $(46,219)$. Miss Peecher even uses Mary Anne as a lookout (232). Peecher, unlike Harmon, looks not in order to evaluate but in hope of possessing.
} 
Bella's continual display by the Boffins indicates her status as a collectible. It also introduces another museual concept: the notion of the connoisseur. Bella's desire for "an establishment" is telling. She considers herself too valuable to be purchased (and maintained) by all but a handful of very wealthy men, an attitude supported by Mr. Boffin (in disguise as Boffin-the-miser), who describes her as a treasure who has not been "made to be snapped up by fellows that had no money to lay out; nothing to buy with" (590). This version of Bella is one (like Mr. Venus's exhibits) on which many resources has been expended, and she is expected to recoup their value through a profitable alliance. ${ }^{80}$ In this museum economy, she is exhibited because she is valuable and can only be collected by someone with the proper resources.

Also exhibited in Our Mutual Friend are the orphans, Jenny Wren, Mr. Riah, and Silas Wegg. Wegg is the most literal of the exhibits and the character most easily connected to the natural history museum. Indeed, the reader meets the entire Wegg only in Venus's shop, where his leg bone is part of Venus's collection of "warious" bones. Asking whether or not his bone has been incorporated (articulated) into a full model, Venus agrees that while Wegg is "not worth much even by his own account for "miscellaneous working in," he "might turn out valuable yet as a Monstrosity" (82). While this is primarily an opportunity for Dickens to comment on Wegg's character and foreshadow his later villainous actions, it is a museum culture that provides him the means to do so, a culture that would be interested in viewing monstrosities, a culture capable of seeing things in that bony light.

Dickens's orphan exhibition is largely a satirical one and the Boffins' hunt for an orphan to care for quickly stirs up fears of "orphan swarms" "obstruct[ing]" the "neighborhood

\footnotetext{
${ }^{80}$ This is a version that Dickens has allowed the reader to see before. Bella's rejection of the view of herself as "property" is tangled up in the idea of being viewed that way by someone as poor as "Pa's Lodger" (308).
} 
thoroughfares" (102). While a connection could be made between these imagined swarms and the fear of the crowd that haunted the museum, they are more interesting when taken as an exhibit of bodies (as many museum exhibits were) that act as a contrast to the healthy middle class body. Furthermore, these bodies are every bit as much objects as those found in the museum. Described as "in stock" by the curate Mr. Milvey, the orphans are transformed into acquisitions that might be obtained through "a transaction in the way of barter" (105). The chosen orphan becomes a specimen, interchangeable with any other specimen of its type. The orphan is to be the new John Harmon - "one [the Boffins] are going to give the name to" (111). He will be a living memorial and suggests that John Harmon may be represented by a suitable specimen as easily as Mr. Venus might represent a cat with the proper bones. Certain qualities are to be desired but the identity remains interchangeable. Indeed, the Boffins take on a museual trust when they vow to keep the house they have inherited "in remembrance of [their] old master, [their] master's children and [their] old service" they will "keep [the house] as it stands" (185). Furthermore, they see themselves as custodians of the Harmon name, vowing to literally see that the inscriptions written by the Harmon children will not be erased, but also to live up to the names and keep the remembrance of the "poor little children" (184).

The final two exhibits can be considered together as they are taken by Miss Abbey who "doubts whether she had not dreamed these two rare figures into the bar" (440). Experimenting with opening and closing her eyes to test the reality of Mr. Riah and Jenny Wren, Miss Abbey finds them real and worthy of observation (440). There is much in the text to suggest that the reader is to do the same. Indeed, Jenny, through her name, is associated with the natural history museum, where the specimen of a wren would not have been uncommon. Furthermore, she is like Wegg in being something of a monstrosity with her repeated lament of a bad back and 
queer legs (222). Jenny even describes herself as "lop-sided" (433). This would be enough to make her a worthy exhibit, but she also possesses hair worthy of Rapunzel - "a golden stream" that "flow[s] down to the ground" and makes a "golden bower" about her body (439). Furthermore, Jenny is difficult to classify. On seeing her, Miss Abbey questions Riah, trying to determine whether Jenny is a child or a grown woman (440). Initially she is introduced with just such taxonomic uncertainty, called "a child - a dwarf - a girl - a something" (222).

Jenny is also connected to a central part of the museum economy mentioned above death. It is she who chooses to make the house-top of Fledgeby's business into a faux garden spot, complete with "a few boxes of humble flowers," a carpet, books, and fruit (279). The chosen spot, derided by Fledgeby, permits a view of "the clouds rushing on above the narrow streets, not minding them, and [they] see the golden arrows pointing at the mountains in the sky from which the wind comes." High above the world, Jenny claims that "you feel that you are dead" (281). The rooftop heaven allows for tranquility, thankfulness, peace, and a pity for the living, "crying, and working, and calling to one another down in the close dark streets" (281). The way that death is valued by Jenny (and, by extension, Lizzie) emphasizes the museum economy.

Finally, Jenny makes exhibits of others. ${ }^{81}$ Upper class ladies are observed by Jenny as patterns for the dolls she makes and dresses. She relates, “...I dare say they think I am wondering and admiring with all my eyes and heart, but they little think they're only working for my dolls!" (436). Jenny even uses the clergyman from her father's graveside service as a model for the doll that will "unit[e] two of my young friends [the dolls] in matrimony" (734). Finally, Dickens makes her father an exhibit of what drunkenness may do, just as nineteenth

\footnotetext{
${ }^{81}$ For a discussion of Jenny as a creator see Garrett Stewart's "The Golden Bower of Our Mutual Friend." ELH. 40.1. 1973. 105-130. Print.
} 
century natural history museums exhibited healthy specimens beside unhealthy ones in order to persuade their visitors to pursue a healthy life (733). Jenny even predicts a museual fate for him, “... fit for nothing but to be preserved in the liquor that destroys him, and put in a great glass bottle as a sight for other swipey children of his own pattern" (533).

Like Jenny, Riah is exhibited to the reader, but Fledgeby (Fascination Fledgeby sounding much like the name of someone who would run a spectacular entertainment) also exhibits him, using him to force his clients into paying over money without ever revealing that he is involved. Jewish stereotypes serve to frighten his clientele into payment. Introducing Riah, Dickens places him in an exhibit of the counting house, among "light boxes," "strings of mock beads," "samples of cheap clocks," and "samples of cheap vases of flowers," "Foreign toys all," (276). As Asma notes, specimens only take on meaning within the context of the exhibit - the objects surrounding them give them meaning (36). Riah takes on meaning through his association with money and "foreign toys." Dickens also contrasts him with Fledgeby. Riah "[stands] with his bare head bowed, and his eyes (which he only raise[s] when speaking) on the ground" (276). His clothing is described as "worn" and "shabby" but he lacks the meanness and avarice that attend Fledgeby (276). The exhibit Fledgeby has arranged is so effective that even when Riah explains that he does not own the business he laments, "They never believe me" (277). However, Riah redeems himself when he realizes that he is being used very much as a museum specimen might, made to stand in for his entire race. "In bending my neck," he laments, "I bent the unwilling necks of the whole Jewish people" (726). As a Jew, Riah exists as a specimen under Christian eyes and his actions can never merely "[compromise] no one but [his] individual self"; instead, his actions always "compromise the Jews of all conditions and 
all countries (726). Just as the nineteenth-century museum taught viewers to observe a single specimen as representative of an entire group, Dickens uses Riah to stand in for his entire race.

\section{Part Two: The Museum Economy in Our Mutual Friend}

The museual moments examined above form a series of miniature displays around the primary exhibit at the heart of the novel: the museum economy that envelops Bella Wilfer and John Harmon. This economy is established by a character that seems to have no connection to the pair, but who embodies the connections between the museum and the economy: Mr. Venus. Pondering his doubled income (half from his stall, half from his new occupation as Boffin's reader), Silas Wegg makes his way "towards the poorer shops of small retail traders," and toward Venus (77). The shop's “dark, greasy entry" connects the grease of the Industrial Revolution to Venus's "lovely specimen[s]," $(78,81)$. Furthermore, the smell of the shop calls up the image of the exhibit on display: "musty, leathery, feathery, cellary, gluey, [and] gummy..." (78). These smells are associated with the tools of the taxidermist: "gum cement, gum paste, flour paste, a solution of gum arabic" along with "corrosive sublimates, solution of pearl ashes, and arsenical compositions" (Cotsell 107). ${ }^{82}$ These same tools were central to the natural history exhibits found in Victorian museums. At one point in the text, Venus is even shown articulating some specimens for a museum (500). Finally, Venus sells one of his specimens, a stuffed canary, directly connecting the profits of his work with the "animation" found in the dead bird "making up his mind to hop!" (81). The spectacle of the canary, however small, is valuable for its beauty and its ability to appear lifelike.

The declaration that began this discussion takes place in this scene and enforces the connections between the economy and the museum. Pleasant's desire not to be seen in "that

\footnotetext{
${ }^{82}$ For a discussion of the centrality of taxidermy to Victorian natural science, see Asma pp 22-25.
} 
bony light" is a refusal to be placed into a museum economy in which her value becomes associated (through Venus's profession) with death. The idea of value from death is central to the museum enterprise, which "uses and then discards nature (the animal's body) in the service of culture" (Black 37). Museums preserve present culture by building on the bones of the past; the culture of the other is cleared away so that the supremacy of the (collecting/viewing) self can be assured. The violent connotations in the Greek origins of the word "authentic" testify to this. "Authenteo" means both "to have full power over" and "to commit a murder" (Trilling 131). Death is ever a part of the vocabulary of the museum enterprise ${ }^{83}$, a connection Our Mutual Friend makes explicit through its characters. ${ }^{84}$ As shown above, Mr. Venus's wealth is linked to his ability to create the suggestion of life in the bodies of dead animals. The Hexam family draws bodies from the river and turns them over (with lighter pockets) to the police in order to collect the reward money. The Boffins ascend to their possession through Harmon's death (and bring Bella along). Riderhood attempts to trade on his knowledge of Harmon's death in order to collect a reward. Most importantly, John Harmon enacts and suffers his own death in order to evaluate his prospective bride. In a novel "obsessed with death," Harmon is not merely able to make use of the museum economy; he is also incorporated into it (Levine 152). His dead body, displayed to the Boffins, confers wealth on them because he is no longer able to inherit. Mr. Boffin calls the connection that allows him and his wife to inherit "mysterious," but Dickens makes it clear that the idea of display is central to their ability to

\footnotetext{
${ }^{83}$ The link between value and life (and death) has been explored by Catherine Gallagher in The Body Economic. Her study of Our Mutual Friend takes place in the context of her concept of "bioeconomics" or "the political economy's concentration on the interconnections between populations, the food supply, modes of production and exchange, and their impact on life forms generally" (3). In her study of Dickens, Gallagher emphasizes the prevalence and influence of natural science in the nineteenth century and demonstrates its connections with the economy. However, in the (at times) "ghoulish network of economic circulation" she traces through the novel, she fails to account for the paradigm of the museum, and its influence on the text (94).

${ }^{84}$ The most explicit example in the text is Riderhood's resurrection, wherein "the spark of life within him becomes separable" from the rogue to whom it belongs (443). Riderhood is made valuable only when he exists in a state close to death.
} 
collect wealth (92). Harmon's body must be pulled from the river, displayed, and identified in order for wealth to be transferred from him to the Boffins. ${ }^{85}$

In death, John gains a museual ability to evaluate and assign worth. As a live heir, he could not expect to observe his prospective bride outside of the context of their economically motivated match, so any evaluation would be tainted. He acknowledges this in an early evaluation of Bella, noting her "so insolent, so trivial, so capricious, so mercenary, so careless, so hard to touch, so hard to turn," - "And yet so pretty!" (208). In his new identity Harmon is able to observe the woman who would have been his wife in order to determine whether she is worth collecting, worth coming back to life to collect. In order to evaluate the authentic Bella, rather than the woman/object willed to him, Harmon enters her context by making himself a lodger at her home. ${ }^{86}$ His initial observations of her are markedly covert; when presented with his would-be wife, he rests his eyes on her "for an instant" before looking away (38).When she signs his contract as a renter, his look is "stealthy," taking in her "beautiful brown hair" and "coquettish face" (39). His still and silent watching separate him from the transaction taking place and isolate him from the other characters in the room; they also mark how he will function in the text, as one who watches and assigns value.

Even before Bella is exhibited to John Harmon, she is displayed for the reader in her mourning clothes as "a kind of widow" who had been left to Harmon "in a will, like a dozen

\footnotetext{
${ }^{85}$ The necessity of display does not end with Harmon's body. The former Harmon residence is to stand untouched, both museum and mausoleum in tribute and remembrance. The structure of the Bower seems as though it could be one of Mr. Venus's exhibits, showing "staircases, balustrades, and rails" that appear "denuded to the bone" (183). The Boffins also recognize the necessity of "keeping the names" of the two Harmon children who have died (184). ${ }^{86}$ Harmon is not the only watcher in then chapter that bears his name. Once he departs the scene, the female Wilfers offer their readings of him. To their eyes, Rokesmith looks like a thief and murderer, which he is. Having killed himself (John Harmon) and stolen/crafted an identity, Harmon might qualify for their bad opinions. What is more interesting is Bella's declaration that she has never seen such an "exhibition" (40). She is able to use the cultural language of the museum to assess Rokesmith.
} 
of spoons" $(38,37) \cdot{ }^{87}$ In this section of the text, Bella becomes an object to be given as inheritance, which shows her value. Dickens pauses on her "exceedingly pretty figure and face," marking her as a character to be looked at (34). The reader is given a woman on display who has a presumed value, but who has been cut off from her "glimpse of wealth" and restored to a context of "insolvent circumstances" for which she believes herself unsuited (36, 32). This presentation of Bella is museual; she is meant to be read and evaluated by the reader as well as by Harmon. Evaluation, both aesthetic and economic, is a central part of the museum experience, and Harmon observes Bella with an eye to collecting.

Bella's time as an exhibit within her native context is destined to be short. Feeling that Bella has both natural value through her beauty and that Harmon's choice of her for his son confers value upon her, the Boffins ask her to live with them. Deciding that "it's no good...being kept here like a Wax-Work" and that they must "act up" to their fortune, the Boffins take on Bella, who is "much to pretty to keep shut up" $(99,109) .{ }^{88}$ The adoption of Bella suggests that her beauty is too valuable to be kept out of sight. Interestingly, Mrs. Wilfer, on receiving the Boffins, declares Bella to be "accessible" and "much sought after": museual connotations $(108,110)$. Her description of Bella could easily be applied to an exhibit. Furthermore, the "pleasant creature" is enticed precisely because the Boffins provide her with a proper context in which to exhibit herself, the "nice house" with its "nice carriage," (109). The residence itself conjures the Crystal Palace with its "halls of dazzling light" (181). These museual connotations are emphasized when it is revealed that Bella's sole purpose

\footnotetext{
${ }^{87}$ Harmon's father chose Bella for her promise, linking her to the idea of the collectible, which assumes value over time (Dickens 42). Despite the fact that one text is American and the other British, Bella's promise may profitably compared to Mary McAleer Balkun's analysis of Lily Bart; see "Connoisseurs and Counterfeits: Edith Wharton's The House of Mirth" in The American Counterfeit pp 72-96.

${ }^{88}$ This mention of the waxwork connects the Boffin wealth with both death (the original waxworks were death masks of executed nobles) and with spectacle
} 
within the new Boffin residence is to "enjoy and attract" (205). She is museum visitor and exhibit in one, ensuring the pleasure of those who look on her while enjoying being observed. Harmon follows her to this new residence in order to continue scrutinizing and evaluating her. His actions are firmly entrenched within a museum economy.

\section{Part Three: Articulating Museual Narratives}

The negative economic visions of Our Mutual Friend have come in for considerable critical attention. The analysis above has supported this criticism in showing the negative features of the museum economy, with death underscoring value and commodification triumphing over love. However, Dickens does not see the museum-as-concept as primarily negative. This can be seen in his own preoccupation with visual experience and his use of visual learning in his novels, from Punch and Judy shows to wax works exhibits. ${ }^{89}$ In Our Mutual Friend, Venus offers an alternative way that the museum paradigm could be used, and it is a redemptive one. However, Venus (and Dickens) is more complex than that. For all that he redeems by revealing Wegg's treachery, Venus also represents the ability of the museum to objectify, even destroy, the other.

Mr. Venus comes in for little critical attention, but it is he that illuminates the proper use of the museum, and, indeed, the true value of the museum to society. ${ }^{90}$ Museum studies have long recognized the centrality and importance of narrative. ${ }^{91}$ Narrative functions in collecting processes through the notion that "objects are meaningful and that collecting and organizing them can be a means of making sense and gaining knowledge of the world"

\footnotetext{
${ }^{89}$ See The Uncommercial Traveler (1860) pp 45-46, 120-122 in which Dickens visits the morgue and associates it, through waxworks, to the museum and Michael Slater's Charles Dickens: A Life Defined by Writing pp 32, 71.

${ }^{90}$ This may be because of the character's late addition to the text and his assessment as one of Dickens' comic characters. See Cotsell pp 107.

${ }^{91}$ See Black (38-39), Macdonald (A Companion to Museum Studies 26-27, 308, 502), and Zimmerman (27-35).
} 
(Macdonald 85). Through display choices and the groupings of items, collections, and exhibits, museums produce narratives of the cultures they display, and allow their viewers to construct narratives of themselves and their culture. In Our Mutual Friend, Mr. Venus creates a narrative for his life, makes a name for himself, improves his knowledge, and gains in wealth through his shop, which is even explicitly referred to as a museum $(83,780)$.

In the novel, narrative is dispensed from Mr. Venus's shop, produced in a way which mirrors the museum's creation of narratives. Venus creates wholes from parts. In mid-century Britain, many of the sciences were concerned with just this work, including geology and archaeology, which relied on "fragmented remains" to create a narrative of mankind that "replaced the Bible's compelling narrative of time's very clear beginning and no less certain end" (Zimmerman 2, 1). Venus demonstrates his craft in a specimen that he describes to Wegg as having "One leg Belgian, one leg English, and the pickings of eight other people in it" (80). From bits of bones, Venus is able to assemble complete skeletons that offer anatomical narratives to schools of art, museums, and students of science. Venus's creations embody a narrative of progress as seen by the nineteenth century; the state's ability to display museological knowledge shows a certain level of cultural advancement and achievement. Dickens points to Venus's narrative abilities when he writes the scene in which Wegg reads off Venus's title: Preserver of Animals and Birds (a museual skill) and Articulator of Human Bones. Venus's title of "articulator" makes him capable of both "sort[ing]... wertebræ [sic]" and voicing a particular story - a narrative (82).

Venus's narrative possibilities can be traced back to the differences between the forms of collecting which he engages in and those practiced by other characters in the novel. He is not the miser, merely hoarding, and he is not the scavenger, collecting and discarding, 
participating in what Gallagher calls "a ghoulish economy.” Instead, Venus's collections "contribute to [his] sense of identity and function as a source of self-definition;" he is just what his card labels him to be, and his specimens, sold into the world, point additional business back to him so that he has "as much to do as [he] can possibly do" (Muensterberger 4, Dickens 83). ${ }^{92}$ Wegg recognizes his skills, noting his "patient habits and delicate manipulation," "his skill in piecing little things together," "his knowledge of various tissues and textures" and his ability to read and note "small indications" of "great concealments" (303). Venus demonstrates the proper use of the museum economy: creation, admiration, and a sustaining of self-identity. The gain comes from the enjoyment of the creative act, as well as the sale of the creation.

From Venus's ability to assemble a skeleton (or a narrative) comes the ability to read the flesh and character that lines the bones. Of all the characters at work in a museual type of evaluation, Venus makes the most accurate readings; his evaluation of Wegg leads him to class the man as valuable "not for miscellaneous working in. . ." but "as a Monstrosity" (82). To Venus's trained (but comically weak) eyes, Wegg's warped outer shape is a sign by which his inner workings can be found out. Even his evaluations of Pleasant - "worthy of being love by a Potentate!" - are not occluded by a desire to possess or display (83). Interestingly, Venus's readings are just as much a part of the museum economy as those done by Harmon (his skills in taxonomy, anatomy, and taxidermy underlie his readings), but he reads without imposing his character into the narrative because he has not "killed" off his self-identity in order to offer evaluations; instead his identity is linked to the skills that allow him to read bodies.

\footnotetext{
${ }^{22}$ Venus's function is mirrored in the character of Jenny Wren, who builds dolls from scraps. Her creations also make her who she is, and she is willing to sell them rather than hoard them.
} 
Even though Venus's seeing is connected to a wider museum culture, his narrative stands in direct contrast to the other museual narratives being constructed in the city, such as the hoarded mounds. Though grateful for the "bone, feather, and what not," the mounds have brought to his shop door, Venus shows no signs of wishing to hoard anything (84). (One suspects he would even let go of the familiar dueling frogs if the right buyer happened along, and paid with coins unmixed with teeth). He collects from the pleasure of making order, and in order to demonstrate his growing skill at his craft.

The third party in a meeting between Wegg and Mr. Boffin, Venus reads the supposed miser in order to determine the truth of his narrative. ${ }^{93}$ At this meeting, Boffin displays a new haul of miserly narratives to be explored, including Kirby's Wonderful Museum. While Wegg reads Mr. Boffin's actions and determines that he has become a miser, and that his after-hours digging, lit with a dark lantern, is to carry away lost treasures, Venus merely notes that Boffin has only been accustomed to think of one mound as his own. The other two belonged to the “deceased” younger Harmon and Venus doubts Boffin's ability to fashion a narrative of himself on those particular remains. He also resists Wegg's desire to do harm to Boffin in order to gain what he carries away; he resists the underlying museum economy that generates value from death. ${ }^{94}$

\footnotetext{
${ }^{93}$ Venus is especially illuminating in the light of Boffin's miserly narratives. Mr. Boffin purchases literal narratives of misers, regardless of "size, price, [or] quality" (467). He even enlists Bella (in her role as exhibit) to help him find these valuable stories. He instructs Bella to watch the shop windows for "a Life of a Miser or any book of that sort" and he watches her face to see what she has found (467). As a valuable possession, Bella becomes the indicator of value, pointing to and authenticating the types of narratives Mr. Boffin has built up around her.

${ }^{94}$ Interestingly, Venus uses this economy to threaten Wegg, noting. “... I don't just now want any more trophies of my art. But I like my art, and I know how to exercise my art" (496). With his skills, Venus could easily disassemble Wegg and make him into just another trophy.
} 
Venus combats this economy by creating a museual space that acts as a restorative force in the urban environment, an antidote to its deceit and counterfeiting (both social and monetary).$^{95}$ It is no coincidence that Venus's shop is the only space in the book referred to as "Home Sweet Home" (499). The museum, a national space, likewise acts as a dispenser of homegrown, home-affirming narratives. The museum reflected "a productive and reproductive social body" and affirmed the health of the culture of those entering its doors (Black 43). Venus also offers an alternative to the overwhelming scraps of modernity - that "mysterious paper currency" which "hangs on every bush, flutters on every tree, is caught flying by the electric wires, haunts every enclosure, drink at every pump, cowers at every grating, shudders on every plot of grass, and seeks rest in vain..." (144). This evidence of modernity, these scraps of life, this mound-making refuse, towers at the center of Our Mutual Friend, threatening to overwhelm life in a modern world. In the face of these fragments, Venus's weak eyes and wise fingers become heroic, showing the reader that meaning can be fashioned from the refuse and that stories - even animation! - can be drawn from the piles of ash and loss. Venus's articulation is a redemptive answer to those that might be buried by hoarding - that sinister underside of the museum enterprise.

Venus can also be connected to the sinister elements. Throughout the book, Venus uses his skills to make threats. When a boy attempts to cheat him at a sale, he exclaims, "You've no idea how small you'd come out, if I had the articulating of you" (81). Such a threat bears connotations of flesh being removed, life being extinguished. His threats against Wegg are enough to make Wegg "shy" "of the slightest anatomical reference" and he avoids mentioning the word "bone" entirely (576). This, too, is what the museum does. The museum

\footnotetext{
${ }^{95}$ Boffin's counterfeiting of himself emphasizes these dangers in the wider culture.
} 
also causes problems for Venus. "Surrounded by the lovely trophies of [his] art" he finds himself "ruined" by the grisly associations they bear for Pleasant Riderhood.

Though Venus is the primary figure associated with the positive narrative of a life rebuilt from fragments, John Harmon must reconcile his life through the rejection of a particular museual narrative: that of the connoisseur. This rejection begins when John (as Rokesmith) determines to bury his former self forever and to not "return to life" in order that Bella may continue improving. She has become valuable to him not only for her beauty, but for her newfound ability of renunciation. Seeing her choose to leave the Boffin residence where she is exhibited explicitly so that she will attract money, he praises her for being "generous" and "disinterested" - strange words for a lover $(607,606)$. What Harmon is really praising is Bella's ability to reject the narrative of herself as an expensive object being exhibited in order to draw more wealth. Now that she has removed herself from this economy, he is worthy of loving her, and she is worthy of being loved.

Bella answers John's affection with her own. Dickens writes her as seeking a "rosy path" that leads "homeward" instead of an "establishment" in which she might be exhibited to general admiration (671). ${ }^{96}$ Others still perceive Bella in her old light, however. Mrs. Wilfer remarks that she has only been sent home because her "novelty" has worn off, that she is no longer worth exhibiting (612). Returning to the family, Bella actually returns to a linear, familial narrative and disproves Lavvy's observations that she might "detach [herself] from [the family] altogether" (614). This is echoed, too, in the acceptance of John and the "partnership of three" that is made of R.W., Bella, and John. Dickens highlights this narrative, the family context and the family "set" with Bella's pregnancy.

\footnotetext{
${ }^{96}$ Note that the only other reference to home in the text is to Venus's shop!
} 
The domestic narrative, so familiar to Victorian fiction, is not a departure from the museum, nor an example of Dickens turning away from the paradigm that has ruled the text thus far. If Our Mutual Friend ended with the marriage of Bella and John, the museual metaphor would fail to hold such an important place in the study of the work, but the family space quickly comes to mimic the museum space - but one more closely aligned with Venus's store and his narratives of wholes from parts. In fact, with the birth of Bella and John's child, the narrative of the family enters the museum space and the whole is made out of the parts (separate members) and continues into the next generation. Domestic collecting and housemuseums were an integral part of the museum culture that flourished at mid-century, and Dickens does not hesitate to invite the museum home. ${ }^{97}$

The merger of the museum and the domestic is most clearly displayed in Bella, who quickly becomes "a most precious and sweet commodity" in John's life (683). The move to London returns Bella to her former exhibitionary space; John calls the move "undoubtedly a gain" (766). The difference comes in the manner of display. ${ }^{98}$ Refusing to be "distracted for life" by "turn[ing] jealous of every one who used to find my wife beautiful and winning," John comes to admire his wife as an extension of his life rather than as the pretty, pretty object that originally caught his eye and prompted his evaluation (745).

The Boffin mansion attests to this change in looking as well, becoming "a house and home" instead of an establishment (768). It is a home into which Bella has "proved" to fit, having been tested and evaluated and having forcefully rejected the miserly narrative of hoarding represented by Mr. Boffin and the mercenary narrative she once set out for herself

\footnotetext{
${ }^{97}$ See Black pp. 67-77.

${ }^{98}$ The nature of the space is emphasized by the primary exhibit occupying Bella's toilette table, "an ivory casket" containing "jewels the like of which she had never dreamed of" (778). Bella is to be a precious object among other objects, but her exhibition is now connected to the domestic.
} 
(772). Instead she is "a happy piece of work," exhibited anew in the domestic sphere (773). ${ }^{99}$

This "family building" becomes the space for the final exhibit of Bella. Dickens notes that "there was nothing to see but Bella in a musing state of happiness, seated in a little low chair upon the hearth, with her child in her fair young arms, and her soft eyelashes shading her eyes from the fire (778). This "pretty and a promising picter [sic]" shows the museum brought home - an exhibit of domestic bliss to be rejoiced in and treasured (778).

Dickens does not withhold domestic bliss from our original arranger of bones and proprietor of the museual shop. Nor is Mr. Venus forced to completely separate his domestic happiness from his work and the meaning it gives to his life. Pleasant merely requests that he limit his art to the articulation of "men, children, and the lower animals" (782). Pleasant's refusal to be "regarded in a bony light" through the conclusion of the narrative is Dickens's last laugh at the vastness of the museum culture and economy. None of the mid-century Victorians may have been able to escape such regard, and their ways of looking should be considered when we return, as readers, to their world..$^{100}$

\footnotetext{
${ }^{99}$ The primary example of domestic collecting is the Sloane House Museum, which opened its doors in 1836. For a description of this domestic museual space, see Black 67-73.

${ }^{100}$ Nor will museual readings (or, merely keeping the museum in mind) change only the ways in which we view the works of Dickens. Though the Dickens catalogue is rich with museual examples, such as the extensive display of Nell in The Old Curiosity Shop, itself a type of museum, the value of museual analysis is not limited to a single author. Some of the most notable texts ripe for this type of reading include George Eliot's Middlemarch, with its continued return to the idea of Dorothea as an exhibit among the Roman ruins; Wilde's The Picture of Dorian Gray, which invokes the art museum and showcases an obsession with collection; and Henry Mayhew's London Labour and the London Poor, which uses the idea of the exhibit to call for social justice. Barbara J. Black, Aileen Fyfe, and others have shown that a great deal of insight can be gained about Victorian novels by considering the surrounding scientific culture, including museums. In using museum theory to improve our own skills in speculation and articulation, we come closer to seeing the world and literature of Victorian Britain as those who lived there saw it, through a museual gaze.
} 
Enjoyed as the premier piece of nineteenth century sensation fiction, Wilkie Collins's The Woman in White is notable for its barely believable twists and turns, its larger than life characterizations, and its multi-genre epistolary style. ${ }^{101}$ The Woman in White enjoys a rich critical heritage that engages these concerns, as well as issues of gender, psychology, narration, and detection. This chapter seeks to broaden that conversation by investigating an element that merely glimmers at the edge of Collins' text: the museum. ${ }^{102}$ Readers will, of course, be quick to point out that none of the crucial scenes of the novel take place inside of a museum. None of its characters are curators and its central action does not revolve around either an excavation of an Ichthyosaurus or a daring art heist. ${ }^{103}$ Yet, like his friend and sometime publisher Charles Dickens, Collins is capable of channeling the cultural capital of the museum even within a text that might not traditionally be associated with it. In the pages of The Woman in White, the museum's influence appears in the perceptions of individuals as objects, in the museum-related rituals of collection and authentification, and in the museum's Foucaultian penchant toward discipline. ${ }^{104}$ Finally, The Woman in White will be discussed in relation to the culture of natural history as explored in earlier chapters. While these categories of subject/object conflation, discipline, and collection/possession suggest the broad ways that the museum may be

\footnotetext{
${ }^{101}$ See Irvin 228-230 for a discussion of the "image-texts" inserted within the novel.

102 The current critical conversation surrounding The Woman in White is vast. Exemplary explorations of the novel include those by T.S. Eliot (1932), Stephen Bernstein (1993), Barbara Fass (1982), Josephine MacDonagh (1996), Pamela Perkins (1990), Cannon Schmitt (1993).

${ }^{103}$ Readers of this dissertation may note that the same conditions apply to the text examined in chapter three, Charles Dickens' Our Mutual Friend.

${ }^{104}$ Numerous collections appear in the text, including Mr. Fairlie's works of art, Laura and Marian's collection their mother's letters, and the galleries of Blackwater Park (Collins 34, 37, 204). For an explanation of "the disciplinary museum" see Mason 23-24.
} 
encountered in The Woman in White, this list is by no means exhaustive. Before turning to an analysis of the text, the intersections of museum and novel should be elaborated more thoroughly. What follows is an introduction the novel's museual concerns. It will be shown that the museum's ability to make subjects into objects leads to collection and discipline. Ultimately, The Woman in White embraces and replicates the Victorian museum's attitude toward the female body and toward bodies that share the female subject position.

\section{Natural History and The Woman in White}

Having established the museual methods used in the novel, it is proper that The Woman in White be connected to the works of literature examined in the previous chapters. At first glance, The Woman in White may seem more connected to the art museum than to the museum of natural history. ${ }^{105}$ As an artist, Hartright instructs his pupils in drawing and painting, not specimen collecting. However, while Mr. Fairlie's care for his art collection verges on obsession, no great artist resides at Limmeridge House. Instead, The Woman in White, like the novels in the three previous chapters, reveals the influence of the natural history museum.

Hartright's work at Limmeridge House may be linked to the popularization of natural history, a phenomenon that took place between 1820 and 1870 (Barber). ${ }^{106}$ As an art teacher at the estate, he asks his students to capture images of the natural wonders around them, "to sketch from nature" (Collins 17). While drawing was a popular form of rational recreation for young women and part of the curriculum of an upper-class girl, its basis was in the natural history movement, which provided "new subjects for watercolors, for albums, or for embroidery"

\footnotetext{
${ }^{105}$ Another link may be found in Collins' decision to call The Woman in White an experiment in its 1860 preface, a move which "re-describ[es] the method of a fiction writer in terms of the method of a scientist or natural historian" (Erchinger 797).

${ }^{106}$ The events of the novel are commonly dated to 1850 .
} 
(Hughes 71, Barber 16, Kriegel 22). Considered educational, wholesome, and sometimes divine, natural history might shift an activity from mere diversion into the realm of improving one's physical, mental, and moral character. ${ }^{107}$ The natural history art of the nineteenth century has been celebrated for its "vivid colors, specificity of details... biological accuracy" as well as its "considerable visual and emotional impact" (Merrill 164, 168). These qualities are taken at face value at Limmeridge House, where the creation of works based in nature is not questioned by Mr. Fairlie, who hires Hartright, or by his students. ${ }^{108}$ Such creations are naturally accepted as good. Natural history, like the museum, is held out as something that can reform those who engage with it. ${ }^{109}$ It should be noted, however, that the impact of an education in natural history, like the impact of the museum, varied according to gender and class. The women of The Woman in White never take on the active roles associated with the museum such as collection and surveillance. Instead, they remain in the vexed state of subjects who may be transferred, evaluated, authenticated, or collected.

\section{Museual Subjects and Objects}

The Victorian tendency to imbue objects and possessions with human characteristics, emotions, and even actions has been charted by scholars of materiality such as Asa Briggs and John Plotz. In The Idea in Things: Fugitive Meanings in the Victorian Novel, Elaine Freedgood even tackles the typical readerly lament that Victorian novels are too cluttered by things that seem to demand their own say, apart from the dialogue of the characters (1). Through insightful readings of furniture, advertisements, and mementoes, Freedgood demonstrates the connections between

\footnotetext{
${ }^{107}$ See Merrill 39-42 for the benefits of natural history as a teaching tool for children and the working class.

${ }^{108}$ Hartright does turn his back on the powers of Nature for a moment, when "the charm of [Laura's] presence" leads him to value the sight of her figure over "the grandest changes of light and shade" or "the finest view" (Collins 53).

${ }^{109}$ For a discussion of the reforming powers of the museum, see Kriegel 167-170)
} 
subjects and objects and the threat that the two might be interchangeable $(38,47-50)$. For example, in Freedgood's reading, Jane Eyre resists Rochester's attempt to make her into an object of his fancy through decoration. Instead, she marshals furniture that stands for her sense of self, her independence, and her financial freedom (Freedgood 50). In encountering this dark, heavy furniture, Rochester encounters Jane and her determination.

Just as Jane and Rochester are able to encounter the self in objects (or imbue objects with a sense of self), the nineteenth-century museum regarded objects and living subjects in much the same light. Human bodies and body parts could be displayed alongside other specimens, and the Victorians even displayed living beings in human zoos and imperial exhibits at century's end. Such displays were museual in nature, combining education and entertainment, and some even drew on private or public collections to create more authentic experiences (Ward 77). Today, significant controversy surrounds the act of displaying human bodies and bones; the modern museum is embroiled in concerns about ethnicity, cultural voyeurism, cultural superiority, and the theft of native objects by foreign powers (Reigel 89, Karp 12, Waxman 3-9, Cuno 21-43). In the nineteenth century, however, such concerns had not yet become major matters of debate. Just as the museum has its foundations in the scholarly as well as the horrific, the museum both privileges subjects as viewers while making still other subjects into objects that they will view. This binary always includes the threat that the viewer may, in turn, be viewed herself, transformed into the very exhibit that was giving her pleasure moments before. For the Victorians "everything appeared to be an exhibit of itself" including "the city, the body, and the landscape" (Riegel 84). The act of viewing exhibits migrated out of the museum so that "the world outside the exhibit came to resemble an exhibit"; finally "the world" inside and outside of the novel and the people who inhabited it "could only be seen and understood as if it were an 
exhibit" (Riegel 84). In such a world, subjects are always on the verge of becoming objects to be observed, classified, and disciplined. ${ }^{110}$ In The Woman in White, the characters most subject to this threat are the feminized Walter Hartright and the text's female characters.

As subjects who can become objects, the characters in Collins's novel are subject to authentification. An underlying principle of the museum enterprise, authentification ensures that the usefulness and integrity of a collection are preserved whenever a new object is added. In order to be of value to the museum, new acquisitions must meet some educational need, fill a gap in a current collection, or have some implicit cultural or aesthetic value. By excluding some items that do not meet its criteria, the museum cordons itself off from the merely museual spaces which were willing to display objects of curiosity that would draw crowds and coins (Bennett 3). Much of the drama in The Woman in White hinges on Hartright's quest to authenticate Laura Fairlie as an heiress and to restore her to her proper realm of display.

As a subject/object of great value, Laura Fairlie is one of the main "collectibles" featured in the novel and her courtship and marriage highlight Collins's emphasis on the characters' impulses to collect. Though almost all human beings give into such an impulse at some point in their lives (an impulse now made easier to satisfy through the space-saving notion of the digital collection), the act takes a myriad of forms, some of which are even pathologized, and is rarely a

\footnotetext{
${ }^{110}$ One of the characters that does the most to cast light on the museum's influence on the text is also one that the text makes it easiest to mistrust. Conjured (predictably) into the text through a white marble angel, Laura's mother is mourned by Anne Catherick (Collins 87). Seeing the angel with dirt about its base, Anne laments that Mrs. Fairlie should be treated so. Kneeling above the buried form of her lost protector, Anne "touch[es] the hard marble of the cross as tenderly as if it had been a sentient thing" (Collins 98). Because Anne is considered mad, her subject/object confusion is easy to dismiss. However, the act of reading objects as beings and living beings as subjects was a prevalent Victorian fixation. Attributed to the commodity fetishism ushered in by the Crystal Palace Exhibition of 1851, the breakdown of barriers between subjects and objects made it "logical" to "fantasize that physical objects had psychological dimensions," of subjecthood (Richards 19-31, Kriegel 10). For the Victorians, it became more and more difficult to locate the distance "between perceiver and perceived, inside and outside, subject and object" (Chattman 126).
} 
neutral undertaking (Black 22-23). Collecting was not only a Victorian pastime, it also served as one of the primary duties of the museum, culminating in the era of the expedition. In the novel, collection is shown as an act that allows characters to increase their status, display their knowledge and taste, and signal the wealth that permits them to gain a particular object. Female characters often take the role of objects to be collected while men function as active collectors, seekers, and connoisseurs. Once acquired, the connoisseur or collector displays his possessions for private enjoyment or public edification. Similarly, the Victorian museum displayed cultural acquisitions in order to educate its visitors through sight.

\section{Disciplining Subjects/Objects}

Not only did museums conflate the nature of bodies and objects, the museum environment sought to discipline both. While museum objects are catalogued, organized, policed, and ultimately known, bodies in the museum are subject to the observation of other visitors, museum staff, and guards. Such observation, along with the knowledge that one is being observed, trains bodies in the museum in the use of proper behavior and the nature of proper public appearance. The museum's focus on sight made it a natural fit with the work of Michel Foucault and his concept of the panopticon. Recent scholarship has been emphatic in its reading of the museum as a disciplinary space as well as a space in which disciplines are developed and disseminated (Hooper-Greenhill 168, Bennett 63-75). The museum enterprise has been studied

as a civilizing instrument utilized by the state in order to improve its people and as a cultural tool that helped citizens to not only improve themselves but police themselves and others (HooperGreenhill 168, Bennett 59-61).Barbara Black applies the disciplinary function of the museum explicitly to Victorians, noting that "the bodies of the museum visitors became regulated, disciplined by example and by the codes of conduct the museum enforces" (35). A "powerfully 
panoptic" space, "the museums function as a pastiche" of Foucaultian institutions: "madhouse, school, prison, death house" (Black 35). As museum visitors are observed by their fellow visitors and by museum staff, the notion of surveillance is internalized and crowds control themselves, maintaining proper behavior. Further, nineteenth-century museum-goers would have observed visions/versions of themselves on exhibit and internalized hierarchies of gender and race as well as middle class values about health and sanitation.

The Woman in White engages with the museum as a disciplinary space and Collins heightens the effect of constant surveillance by coupling it with the threat of harm. For instance, the female characters in the text (and, by extension, the feminized Hartright) feel that Count Fosco is all-seeing. His presence at Blackwater introduces surveillance to every space in the house and every foot of the grounds. ${ }^{111}$ The threat of observation, embodied in Fosco and, to a lesser degree, in Sir Percival acts as a disciplining mechanism on the bodies of Laura and Marian.

\section{Collectors and Collections}

As a novel set in England in the 1850s, The Woman in White seems an unlikely place to encounter the notion of a person as a collectible possession, unless set down as a criticism of activities taking place across the Atlantic (Sutherland 662-63). This likelihood changes, however, when the novel is read as a work that engaged with museum culture. Museums have a long history of treating people as possessions and of creating collections of bodies or parts of bodies. In his discussion of the culture of the natural history museum, Stephen Asma describes the "monsters" that Tsar Peter the Great "brought to the court as living museum specimens" (3-4).

\footnotetext{
${ }^{111}$ Fosco's abilities are augmented by the use of his wife. With her help, the scheming Count has four eyes on watch
} instead of two. 
Some of these "monsters" even escaped from this exploitative enterprise, effectively reasserting themselves as subjects rather than objects. Of course, Peter the Great was not a Victorian and one might imagine that proper British gentlemen and ladies would react with shock and disgust to his treatment of his countrymen. However, by the end of the century, freak shows, human zoos, and imperial exhibits blurred the lines of demarcation between living subjects and cultural objects (Qureshi 8). ${ }^{112}$ As "an organizational system" that "produce[s]" objects and bodies which may be read, "museums have played a profound classificatory role in supporting diverse nationalist and colonialist/imperialist enterprises" through their ability to "define who is classified as human with rights, who is classified as human artifact, and who is classified as waste" (Musiol 158). Furthermore, museums as part of a society of surveillance were capable of disciplining the body by rendering it knowable through the museums "ability to command, order, and control objects and bodies, living or dead" (Foucault 216, Bennett 66). ${ }^{113}$ The language in this quotation is key; for the museum, objects and bodies are similar and may be interchanged so that human subjects may come to be treated like objects. Similarly, objects in the nineteenth century could be treated like subjects. In the wake of the Crystal Palace Exhibition, commodities were so elevated that they were written about and discussed as if they had sentience (McClintock 57). The conflation of object and subject was not completely new to the Victorians (slavery having existed since ancient times) but the rise of museum culture brought concerns about the mutability of subjects into objects to the fore.

The museum's influence on the wider culture made it possible for the Victorians to perceive objects as subjects. The Great Exhibition, especially, inaugurated an era in which the

\footnotetext{
112 The link between human display and possession of the body was acutely visible to freed African Americans who journeyed to Europe in the middle of the nineteenth-century. In order to draw attention to slavery, spectacles were mounted highlighting the display of the black body and forcing audiences to think of the auction block.

${ }^{113}$ To the verbs "command, order, and control" I would add collect.
} 
"commodity" and like objects could "no longer be viewed as exclusively material form[s]" but began to "appear as independent beings endowed with life, and entering into a relation both with one another and the human race" (Richards 69, qtd. in Richards 68). In The Woman in White, subjects are constantly channeled through a recourse to objects. Anne Catherick becomes so linked to white dresses that the vision of Laura in a white gown transforms her into Laura and sets Hartright trembling (Collins 58-60). When Laura is forced to renounce her love for Hartright, she "bid[s] goodbye" to her album of his drawings "forever" by "lift[ing]... [it] to her lips and kiss[ing] it" (Collins 174). The tender farewell meant for the creator of the drawings is given over to their material container and a watching Marian is as touched and pained as if she had suffered through the pair's parting again (Collins 174). ${ }^{114}$

As noted above, it is not only objects that may be transformed; characters within the novel waver between subjecthood and objecthood and sometimes become completely objectified. Such objectification is primarily the province of the novel's female characters and this state can be most clearly observed in the character of Laura Fairlie. An heiress whose marriage will confer property upon her husband, Laura is always written as more object than young woman. She is the beautiful ornament of Limmeridge House, and she passes through the

\footnotetext{
${ }^{114}$ This tangled and layered relationship between Victorian subjects and the objects they treasured and owned has been described by Plotz as portable property and he defines it as an "obsession" of the "English novel" with "objects represented as problematically endowed with sentimental and fiscal value simultaneously" (7). An example may be seen in Blackwater when Laura welcomes Marian: “ 'Ah!' she cried, clapping her hands with a bright smile of recognition, 'Another old friend found already! Your bookcase, Marian - your dear-little-shabby-old-satin-woodbookcase - how glad I am you brought it with you from Limmeridge! And that horrid, heavy man's umbrella that you always would walk out with when it rained!'” (Collins 214). Laura is greeting her sister in the objects she has transplanted, finding a beloved companion through objects that carry a sense of her self - her portable property. This scene continues with Laura seeking to create a museual space by hanging portraits and arranging "treasures" in order to conjure the past joys of Limmeridge House (Collins 215). Through the positioning of objects, she hopes to restore some part of herself to the girl she was before marriage.
} 
hands of men like a museum treasure. ${ }^{115}$ Everyone who looks upon her is hyperconscious of her value, both monetary and cultural. This value comprises not only her "womanly skills" like piano and art, but "real property" and "her absolute inheritance of personal property when she [comes] of age" (Collins 149). Like the objects catalogued in the Crystal Palace or in the British Museum, Laura Fairlie is a documented treasure, her worth tallied to the last pence. The majority of this documentation enters the text through the account of Mr. Gilmore, the lawyer who draws up her marriage settlement, and the details of Laura's worth extend over three pages (Collins 149-152). These legal documents make Laura into a collectible; they attest to both her worth and authenticity.

\section{The Woman in White}

In The Woman in White Museual concerns about a loss of subjecthood, the perils and pleasures of collecting, and the need to discipline objects as well as bodies come into play as soon as the novel's characters begin interacting with one another. Though clearly the novel's most valuable object, Laura Fairlie is not alone in being perceived evaluated as an object, and it is not for her (mis)treatment as one that the reader initially takes offense. Instead, the reader adventures with Walter Hartright and sees him transformed from a drawing master with an eye to a grand future to a tool to be used at the whim of the wealthy collector, Mr. Fairlie. When Hartright first arrives at Limmeridge House, no threat to his subjecthood is immediately apparent. The letter that welcomes him even declares that he is "to be treated there on the footing of a gentleman" (Collins 16). Yet, in the early days of his arrival, any cultural anxiety that

\footnotetext{
${ }^{115}$ Readers interested in seeing this view highlighted may refer to Rosamond Vincy in George Eliot's Middlemarch. Rosamond is both written as an object and portrayed as a mercenary subject ever intent on gaining more objects. She finally acquires wealth from the death of her husband, another example of the vampiric museum economy at work.
} 
Hartright might feel over the conflation of objects and subjects rapidly morphs into a personal fear when Mr. Fairlie begins using his valet, Louis, as an object to search for, display, and manipulate the art objects he wishes to examine. Seeing Louis used as a display stand for a portfolio, Hartright quickly realizes that he may be put to similar use, his subjectivity and his manhood disregarded. Other scholars have traced Mr. Fairlie's power to his "possession of cultural capital," but his ability to casually curate human beings, to make them over into objects to be used, is far more emasculating to Hartright and far more unsettling to the reader than any cultural capital he might possess (27).

Meeting the wealthy collector for the first time, Hartright's true position at Limmeridge House comes to light. "So glad to possess you at Limmeridge," Fairlie greets him (Collins 40). Initially, such dialogue may be attributed to class or dismissed as a mere pattern of speech. However, Fairlie is clearly contextualized as a museual character. The reader finds him surrounded by "rare and beautiful objects," such as a collection of coins and the materials for polishing them, paintings, portfolios, and etchings (Collins 40, 41). In Fairlie, the reader sees the "manifest[ation]" of the "classificatory nature of the Victorian age"; in his bed, he is at the center of the collection, the exhibit of an invalid framed by the wonders which his wealth has allowed him to acquire (Hallum 31).

Secluded amongst such treasures, Mr. Fairlie expresses a preference for objects over subjects when he admires a Madonna and cherubs and contrasts them to the living children of the village. The former have "[n]o dirty little legs to run about on, and no noisy little lungs to scream with" and so prove themselves "immeasurably superior to reality" (Collins 44). Since Victorian collections can be used to read their collectors, Fairlie can be read as an individual who much prefers the display of the human form in sculpture or painting over dealings with an actual 
human subject (Hallum 32, Black 186-196). Repeated at the end of his interview with Hartright, Fairlie's words, "So glad to possess you" suggest the addition of a desirable object to his vast household. Hartright has been acquired. Both his "gentlemanly rank" and his "economic wealth" allow Fairlie to "possess" Hartright; he can purchase a man below him in class and in status as easily as he can purchase a new print. In a house where the master has such abilities, Hartright's status can never be completely stable. He is always in the position of a man who may, at any time, be regarded as an object. Like Laura, Hartright is a possession in Limmeridge House. Yet, while Laura is destined to be exhibited in an estate, the best that Hartright can hope for is to be brought into a well-paying household as an instructor but never as a member of the family.

He is a tool - an object - that will be used to better other objects to be put on display. Fairlie makes clear this view when discusses his valet: "What can you possibly mean by calling him a man?" he asks. He declares, "He's nothing of the sort. He might have been a man half an hour ago, before I wanted my etchings; and he may be a man half an hour hence, when I don't want them any longer. At present, he is simply a portfolio stand" (Collins 159). Readers will, of course, remember that Hartright was brought to Limmeridge "on the footing of a gentleman," but his first interview connects him to the unfortunate valet when he takes up a portfolio and Fairlie notices and admires his ability to carry it with the comment, "How nice to be so strong!" (Collins 44). Like the servant mentioned above, while he is employed by Fairlie, Hartright is ever in danger of being perceived as more an object than a subject. Also, his is a "profession in which the sign of his class difference is his desexualization"; at Limmeridge his work is "a pecuniary arrangement in which his chastity, as much as his artistic prowess is being purchased" 
(Cvetkovitch 28, McKelvy 300). Hartright is unmanned by his employment as well as threatened with objectification. ${ }^{116}$

Occupying the unenviable position of objectified and feminized drawing master, Hartright sets his sights on the lovely Laura Fairlie, Limmeridge House's most valuable collectible. When the story of Hartright's rescue of Laura is read through a museual lens, his motivations and his decision to commit the tale to paper are illuminated. Hartright's story is the case study of a collector. He sees a valuable object, he desires it, and he struggles for several hundred pages to acquire it. Upon acquisition, he is then remade in light of the thing he now possesses. Before the drawing master even begins his quest to collect Laura Fairlie, he is already seen as a man fit to care for a valuable collection. Tasked with mounting and restoring Limmeridge's treasures, Hartright begins the work that will culminate in "sun-pictures of all the curiosities and treasures in [Fairlie's] possession" (Collins 201). These photographs are then "to be presented to the Mechanics' Institute of Carlisle," a museual institution, "mounted on the finest cardboard with ostentatious red-letter inscriptions underneath" (Collins 201). Fairlie's name will adorn each photograph. By displaying the collection to the Institute's audience, "Goths and Vandals to a man," the collector broadcasts his reputation as a collector and connoisseur to the wider world (Collins 346). ${ }^{117}$ The care and preparation of this collection falls to Hartright. Paintings, coins, and fine art are not the only objects that Mr. Fairlie must look after. He sees his two nieces, Laura and Marian, as possessions, too, "dreadful responsibilit[ies]" which have come under his care through inheritance until a particular transaction (marriage) will place them under the care of someone else (Collins 352). Besides seeing to Fairlie's art, Hartright is also tasked with

\footnotetext{
${ }^{116}$ Hallum reads Fairlie as "the typical mid-Victorian impression of aristocratic masculinity in his weak, effeminate, and non-procreative conduct" (33). Fairlie may have these characteristics but he retains the ability to transform Hartright into something less than a man.

117 The reference to such an institute is also a minor museual moment within the text. For a discussion of manner in which museums and Mechanic's Institutes influenced one another, see Kriegel 19-51.
} 
instructing these young ladies, polishing them and looking after them until the proper collector comes to call.

Hartright's position makes it impossible for him to play the role of collector to the beautiful object that is Laura Fairlie. Although he is marked as a natural gentleman for his treatment of the woman in white, Hartright does not fit the novel's profile of the gentlemanly collector, so Laura is beyond his means to care for or ever collect (Collins 70). The reader is shown examples of such collectors in Laura's deceased father and Sir Percival Glyde, landowners who possess private estates. Such estates are the origin places of the museum and both are places where a beautiful woman may be displayed. ${ }^{118}$ As museual spaces, these estates were often decorated with ornaments that one might find within the museum proper: paintings, sculpture, hunting trophies, and even fossils. Walter Hartright may produce beautiful objects in the form of his paintings, but he is "not a man of rank or title" and so cannot collect the beautiful objects that Laura Fairlie should take her place among; despite his skills and his desires, "he initially lacks the economic and social capital required to have an artistic collection of his own" (Collins 24, Hallum 39).

As a beautiful object meant to be displayed among a collection of beautiful objects, Laura must be acquired or collected by a man who is capable of affording her, a situation similar to that of Bella Wilfer described in chapter three. As a "luxury" item, with the "specialized" training of an upper class woman, "[s]he requires a level of maintenance that could only be provided by someone with a great deal of discretionary income and a certain background" (Balkun 75, 74). ${ }^{119}$

\footnotetext{
${ }^{118}$ House museums, like that of Sir John Soane, helped to popularize museum catalogues and encouraged middle class visitors to create collections within their own domiciles, even if the entire house could not be made over into a museum. Also, estate houses often boasted items that appeared in museum collections.

${ }^{119}$ Balkun's scholarship centers on American literature. However, the commodification, issues of authenticity and other museual concerns she touches on appeared in literature on both sides of the Atlantic.
} 
Her "acquisition... guarantees to its possessor social property," but a man in Hartright's position has no hope of securing her (Cvetkovich 40). Though she may not wish to marry Sir Percival Glyde, Laura is not ignorant of her position in the world; her entire life and her education have prepared her to marry a man of her class. Marian Halcombe makes the unsuitability of the match clear when she gives thanks that Laura's engagement "spare[s] [her] the ungracious necessity of paining... [Hartright]...by any humiliating reference to rank and station" (Collins 71). The drawing master is asked to leave not because of his profession, but because of a prior proposal. However, he, Marian, and the reader are all aware of the fact that rank and station would have interfered if the engagement had not.

In order for objects like Laura Fairlie to be collected, their value must be attested to they must be authenticated. ${ }^{120}$ In life, Laura's value is unquestioned, but much of the novel revolves around the authentification of her "dead" body once Fosco and Percival's scheme to acquire her fortune has been set in motion. ${ }^{121}$ The plan incorporates many museual motifs. The substitution of the body of Anne for that of Laura is a case of counterfeiting: replacing a valuable treasure with a fake that shares its qualities. In order for this to work, the schemers must call in an expert on Laura to read and evaluate her body - to assign it a stamp of authenticity. ${ }^{122}$ This stamp is given by Dr. Alfred Goodricke whose narrative exists within the novel as an official

\footnotetext{
${ }^{120}$ That the concern over authenticity migrated out of the museum and into the larger Victorian culture may be seen in the fact that issues of authenticity and counterfeiting haunt novels like: William Thackeray's Vanity Fair, John Galsworthy's Man of Property, and Charles Dickens's Our Mutual Friend.

${ }^{121}$ Laura's value may be seen through the concept of the museum economy discussed in chapter three. The idea of value deriving from death is made very clear in the novel by the Solicitor Vincent Gilmore, who draws up Laura's marriage settlement. Over the course of several pages, Gilmore traces the manner in which Laura's fortune has come to her. The story is one of value deriving from death. In two paragraphs detailing the Fairlie fortune, the word "died" appears six times (Collins 149). The words "decease," "drowned" and "death," also appear (Collins 149). The value contained by Laura has come to her through the destruction of other bodies, the various branches of her family tree. When Gilmore goes on to discuss Laura's property with her, death also haunts this conversation. The question at the heart of it is where Laura's money is to go if she is to die before her husband, a question her uncle considers "the very last thing in the world that is likely to happen" (Collins 162).

122 The idea of value out of death has already been discussed in earlier chapters; the sinister motif outlined by Collins may even be a source of inspiration for Our Mutual Friend.
} 
document attesting to the death of Lady Glyde (Collins 413). Such a document authenticates Anne Catherick's corpse as Lady Glyde even as it turns the real Lady Glyde, Laura Fairlie, into a counterfeit of herself!

The death certificate is then seconded by another narrative, a tombstone whose inscription is copied into the text - a museum plaque of sorts that points to the whereabouts of the remains of the late Lady Glyde. Laura is then divided between remains, which bear her name, and her new identity as Anne Catherick. Like the museum, Percival and Fosco destroy a living body (Laura) so that they may exhibit it in death and claim its value (Asma 30-32). Like animal exhibits prepared for display, Laura (and Anne as Laura) is sought, captured, transported, subjected to suffering and finally death, authenticated, and displayed so that her value may be declared (and ultimately transferred to Percival). Once this transformation has taken place, Laura is transported to the asylum to take her place as Anne. In this new form, she no longer possesses any value and can be exported from her former showcase. Only her authenticated body must be displayed in order for her wealth to pass to the schemers.

Once acquired or collected, bodies and objects were subject to disciplinary measures. The destruction of Anne Catherick and commitment of Laura Fairlie to an asylum are extreme example of disciplining the female body (often figured as an object). While Collins's novel takes the concept of discipline to the extreme, the surveillance and discipline of female bodies was a primary concern of the Victorian museum. The atmosphere of surveillance that operates to discipline female bodies in the novel is a direct inheritance of the Victorian natural history museum. Within a museum environment, bodies often featured in exhibits meant to encourage healthy living and were judged as hale and strong or ruined by sloth or indulgence (Black 34). 
Other exhibits perpetuated and disseminated hierarchical and often Darwinian views of male and female bodies (McClintock 37, Asma 253).

As "the exemplary institution for embodying the Victorian narrative of progress," the museum was a site that presented hierarchies of race, class, and gender. Within these displays, the female body was shown to be inferior to its male counterpart, an example of "an inherently degenerate "race"" (McClintock 54). In racial exhibits, especially, the white female body acted as a sort of delicate barrier between that of the white male and the so-called lesser races, the criminal, and the insane (McClintock 55-56). The location of the white female body, between the upper class male and the Irish and Jewish male, visually suggested that women were nearer to madness than men and, therefore, more likely to be infected/affected by it (McClintock 56). Hartright projects this view in the novel when he insists upon seeing the female body as delicate and easily conquered by disease and the female mind as irrational and easily conquered by emotion. Take the example of Laura Fairlie, whom he urges the reader to conjure up as his "visionary nursling" (Collins 50). Laura is described as "a fair, delicate girl" with "innocent blue eyes"; she is a creature to be looked after and instructed, to be spoken of ever in the diminutive (Collins 50). Hartright's view would not have been out of place in either Victorian culture or the Victorian museum, where women were often perceived as child-like, if not outright children.

The view of women as infantile is reinforced in the novel by Count Fosco, who notes that women "are nothing but children grown up" (Collins 330). The museum sustained this ideology through science and through exhibits such as those that emphasized the small size and small skull of the European female. The latter was a nineteenth-century sign for an underdeveloped intellect, supporting the argument that women were not capable of higher order thinking. This was supported by data which "showed that women's smaller brains were analogous to the brains 
of the lower races, the small size explaining both groups' intellectual inferiority" and being linked to women's "social inferiority" as well (Stepan 270). The production of such knowledge within the scientific sphere supported social and cultural attitudes about women. Female bodies were thereby disciplined into particular "ladylike" modes of behavior because the enterprises that championed such behavior (guidebooks, newspaper articles, etc.) had their backing in scientific Truth.

At Limmeridge, Hartright shows Laura as a perfect example of womanhood, a childlike creature who benefits from his care and instruction. Hartright informs the reader that Laura speaks "prettily and simply” as a schoolgirl reciting her lessons, her words accompanied by “a quaint, childish earnestness" (Collins 51). As the protagonist and voice of male authority in the narrative, Hartright's views can be taken as indicative of a wider culture. The reader sees the reach of such ideas when he or she considers the size of the text itself. Because Laura Fairlie is a woman (and a woman whose body and mind have been subjected to severe trials) she cannot be believed on her own. In the wake of Percival and Fosco's fraud, she cannot assert her identity. Like a fossil remnant that has surfaced or a piece of art that resembles the work of a master hand, Laura must be authenticated through several hundred pages of narrative, letters, and testimony, all of it arranged by Hartright. The opening lines make Laura's position very clear by identifying the story as one of “what a Woman's patience can endure, and what a Man's resolution can achieve" (Collins 5). The unidentified woman (Laura Fairlie) clearly occupies a passive place. ${ }^{123}$ Her return to a world of privilege can only be "achieved" through male agency.

\footnotetext{
${ }^{123}$ Gaylin reads this "preamble" as one that "asserts that gender roles [within the text] are fixed and absolute," a position that would have been supported by the views of gender perpetuated by the museum (306).
} 
Indeed, The Woman in White can only function as a narrative if its readers accept Hartright's (and the museum's) view of female frailty, a frailty exhibited in each of the major female characters within the text. Anne Catherick acts as a case study, quite literally, of a damaged feminine psyche, a woman so obsessed with a small act of kindness done to her as a child that she has built her adult appearance around it. As a child, Anne was given "Laura's old white frocks and white hats" after Mrs. Fairlie "explain[ed] to her that little girls of her complexion looked neater and better all in white than in anything else" (Collins 59). Upon receiving these garments, Anne declares that "I will always wear white as long as I live" as a show of gratitude and remembrance (Collins 59). As an adult, she has not left off her "old grateful fancy of dressing in white"; her physical appearance becomes a tribute to the departed Mrs. Fairlie and physical evidence of her mental state (Collins 60). The combination of her gender and her mental frailties lead Hartright to read her as "an unfortunate creature, whose actions it was [his] duty, and every man's duty, mercifully to control" (Collins 29). Anne's is a body to be disciplined. Throughout the text, Anne will be read as "deranged," possessed of "queer whims and ways," "childlike," "disturbed," "dangerous," and "with a touch of something wrong in her head," "crazy," and an "idiot" (Collins 80, 94, 10, 101, 131, 156, 549). The woman dressed in white becomes a sign of female feebleness and of the easily bewildered female mind. Anne is also cursed with illness, a serious condition of the heart, which is itself a sign of the weaker female body. Positioned below men in the social and racial hierarchy, a hierarchy reflected in museum exhibits, the female body was associated with lack and with disease, as well as with weakness and frail health (Gilbert 66, van Dijk 3064).

Though she lacks Anne's childlike mental state, Laura also serves as an example of feminine frailty within the text. The first glimpse of Laura in the text is actually an absence; she is missing 
due to that "essentially feminine malady, a slight headache" (Collins 33). Her physical weakness is paired with emotional frailty. When she begins to develop feelings for Hartright, she displays distress through nervous movements, through "wretched[ness]," and through "suffering" (Collins 68, 72). These emotional responses are tied to her gender, read as indicators of "delicate, womanly taste" (Collins 63). However, they may also be read as indicators that women are less reasonable than men, less in command of themselves, and more in need of societal (male) discipline. Laura is equated with excessive emotionality several times throughout the book. When she receives a letter of warning from Anne Catherick, Laura becomes so "agitated and alarmed" that Marian can barely leave her side (Collins 77). Her feelings for Hartright affect her physically as well as mentally, causing her fingers to go "cold" and "tremble" and causing her cheeks to "burn" with "a bright red spot" (Collins 120). Marian counsels Hartright to leave in order that Laura's “old calmness and old contentment" will return (Collins 72). Laura is so ruled by her emotions that she confesses her love of Hartright to her husband, a man who will only use such honesty against her (Collins 165).

Most telling of all, Hartright connects Laura directly to Anne when he notes a "sense of incompleteness," "a strange sense of something wanting" which turns out to be the fact that Laura and Anne look like "twin-sisters of chance resemblance" (Collins 51, 54, 97). Besides being actually related to one another (Laura and Anne are half-sisters) the two are members of a sisterhood of women; their similarity implies that any member of the group may suffer that which afflicts one of them. Similarly, by exhibiting specimens of female frailty, weakness, or "diminished" intellect, museums suggested that these examples stood for all women. The echo of Anne in Laura's features suggests both that female bodies share essential natures and one may be read as a key to all (a practice embraced by the museum) and that their minds, too, may be alike. 
Finally, later in the text Laura will be so degraded by suffering, her "intellects [sic]" so "shaken by the horror of what she has been subjected to that both Marian and Hartright can gently lie to her about their everyday circumstances and be believed (Collins 430, 442, 489).

It may seem that Collins offers something of a counter to the typical view of Victorian womanhood in the character of Marian Halcombe, Laura's devoted sister. ${ }^{124}$ However, though Marian may carry a man's umbrella, she still finds herself constrained by the traditional narrative of what it means to be a woman in the nineteenth century. Her physical appearance, her lack of property, and the way that her gender has been socialized all throw up roadblocks for her; the view of women as "the most inferior forms of human evolution" remains dominant not just in the museum but in the novel (qtd. in McClintock 54). Not only inferior as a "form" of evolution, Marian is marked as inferior in form. When she enters the text, she is immediately identified as ugly (Collins 31). The mismatched nature of her masculine face and feminine form is described in language befitting the freak show, and the mere sight of her causes a "sensation oddly akin to the helpless discomfort familiar to us all in sleep, when we recognise [sic] yet cannot reconcile the anomalies and contradictions of a dream" (Collins 32). ${ }^{125}$ Marian knows that her physical appearance limits her options, describing herself as "dark and ugly" to Laura's "fair and pretty" (Collins 34). Embracing her lot in life, she takes on the title of "Marian Halcombe, spinster" (Collins 198).

\footnotetext{
${ }^{124}$ Marian is a far more engaging character than Laura. She fights against the constraints of her gender rather than succumbing to a nineteenth-century narrative of who she should be. She has even been revived in modern fiction in James Wilson's The Dark Clue (2001).

125 The use of the language of freakery to describe Marian is also extended to the foreign and exotic Professor Pesca, described by Hartright as "the smallest human being I ever saw out of a show-room" (Collins 7). Furthermore, the figures in show-rooms, especially at the end of the century, were often colonials, subjects made over into imperial objects. Collins connects Pesca to these exhibits when he has Hartright comment on the Professor's attempt to "turn himself into an Englishman" (7). As a freakish character, Pesca cannot be entirely and properly English. Hennelly connects him to "Dickens' self-crippling grotesques like Jenny Wren in Our Mutual Friend," a character discussed in chapter three (458).
} 
Marian's physical appearance combines with her lack of fortune to limit her socially. While her half-sister Laura is an heiress, Marian is the daughter of "a poor man" (Collins 34). All that she possesses in the world fits in "three boxes and a bag" (Collins 198). Because of the love she bears for her sister, Marian stays with her "in the humdrum atmosphere at Limmeridge House" at the cost of losing all other society but that of Mr. Fairlie, and later follows her to Blackwater Park, to London, and finally back to Limmeridge (Collins 35). She knows that she will probably never marry or have children; she has been raised and educated as "a highly-bred woman" but she possesses no fortune (Collins 32). This is a role she will accept and even relish by the finish of the book, when she rejoices in her future as the aunt to Laura's children (Collins 637).

What Collins does present in Marian is a figure that is aware of discrepancies based in gender, a character who laments her misfortune at being born into a body that institutions like the medical establishment and the museum read as inferior. Throughout the text, she strives to prove that she can be worthwhile to Hartright as an ally despite her gender, demonstrating her knowledge of patriarchy (Collins 48, 448). She also laments her lack of agency through phrases such as "If I had been a man, I would have knocked him down on the threshold of his own door" and "my hands tingled to strike him, as if I had been a man!" (Collins 249, 559). These and several other instances throughout the text show that Marian is aware of her secondhand status, and sometimes resentful of it (Collins 200, 225, 326, 597).

Not only did the museum teach the Victorians to read the female body and to assign it to a position below the male body, it also "yielded... a citizenry" which would "civilize themselves" through the use of exhibits as "props for a social performance" (Bennett 47). That is, museumgoers would watch, be watched, and internalize proper middle class behaviors through the pressure of surveillance. As the lower and working classes entered the hall of the muses, the 
upper and middle class patrons expressed concerns over their behavior and over the safety of the museum's displays. This concern can be seen in the October 4, 1916 issue of Punch, albeit satirically expressed (see figure 1). In the cartoon, a misbehaving (lower class) patron must confront the surveillance marshaled by the museum, surveillance represented by the police and supported by the full weight of the legal system (Bateman 133). The cartoon is hyperbolic, of course, but Victorian museums did take precautions in the form of guides, cordons, and police. As the century wore on, outward manifestations of surveillance began to fade as museum-goers became watchers of one another.

In Collins' novel, the museual task of surveillance is not taken up around Fairlie's beloved coins (though one suspects him of counting them each morning to make sure that all were present) but around the female body, a body that the museum envisioned as existing "outside" of the history of man (Bennett 46). This is most explicit in the case of Anne, who is first seen seeking to evade the scientific/medical community who wish to confine her to the asylum. Collins often assigns the task of surveillance to the less savory characters of the novel. Chief among these is the mysterious Count Fosco, a creature so strange and exaggerated that he becomes a sort of living exhibit to Marian, who documents his menagerie of animals, his corpulence, and his costumes. Though Percival Glyde is capable of quiet menace, the Count's vision is to be feared. He is thought to be almost omnipotent, a fact Collins highlights when he aligns this character with a secret society. Marian and Laura believe that the Count knows all that happens at Blackwater; he has access to their written communications, even Marian's private diary (Collins 295).When Marian undertakes the act of surveillance, spying on Percival and the Count, her victory is usurped by Fosco's acquisition of her diary. ${ }^{126}$ Adding to her record of her

${ }^{126}$ For a discussion of the diary's seizure as narrative rape see Gaylin 317-318 and Miller 116. 
private thoughts, he demonstrates the range of his control even as he praises her for "the excellence of the stratagem by which this unparalleled woman surprised the private interview between Sir Percival and myself" (Collins 344). Women may be able to undertake surveillance at Blackwater, but Fosco remains the master of it.

Surveillance in The Woman in White functions much like surveillance within the museum. Valuable things (women in this case) are meant to stay in their places. Steps are taken against theft or loss (Laura's affection for Hartright seems a true threat to Glyde, for instance). Proper behavior is enforced at all times. Such surveillance is enacted precisely because of the value that Laura possesses. The museum may assign her a place below Sir Percival Glyde in an evolutionary exhibit, but her fortune makes her a valuable commodity to the indebted lord. When she refuses to transfer this value to him, Glyde works out a scheme that incorporates the museum economy discussed in the last chapter. If Laura's value cannot be reaped while she is a living woman then Glyde and Fosco intend to collect value from her as a dead object. Her body will be read, evaluated, and made to pay out the money that she will not yield in life. ${ }^{127}$ Glyde even hints at this when he and his wife view artworks, ruins, and tombs in Rome. There he says that "If I do build you a tomb... it will be done with your own money," indicating that her value can only be fully appreciated upon her death (Collins 262). ${ }^{128}$

While Percival and Fosco are clearly designed as antagonists, the novel's hero cannot be exempted from those individuals who engage in the museum's methods of surveillance.

\footnotetext{
${ }^{127}$ Fosco is connected to the museum's economy of value-through-death through his invention of "a means of petrifying the body after death, so as to preserve it, hard as marble, to the end of time" (Collins 223). When one considers what experiments such an invention might have grown out of, one again confronts the unsettling side of the museum enterprise.

128 This scene may be linked to another honeymoon with museual undertones, that of Dorothea and Causabon in George Eliot's Middlemarch. While the two are in Rome, Dorothea is transformed into a work of art by the narrator and Causabon is desired as a model for a painting.
} 
Hartright takes on the position of critic and collector, and his keen eye is not reserved for paintings alone. ${ }^{129}$ From almost the first moment that Hartright is introduced to the reader, he reveals a tendency to observe and assess the female body. In a single paragraph relating to Anne Catherick, Walter "look[s] attentively," makes an effort to "discern" her features, and undertakes to "observ[e]... her in the dim light" (Collins 20-21). Marian Halcombe and Laura Fairlie will undergo the same sort of observation at Limmeridge House. Critics have rightly read these moments as male gaze, moments in which the passive female body is read and then (often) coded with desire (Caselli 159, Hallum 41, Culbertson).

The concept of male gaze may be expanded and complicated when one considers that such scopophilic moments are also museual ones. In the museum, vision is used not only to express only desire, but to assess, authenticate, and to assign value to the female bodies it encounters. Critics have also linked the scopophilia of the sensation novel to functions of "surveillance" as well as to the realm of the "pornographic" that "at least in Victorian terms" also "needs policing" (Brantlinger 160). Surveillance and discipline coupled with the pleasures of gazing are the functions of the museum, which welcomed viewers to gaze on objects in order to discipline themselves by absorbing the lessons such exhibits contained. Hartright's gaze is a museual one, as may be seen in his observation of Marian Halcombe. When he first encounters Marian, she is turned away from him and he "allow[s]" himself "the luxury of admiring her for a few moments" (Collins 30). Having only seen the back of her, he judges her to be "tall, yet not too tall" and "well-developed, yet not fat," value judgments that indicate that she meets particular standards of feminine beauty (Collins 30). Marian appears to be a perfect specimen of her gender; as a lovely

\footnotetext{
${ }^{129}$ Marian and Laura recognize that assessment and judgment are a part of Hartright's function at Limmeridge House. Collins signals their awareness when he gives the following piece of dialogue to Marian: "Good, bad, or indifferent, ... the pupil's sketches must pass through the fiery ordeal of the master's judgement" (Collins 52). For a discussion of Hartright as a bourgeois collector, see Hallum.
} 
and proportional figure, she may stand in for fair womanhood (Pacteau 78). As she turns, Hartright is thrown into "a flutter of expectation to see her face clearly"; he sees nothing wrong with his scrutiny or in assigning value to her looks (Collins 30). Hartright shows himself to be part of a world influenced by the museum, a cultural artifact that taught viewers the art of perception, an art that "bec[ame] inseparable from perceiving... value" (Richards 64). Hartright's engagement in such practices indicates that he embodies the beliefs propounded by the natural history museum.

Hartright's assessing gaze, "his... desire to judge, categorize, and sentence women," both implicates the museum as a patriarchal institution and indicates that its reach was broad enough to influence the content of the sensational novel. ${ }^{130}$ Indeed, Collins' museual references are key to his intentions - creating emotional sensations in the reader. Like Dickens, Collins was aware of the inherent creepiness of museums, their foundations in death and the grotesque (as discussed in chapters one and three). By summoning the museum into the text, Collins also calls on these associations. In a culture where the museum was an important and influential structure, these connotations would have been easily accessed and understood by a Victorian reading public.

Beyond mere surveying and surveillance, Hartright will also prove capable of using the culture of the museum to change his fortunes. Prior to Laura's transformation into Anne, Hartright is objectified by Mr. Fairlie, policed by Marian because he is an improper suitor, and rejected as a potential collector of Laura. In order to change his status, Hartright joins an archaeological expedition (a museual expedition) to "make excavations among the ruined cities

${ }^{130}$ Hartright often creates tableaus for the reader which may contain one sister or both. See Collins 48-49, 55, 96. 
of Central America" (Collins 180). ${ }^{131}$ Several critics have read this journey as a critical turning point in Hartright's characterization, though none have linked it to the museum (Gaylin 313, Hallum 42, Williams 99-100). Hartright's “imperial adventure," complete with wilderness, attacks by Indians, plague, and shipwreck, may help him to become a more mature and traditionally masculine character, but this would not be enough to overcome the class and social boundaries between him and the woman he so desperately wishes to possess (Gaylin 313). When the novel begins, Hartright is in the unenviable position of a man who may become an object, a man who shares many characteristics with his female charges. His love for Laura and his knowledge of the distance between them places him in a "position of helplessness and humiliation" (Collins 66). While museual work was often envisioned as an occupation that might offer salvation, the expedition does not complete Hartright's evolution from object to connoisseur. In the world of The Woman in White, women operate as objects which confer value upon those who possess them. In order to change his status, Hartright will have to prove himself capable of securing and providing for such an object (subject). Laura's downfall is what makes his rise possible and permits him to tell a "story" that both details his acquisition of Laura and "serves as a vehicle for his ascension to patriarchal property and power" (Cvetkovich 25). Embracing the museum's vision of the frail Victorian woman who must be protected and provided for, Hartright sets out to authenticate his love and win back the trappings of her former position.

In her new identity, Laura Fairlie is part Laura and part Anne Catherick. She possesses the memories and affections of Laura, but her new physical shape and financial situation align her

\footnotetext{
${ }^{131}$ It is worth noting that Hartright would not have been able to take part in this expedition without the help of Marian Halcombe. He "implores" her to use her influence to secure him a chance to work "among new scenes and new people" (Collins 157, 167-68). Her upper class position allows her to assist him.
} 
with Anne. In this new guise, "with every worldly advantage gone from her[,] with all prospect of recovering her rank and station more than doubtful," she becomes accessible to Hartright (Collins 575). ${ }^{132}$ Early in the text, his ability to woo her is openly discounted, even though he and Marian mistrust Sir Percival. She is far too valuable for a mere drawing master. However, physical changes so lower her value that he can acquire her, just as if she were a valuable museum piece that sustained water damage.

Just as he was able to extend a form of aid to the real escaped Anne Catherick, Hartright can now play the rescuer of the false Anne Catherick. He delights in his position as the man "to fight her battle, and to win the way back for her to her place in the world of living beings" (Collins 421). His wages, however meager, can provide her with shelter and food which she cannot access on her own as a woman recently escaped from the asylum. In this new position, Hartright can claim that "she was mine at last! Mine to support, to protect, to cherish, to restore" (Collins 422). In so museual a text, the last is worth pausing on. With Laura, the reader sees Hartright doing exactly the same sort of work he did at Limmeridge House. There, he took faded prints in disrepair and restored them to their former state of beauty. With Laura, he has found a treasure that must be similarly repaired and restored to her rightful surroundings. With the help of Marian, he acquires "strengthening food" for her, helps her regain her strength with walks, and "compose[s] and stead[ies] her" all "without her help" (Collins 444). Laura cannot aid in her own restoration because of the trauma she has endured; Hartright must be the one to put her back together. The agency in the tale of her remaking belongs completely to him and she becomes an object given over to his care. In her changed state, she is completely patronized by him, written as "faltering," "feeble," easy to "confuse and alarm" (Collins 442, 443). If Laura was once read

${ }^{132}$ Taylor reads the novel as a "fight over how to possess and repossess" Laura, language which further indicates her object status (52). 
and assessed by Hartright as womanly (read delicate and childlike) this reading is reinforced once she escapes from the asylum and it is a reading that reinforces the text's exhibit of female frailty. This frailty may abate only partly, but once Laura is restored to her social position, her value will be conferred upon the man who restored her. Proving himself the ultimate collector in a museual culture (a collector who knows the value of Laura when no one else does) Hartright crafts "a fantasy of male self-invention that posits women as the objects and vehicles of that self invention" (Ablow 174). People will know that it was the skill and craft of the "poor drawingmaster" that brought out the beauty he describes in the first pages (Collins 575). Indeed, the work of Laura's restoration may be seen as the motivation for the entire book. Like those adventurers who returned with treasures from new imperial holdings, Hartright is describing his trials in recovering Laura. In remaking her he also remakes himself. As the restorer of Laura and the only one who could see her value when she was disguised, Hartright secures his reputation and his status. Through her, he will become the master of Limmeridge House and assume "possession of all of Fairlie's treasured artistic objects" (Hallum 43). Hartright will come to rule over the museual space that once threatened to make him into an object.

In The Woman in White, museual forces redeem a drawing master and unite him with the great love of his life. Fittingly, the conclusion of Collins's novel takes place in the days of the Crystal Palace Exhibition and readers can almost see the glint of its glassy walls as this great Victorian museum exerts its influence on the text. Not only does the inclusion of the Crystal Palace further the plot by helping to explain the movements of Count Fosco, the proto-museum acts as a cultural marker that points to the importance of the museum in Victorian culture 
(Collins 578). ${ }^{133}$ This culture, inaugurated by the Crystal Palace, girds the most well known of the sensation novels with cultural allusions and connotations which make for a rich, complicated, and eerie read in tribute to those important Victorian structures, themselves rich with objects, complicated in narrative, and resting on eerie foundations of grotesquerie.

${ }^{133}$ Fosco is further linked to the museum when he donates his creatures (all except for the mice) to the zoological gardens, another museual institution and when his body is made a spectacle of in Paris (Collins 611). 


\section{Coda: Return to the Crystal Palace?}

Imperial exhibitions, world's fairs, and human zoos would continue to draw crowds through the end of the nineteenth century. Unlike the museum proper, these institutions also drew a great deal of criticism for their display of living bodies, their imperial agenda, and the use of racial and pseudo-science to underpin their messages. While this study does not focus on these late-century museual spaces, it has demonstrated that the museum already possessed its own share of negative traits. Imperialism, the privileging of the middle and upper classes, racism, sexism, and the destruction of bodies have been shown in these chapters to be integral parts of the nineteenthcentury museum despite its messages of uplift and positivism.

In chapter one, the museum was shown to be grounded in the grotesque as well as the intellectual. Just as readers of The Old Curiosity Shop find Daniel Quilp a more compelling literary creation than Little Nell, so nineteenth-century museum-goers often needed some promise of spectacle to lure them into the museum's halls of learning. Further, the museum enterprise's attempts to separate itself from popular entertainments in which the grotesque was often on view failed as fairs, demonstrations, and freak shows borrowed its tactics and its authority. The second chapter reveals that the museum is not only grotesque but nationalistic, while at the same time being blind to the fate of its poor and working class citizens. Henry Mayhew's London Labour and the London Poor also shows how the museum's scientific methods of organization may be exported into the world and used to organize individuals classed as undesirable, such as the criminal and the poor. Chapter three outlines the dark economy operating in the natural history museum, wherein bodies may be destroyed in order to render them more valuable as specimens. Our Mutual Friend draws almost every character into this 
economy, in life as well as in death, and makes the larger world a museum space of display, collection, observation, and exhibition. The final chapter demonstrates the place that racial science and sexual science held within the museum and how the museum worked to discipline both bodies on display and bodies that came to observe. These chapters make it clear that much that came to be criticized in the imperial exhibits and human zoos was already nascent in the museum; the Victorian museum already had two faces.

The dual nature of the museum remains a concern, because, today, almost every major urban center in the world boasts some form of museum. Throughout the world, many of these stately cathedrals of learning are also monuments to the British Empire, built in order to exhibit the natives to themselves and to make the world more knowable to their British conquerors conquerors who had learned the museum's tactics and power in $1851 .{ }^{134}$ Today, schoolchildren on day trips and gawking tourists pass through these halls without noting their legacy and without imagining that museums were once conceptualized differently. That the visits continue and that funds continue to be voted for or funneled toward the museum marks its triumph and its position as a Victorian survivor when so much else has been lost.

Among the things lost to the museum following the nineteenth century was the positivism and belief in progress that marked the Victorian era. Crowds entered the Crystal Palace in 1851 and believed that the entire world could be seen and known and grasped - literally touched - because the entire world had been piled up under glass for them to observe. This knowledge was then meant to translate into affordable products that improved health, elevated manners, eased manual labor, increased general knowledge, and beautified Victorian homes. Certainly, some of these

\footnotetext{
${ }^{134}$ While the conquerors are gone, British museums are still seeking to control the historical narrative. In 2013, curator Neil MacGregor published A History of the World in 100 Objects, a history told through objects on display in the British Museum. The problematic ownership and contested state of these objects is noted by MacGregor, but there is no discussion of relinquishing them.
} 
results came to pass, but the Victorian museum was never able to completely remake its working classes just by getting them inside of the museum. Instead of a working class that chose the museum over the public house, the end of the nineteenth century saw a working class that might spend the day at an exhibition and then visit the public house before returning home. Of course, modern readers may be forgiven their smirk and any murmuring they wish to do about the Victorians and their overoptimistic view that rows of skeletons, taxidermied animals, and comparative exhibits might work such wondrous changes. While the Victorians that believed in the social mission of the museum may seem childishly hopeful to modern readers, it is important to remember that the end of these hopes was anything but childish. The same methods of cheap manufacture popularized by the Great Exhibition of 1851 allowed for the mass production of weaponry in the years leading up to the Great War. The Victorian belief in progress through material improvements ended when it became possible to produce bullets faster than men could be found to kill with them.

Literature reflects this loss of faith. In a "gallery of readings," Barbara J. Black demonstrates that late-Victorian literature showed the museum in a state of decline. Her analysis focuses on William Morris's News from Nowhere (1891), H.G. Wells's The Time Machine (1895) and John Galsworthy's Forsyte Saga (1906), of which an in-depth museual reading has yet to be done. To this list I would add Oscar Wilde's The Picture of Dorian Gray (1891), Henry James's The Wings of the Dove (1902) and George Gissing's The Nether World (1889) which echoes Mayhew in showing a dark version of the museum in which all that remains to collect are scraps. These novels show the museum or the museual as a place of stasis, stagnation, or burial and turn away from a blind belief in progress. Thus, while the Crystal Palace did not burn down until 1936, it is 
1914 that marks the end of the Museum Age and the end of the belief that the museum could transform entire classes of people and, indeed, entire societies.

Yet, the influence of the Victorian museum is such that it may outlast a loss of belief to enjoy a second triumph. The collectability of Victorian culture and the desire it manifests in collectors today has led to new chapters being added to the story of the Victorian museum. For instance, the great personal museum of Queen Victoria, the Albert Memorial, was saved and restored in 2000, opening with a firework display that read "Albert Saved!" As the force behind the Great Exhibition (in life) and behind the museums, monuments, and museual sprawl of South Kensington (in death), Albert's durability as a collectible lends prestige to the institutions that bear his name and contain cultural artifacts connected to the nineteenth century.

Finally, the Museum Age may see a renaissance in the years ahead. In 2013, talks began between Chinese corporations and the Mayor of London regarding the decision to rebuild the Crystal Palace. The Victorian spirit of collecting and the hope to gather all things under a single, shining lid have not lessened over the last two hundred years and, if the Crystal Palace opens its doors, we may see a largely-unknowing reenactment of Cruishank's illustration of all the world going to see it. It is to be hoped that modern visitors will realize that all of that glitter has its foundations in some very dark ideologies and that, in rebuilding the Crystal Palace, we may be reigniting, even reinstitutionalizing, them. Until a new Crystal Palace can be visited, it is to be hoped that new roads will be laid to the Crystal Palace and to the Natural History Museum and to the British Museum through the works of literature they helped to inspire and to shape. Reading these texts with the museum in mind will allow for a fuller understanding of Victorian life and culture as well as a deeper insight into the arrangement of the words on the page. 


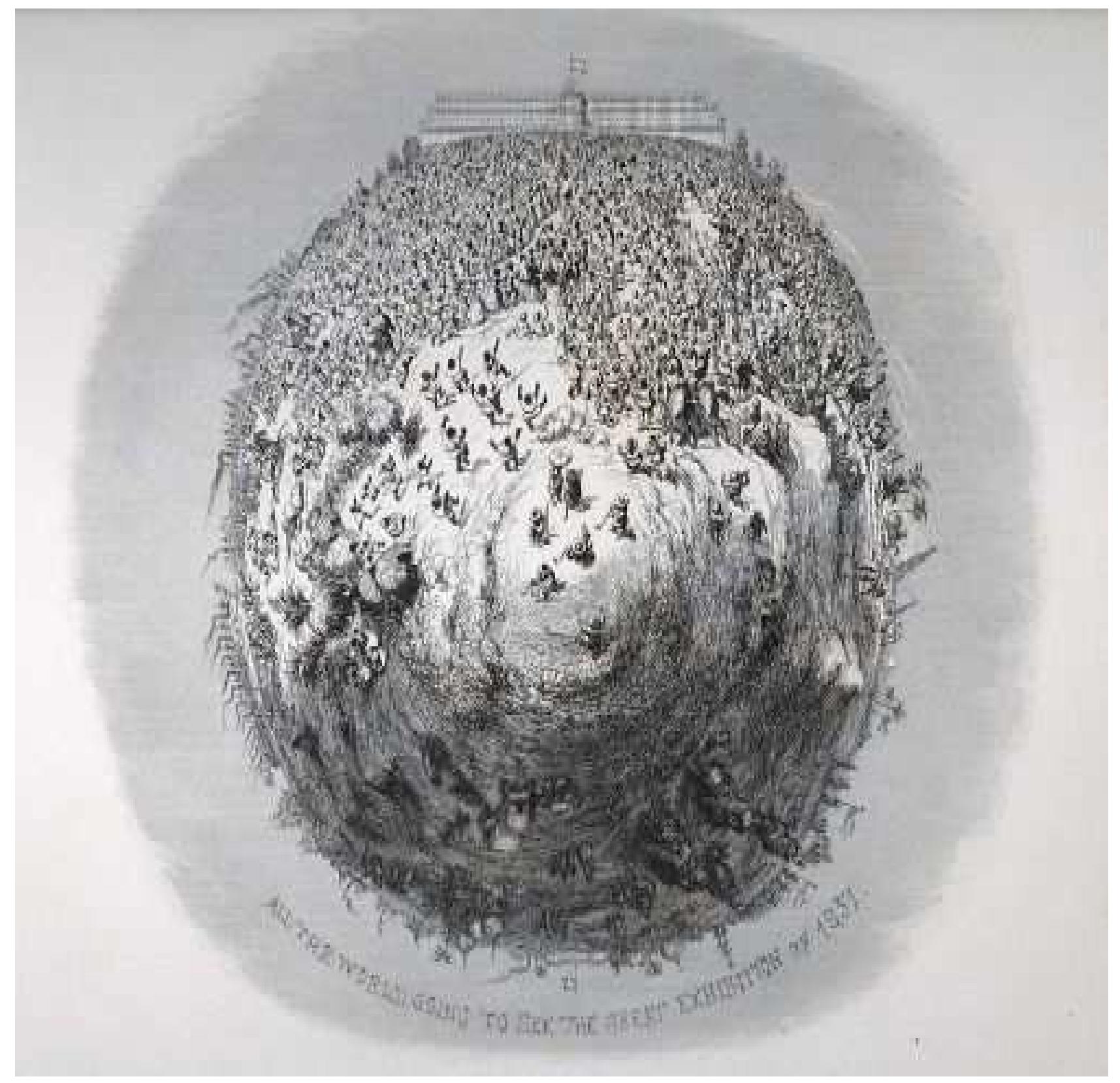




\section{Bibliography}

Ablow, Rachel. "Good Vibrations: The Sensationalization of Masculinity in The Woman in White." Novel. (2003) 158-176. Print.

Altick, Richard D. The Shows of London. Cambridge: Harvard University Press, 1978. Print.

Anderson, John G.T. Deep Things out of Darkness: A History of Natural History. Berkeley: University of California Press, 2013. Print.

Asma, Stephen T. Stuffed Animals and Pickled Heads: The Culture and Evolution of Natural History Museums. New York: Oxford, 2001. Print.

Balkun, Mary McAleer. The American Counterfeit: Authenticity and Identity in American Literature and Culture. Tuscaloosa: University of Alabama Press, 2006.

Barber, Lynn. The Heyday of Natural History. London: Jonathan Cape, 1980. Print.

Bateman, H.M. "The Boy Who Breathed on the Glass at the British Museum.” The Emergence of the Modern Museum. Jonah Siegel, ed. Oxford: Oxford University Press, 2008. Print.

Bellon, Richard. "Science at the Crystal Focus of the World." Science in the Marketplace. Aileen Fyfe and Bernard Lightman, eds. Chicago: University of Chicago Press, 2007. 231-270. Print.

Benjamin, Walter. The Arcades Project. Trans: Howard Eiland and Kevin McLaughlin. Cambridge: Belknap, 1999. Print.

Bennett, Tony. The Birth of the Museum: History, Theory, Politics. London: Routledge, 1995.

---------- "Civic Seeing: Museums and the Organization of Vision." A Companion to Museum Studies. Sharon Macdonald, ed. London: Wiley-Blackwell, 2011. Print.

Black, Barbara J. The Victorians and their Museums. Charlottesville: The University Press of Virginia, 2000. Print. 
Boev, Hristo. "De-territorialisation and Re-territorialisation in Little Nell's Death-bed Scene: Deconstructing Little Nell.” The Victorian Web. 2011. Digital.

Brand, Dana. The Spectator and the City in Nineteenth-Century American Literature. Cambridge: Cambridge University Press, 2010.

Branwen, Pratt. "Sympathy for the Devil: A Dissenting View of Quilp." Hartford Studies in Literature. 6 (1974): 129-146. Print.

Brattin, Joel J. "Some Curiosities in from The Old Curiosity Shop Manuscript." Dickens Quarterly. 7.1 (1990): 218-235. Print.

Briggs, Asa. Victorian Things. Phoenix Mill: Sutton Publishing, 2003. Print.

Buckland, Adelene. “'The Poetry of Science': Charles Dickens, Geology, and Visual and Material Culture in Victorian London." Victorian Literature and Culture. 35.2 (2007): 674-694. Print.

Burcaw, G. Ellis. Introduction to Museum Work. Nashville: American Association for State and Local History, 1975. Print.

Buzard, James. "Conflicting Cartographies: Globalism, Nationalism, and the Crystal Palace Floor Plan." Victorian Prism. James Buzard, et al., eds. Charlottesville: University of Virginia Press, 2007. 40-54. Print.

- "Enumeration and Exhaustion: Taking Inventory in The Old Curiosity

Shop." Contemporary Dickens. Eileen Gillooly and Deirdre David, eds. Columbus: The Ohio State University Press, 2009. 189-208. Print.

Casselli, Daniela. “"The “Indecent” Eternal:' Eroticism in Djuna Barnes Nightwood,” in Modernist Eroticisms: European Literature after Sexology. Anna Katherina Shaffner and Shane Weller, eds. London: Palgrave, 2012. Print. 
Chattman, Lauren. "Diagnosing the Domestic Woman in The Woman in White and Dora." Genders. 19 (1994) 123-144. Print.

Cleere, Eileen. “'Implicit Faith in the Deception:' Misanthropy, Natural History, and The Old Curiosity Shop." The Dickens Studies Annual. 35 (2005): 35-62. Print.

Cohen, William A. Embodied: Victorian Literature and the Senses. Minneapolis: University of Minnesota Press, 2009. Print.

Collins, Wilkie. The Woman in White. Oxford: Oxford University Press, 1996. Print. Cotsell, Michael. “Mr. Venus Rises from the Counter: Dickens's Taxidermist and His Contribution to Our Mutual Friend." The Dickensian. 80:2. (1984). 105-113.

Crary, Jonathan. Techniques of the Observer: On Vision and Modernity in the Nineteenth Century. Cambridge: MIT Press, 1992. Print.

Craton, Lillian. The Victorian Freak Show. New York: Cambria Press, 2007. Print.

Creaney, Conor. "Paralytic Animation: The Anthropomorphic Taxidermy of Walter Potter." Victorian Studies. 53.1 (2010): 7-35. Print.

Culbertson, Philip. "Designing Men: Reading the Male Body as Text." The Journal of Society for Textual Reasoning. 7 (1998) 11 November 2013. Digital.

Cuno, James. Who Owns Antiquity?: Museums and the Battle over our Ancient Heritage. Princeton: Princeton University Press, 2008. Print.

Cvetkovich, Ann. "Ghostlier Determinations: The Economy of Sensation in The Woman in White." Novel. 23.1 (1989) 24-43. Print.

Dalrymple, Theodore. "Why the Irish Giant's Skeleton Remains a Bone of Contention." The Telegraph. December 22, 2011. Digital. May 10, 2013.

David, Deirdre. "Children of Empire: Victorian Imperialism and Sexual Politics in Dickens and 
Kipling." Dickens and Childhood. Laura Peters, ed. London: Ashgate, 2012. Print.

Darwin, Charles. The Autobiography of Charles Darwin. Nora Barlow, ed. New York:

Norton, 1993. Print.

Dean, David and Gary Edson. Handbook for Museums. London: Routledge, 1997. Print.

Dennett, Andrea Stulman. Weird and Wonderful: The Dime Museum in America. New York:

New York University Press, 1997. Print.

Desmond, Adrian and James Moore. Darwin: The Life of a Tormented Evolutionist. New York: W.W. Norton, 1994.

Dickens, Charles. The Uncommercial Traveler. London: Chapman and Hall, 1869. Digital.

- The Old Curiosity Shop. London: Penguin, 1985. Print.

-- “Owen's Museum." All the Year Round. London: 1862. 62-67. Print.

-- "The Tresses of the Day Star.” Household Words. 65 London: 1851. 289-291.

Print.

-- Our Mutual Friend. Oxford: Oxford University Press, 2009.

The Uncommercial Traveler. http://www.gutenberg.org/etext/914

"Dickens and Little Nell: The Sculptured Memorial of the Great Author." The New York Times. September 17, 1893. Digital.

Drew, William A. Glimpses and Gatherings During a Voyage and Visit to London and the Great Exhibition in the Summer of 1851. Boston: Homan and Manley, 1852. Print.

Duncan, Carol. Civilizing Rituals: Inside Public Art Museums. London: Routledge, 1995. Print.

Durbach, Nadja. "London, Capital of Exotic Exhibitions from 1830 to 1860." Human Zoos:

Science and Spectacle in the Age of Colonial Empires. Liverpool: Liverpool University Press, 2008. 81-88. Print. 
Eliot, George. Middlemarch. New York: Oxford University Press, 2008. Print.

Erchinger, Philipp. “ Moving Things into Certain Places': Nature, Culture, and Art as Practice in Victorian Writing." Literature Compass. 9.11 (2012) 786-800. Print.

Fay, C.R. Palace of Industry, 1851. Cambridge: Cambridge University Press, 1951. Print.

Fisher, Nick. "The Great Exhibition of 1851: the struggle to describe the indescribable." Endeavor. 36.1 (2012). 6-13. Print.

Flower, William Henry. A Guide to the British Museum. London: Clowes, 1893. Print. Foucault, Michel. “Of Other Spaces.” Diacritics. 1986. Print.

- The Order of Things. New York: Vintage, 1994.

Freedgood, Elaine. The Ideas in Things: Fugitive Meanings in the Victorian Novel. Chicago: University of Chicago Press, 2006. Print. "Commodity Criticism and Victorian Thing Culture: The Case of Dickens." Contemporary Dickens. Eileen Gillooly and Deirdre David, eds. Columbus: The Ohio State University Press, 2009. 152-168. Print.

Fyfe, Aileen. "Reading Natural History at the British Museum and the Pictorial Museum." Science in the Marketplace. Aileen Fyfe and Bernard Lightman, eds. Chicago: The University of Chicago Press, 2007.196-230.

Gable, Eric. "Maintaining boundaries or 'mainstreaming' black history in a white museum." Theorizing Museums. Sharon Macdonald and Gordon Fyfe, eds. Oxford: Blackwell, 1998. 177-202. Print.

Gallagher, Catherine. The Body Economic: Life, Death, and Sensation in Political Economy and the Victorian Novel. Princeton: Princeton University Press, 2006.

Galletti, Chiara. "Curiouser and Curiouser! The Old Curiosity Shop and Little Dorrit: A 
Dickens's Curiosity Story.” Acme annali della Facoltá di lettere e filosofia dell Universitá degli studi di Milano. 45.3 (1992): 43-60. Print.

Gaylin, Ann. "The Madwoman Outside the Attich: Eavesdropping and Narrative Agency in The Woman in White." Texas Studies in Literature and Language. 43.3 (2001) 303-328. Print.

Gibson, John W. "The Old Curiosity Shop: The Critical Allegory.” The Dickensian. 60 (1964): 178-183. Print.

Giddens, Anthony. Modernity and Self-Identity: Self and Society in the Late Modern Age. Stanford: Stanford University Press, 1991.

Giffone, Tony. "Putting 'Master Humphrey’ Back Together Again.” The Journal of Narrative Technique. 7.1 (1987): 102-106. Print.

Gilbert, Pamela K. Disease, Desire, and the Body in Victorian Women's Popular Novels. Cambridge: Cambridge University Press, 2005.

Gillooly, Eileen. "Rhetorical Remedies for Taxonomic Troubles: Reading the Great Exhibition." Victorian Prism. James Buzard, et al., eds. Charlottesville: University of Virginia Press, 2007. 23-39. Print.

Ginsburg, Michael Peleg. "Sentimentality and Survival: The Double Narrative of The Old Curiosity Shop.” Dickens Quarterly. 27.2 (2010): 85-101. Print.

Glynn, M.A, et al. "Art museum membership and cultural distinction: Relating members' perceptions of prestige to benefits usage.” Poetics. 24 (1996) 259-274. Print.

Goode, G. Brown. The Principles of Museum Administration. York: Coultas and Volans, 1895. Print.

Hager, Kelly. “Jasper Packlemerton, Victorian Freak.” Victorian Literature and Culture. 34.1 
(2006): 209-232. Print.

Hallum, Kirby-Jane. "Collecting Men: Masculinity and Cultural Capital in The Woman in White." Victorian Network. 4.1 (2012) 27-47. Print.

Hennelly, Mark M. "Reading Detection in The Woman in White." Texas Studies in Literature and Language. 22.4 (1980) 449-465. Print.

Hennelly, Mark. "Carnivalesque 'Unlawful Games' in The Old Curiosity Shop.” Dickens Studies Annual. 22 (1993): 67-120. Print.

Henning, Michelle. "New Media." A Companion to Museum Studies. Sharon Macdonald, ed. London: Wiley-Blackwell, 2011. 302-318. Print.

Hibbard, Andrea. "Distracting Impressions and Rational Recreation at the Great Exhibition." Victorian Prism. James Buzard, et al., eds. Charlottesville: University of Virginia Press, 2007. 151-170. Print.

Hollington, Michael. "The Voice of Objects in The Old Curiosity Shop." The Australasian Victorian Studies Journal. 14.1 (2009): 1-8. Print.

Hooper-Greenville, Eilean. Museums and the Shaping of Knowledge. London: Routledge, 1992.

Print.

Hughes, Kathryn. The Victorian Governess. London: Hambledon, 2003. Print.

Hunt, Robert. Hunt's Hand-Book to the Official Catalogues. Volume 1. Cambridge: Cambridge University Press, 2011.

--- Hunt's Hand-Book to the Official Catalogues. Volume2. Cambridge: Cambridge University Press, 2011.

Irvin, Darcy. "Image Texts in The Woman in White." Rocky Mountain Review. 63.2 (2009) 
225-232. Print.

Jaffe, Audrey. “ 'Never be Safe but in Hiding:' Omniscience and Curiosity in The Old Curiosity Shop." Novel. 19.2 (1986): 188-134. Print.

Karp, Ivan. "Culture and Representation." Exhibiting Cultures: The Poetics and Politics of

Museum Display. Ivan Karp and Steven D. Lavine, eds. Washington: Smithsonian Institution, 1991. 11-24. Print.

Kinkaid, James R. Annoying the Victorians. London: Routledge, 1994. Print.

Klages, Mary. Woeful Afflictions: Disability and Sentimentality in Victorian America. Philadelphia: University of Pennsylvania Press, 1999. Print.

Kriegel, Lara. Grand Designs: Labor, Empire, and the Museum in Victorian Culture. Durham: Duke University Press, 2007. Print.

Landon, Philip. "Great Exhibitions: Representations of the Crystal Palace in Mayhew, Dickens, and Dostoevsky." Nineteenth-Century Contexts. 20.1 (1997). 27-58. Print.

Law, Graham and Andrew Maunder. Wilkie Collins: A Literary Life. New York: Palgrave, 2008. Print.

Ledger, Sally and Roger Luckhurst, eds. The Fin de Siecle: A Reader in Cultural History c. 1880-1900. Oxford: Oxford University Press, 2000. Print.

Levine, George. "The Test of Truth: Our Mutual Friend." Dying to Know: Scientific Epistemology and Narrative in Victorian England. Chicago: The University of Chicago Press, 2002.

MacDonald, Sharon and Gordon Fyfe, eds. Theorizing Museums. London: Wiley-Blackwell, 1996. Print.

------- "Expanding Museum Studies: An Introduction.” A Companion to Museum Studies. 
London: Wiley-Blackwell, 2011. 1-12. Print

------- "Collecting Practices.” A Companion to Museum Studies. Sharon Macdonald, ed.

Oxford: Blackwell, 2006. 81-97.

Marsden, Jonathan. Victoria and Albert: Art and Love. London: Royal Collections Enterprises, 2010. Print.

Martin, Theodore. The Life of His Royal Highness the Prince Consort. Volume 2. New York: D.

Appleton and Co, 1877. Print.

Mason, Rhiannon. "Cultural Theory and Museum Studies." A Companion to Museum Studies. Sharon Macdonald, ed. London: Wiley-Blackwell, 2011. 17-32. Print.

Maxwell, Richard. "Crowds and Creativity in The Old Curiosity Shop." The Journal of English and Germanic Philology. 78.1 (1979): 49-71.

Mayhew, Henry. London Labour and the London Poor. New York: Penguin, 1985. Print.

Mayhew, Henry and George Cruikshank. 1851 or the Adventures of Mr. and Mrs. Sandboys and family who came up to London to enjoy themselves and to see the Great Exhibition. London: David Bogue, 1851. Print.

McCann, Andrew. "Ruins, Refuse, and the Politics of Allegory in The Old Curiosity Shop." Nineteenth-Century Literature. 66.2 (2011): 170-194. Print.

McClintock, Anne. Imperial Leather: Race, Gender, and Sexuality in the Colonial Context. New York: Routledge, 1995. Print.

McKee, Patricia. Public and Private: Gender, Class, and the British Novel 1764-1878. Minneapolis: University of Minnesota Press, 1997. Print.

McKelvy, William R. "The Woman in White and Graphic Sex." Victorian Literature and 
Culture. 35 (2007) 287-308. Print.

McLean, Robert Simpson. “Another Source for Quilp.” Nineteenth-Century Fiction. 26.3 (1971): 337-339. Print.

McParland, Robert. Charles Dickens's American Audience. New York: Lexington Books, 2011. Print.

Merrill, Lynn A. The Romance of Victorian Natural History. New York: Oxford University Press, 1989. Print.

Miller, D.A. "Cage aux folles: Sensation and Gender in Wilkie Collins's The Woman in White." Representations. 14 (1986) 107-134. Print.

Muensterberger, Werner. Collecting: An Unruly Passion. Princeton: Princeton University Press, 1994.

Musiol, Hanna. "Museums of Human Bodies." College Literature. 40.3 (2013) 156-170. Print.

Noble, Mary. "Darwin among the Novelists: Narrative Strategy and the Expression of the Emotions.” Nineteenth-Century Prose. 38.1 (2011): 99-126. Print.

“On Arranging Objects in a Domestic Museum.” The Saturday Magazine. Dec 9, 1843; 23, 734; British Periodicals pg. 229.

Pacteau, Francette. Symptom of Beauty. Cambridge: Harvard University Press, 1994. Print.

Pearce, Susan M. "Objects as meanings; or narrating the past." Interpreting Objects and Collections. Susan M. Pearce, ed. London: Routledge, 1998. 19-29. Print.

Phillips, Samuel. Guide to the Crystal Palace and its Park and Gardens. London: Bradbury and Evans, 1858. Print.

Plotz, John. Portable Property: Victorian Culture on the Move. Princeton: Princeton University 
Press, 2008. Print.

Poovey, Mary. Genres of the Credit Economy: Mediating Value in Eighteenth-and Nineteenth-Century Britain. Chicago: University of Chicago Press, 2008.

Priti, Joshi. "The Other Great Exhibition: Mayhew's Catalogue of the Industrious." Literature Compass. 9.1 (2012) 95-105. Print.

Purbrick, Louise. "Defining Nation: Ireland at the Great Exhibition of 1851." Britain, the Empire, and the World at the Great Exhibition. Jeffrey A Auerbach and Peter H. Hoffenberg, eds. Hampshire: Ashgate Publishing, 2008. 47-76. Print.

Pykett, Lynn. "Collins and the Sensation Novel," in Jenny Bourne Taylor, ed., The Cambridge Companion to Wilkie Collins. Cambridge: Cambridge University Press, 2006. Print.

Qureshi, Sadiah. Peoples on Parade: Exhibitions, Empire, and Anthropology in NineteenthCentury Britain. Chicago: University of Chicago Press, 2011. Print.

Richards, Thomas. The Commodity Culture of Victorian England: Advertising and Spectacle 1851-1914. Stanford: Stanford University Press, 1990. Print.

Riegel, Henrietta. "Into the heart of irony: ethnographic exhibitions and the politics of difference.” Theorizing Museums. Sharon Macdonald and Gordon Fyfe, eds. Oxford: Blackwell, 1998. 83-104. Print.

Ritvo, Harriet. The Platypus and the Mermaid and Other Figments of the Classifying Imagination. Cambridge: Harvard University Press, 1997. Print.

Rogers, Philip. "The Dynamics of Time in The Old Curiosity Shop." Nineteenth-Century Fiction. 28.2 (1973): 127-144. Print.

Routledge's Guide through the Great Exhibition Containing a Description of Every Principal 
Object of Interest with a Plan Pointing Out the Easiest and Most Systematic Way of Examining the Contents of the Crystal Palace. London: George Routledge \& Co, 1851. Print.

Royal Commission. Official Descriptive and Illustrated Catalogue. Volume 1. London: Spicer Brothers, 1851.

--- Official Descriptive and Illustrated Catalogue. Volume 2. London: Spicer Brothers, 1851.

Rydell, Robert W. "World Fairs and Museums.” A Companion to Museum Studies. Sharon Macdonald, ed. London: Wiley-Blackwell, 2011. Print.

Schlicke, Paul. "The Old Curiosity Shop: The Assessment of Popular Entertainment." Dickens and Popular Entertainment. London: Allen and Unwin, 1985. 87-136.

Secord, James A. "How Scientific Conversation became Shop Talk." Science in the Marketplace: Nineteenth-century sites and Experiences. Aileen Fyfe and Bernard Lightman, eds. Chicago: The University of Chicago Press, 2007.

------- Victorian Sensation: The Extraordinary Publication, Reception, and Secret Authorship of Vestiges of the Natural History of Creation. Chicago: University of Chicago Press, 2000. Print.

Shields, Rob. “Fancy Footwork: Walter Benjamin's notes on flânerie.” The Flâneur. Edited by Keith Tester. London: Routledge, 1994. 61-80. Print.

Siegel, Jonah. The Emergence of the Modern Museum: An Anthology of Nineteenth-Century Sources. Oxford: Oxford University Press, 2009. Print.

Simmel, Georg. "The Metropolis and Mental Life" adapted by D. Weinstein from Kurt Wolff 
(Trans.) The Sociology of Georg Simmel. New York: Free Press, 1950, pp. 409-424.

Print.

Slater, Michael. Charles Dickens: A Life Defined by Writing. Cambridge: Yale University Press, 2009.

Sroka, Kenneth M. "The Death of Spirit and the Failure of Art in Charles Dickens's The Old Curiosity Shop." Religion and the Arts. 4.2 (2000): 185-216. Print.

Stepan, Nancy Leys. "Race and Gender: The Role of Analogy in Science." Isis 77.2 (1986) 261277. Print.

Stevens, Joan. “ 'Woodcuts Dropped into the Text:' The Illustrations in The Old Curiosity Shop and Barnaby Rudge." Studies in Bibliography. 20 (1967): 113-134. Print.

Stone, Harry. The Night Side of Dickens. Columbus: Ohio State University Press, 1994. Print.

Strout, Ruth. The Development of the Catalog and Cataloging Codes The Library Quarterly, Vol. 26, No. 4 (Oct., 1956), pp. 254-275

Sutherland, John. “ The Chronology of The Woman in White." The Woman in White. Wilkie Collins. Oxford: Oxford University Press, 1996. 662-668. Print.

Sutherland, Kathryn. "The Coming of Age of the Man of Feeling: Sentiment in Lamb and Dickens.” The Charles Lamb Bulletin. 55 (1986) 196-208. Print.

Swinburne, Algernon Charles. "The Greatness of Dickens." The Bookman. London: Hodder and Stoughtman, 1914. Digital.

Tallis's History and Description of the Crystal Palace. Volume 1. London: John Tallis and Co, 1851. Print.

Tanselle, C. Thomas. "Libraries, Museums, and Reading." Raritan. 12.1 (1992): 63-83. Print. 
Taylor, Jenny Bourne. "Psychology and Sensation: the narrative of moral management in The Woman in White." Critical Survey. 2.1 (1990) 49-56.

Teukolsky, Rachel. "White Girls: Avant-Gardism and Advertising after 1860.” Victorian Studies. $51.3(2009) 422-435$.

The Crystal Palace Exhibition Illustrated Catalogue. New York: Dover Publications, 1970. Print.

The Crystal Palace Penny Guide. London: Robert K. Burt, 1863. Print.

Tilley, Heather. “The Sentimental Touch: Dickens's Old Curiosity Shop and the Feeling Reader." The Journal of Victorian Culture. 16.2 (2011): 226-241. Print.

Treddenick, Bianca. "Some Collections of Mortality: Dickens, the Paris Morgue, and the Material Corpse.” Victorian Review. 36.1 (2010): 72-88.

Trilling, Lionel. Sincerity and Authenticity. Cambridge: Harvard University Press, 1972.

Van Dijk, Nynke and Wouter Wieling. 'Fainting, Emancipation and the 'weak and sensitive' Sex.” The Journal of Physiology. (2009) 11 November 2013. 3063-3064. Digital.

Waxman, Sharon. Loot: The Battle Over the Stolen Treasures of the Ancient World. New York: Henry Holt and Company, 2008. Print.

Ward, Rowland. A Naturalist's Life Study in the Art of Taxidermy. London: Rowland Ward Publishing, 1913.

Williams, M. Kellen. “ ‘Traced and Captured by the Men in the Chaise': Pursuing Sexual Difference in Wilkie Collins's The Woman in White." The Journal of Narrative Technique. 28.2 (1998) 91-110. Print.

Winter, Sarah. "Curiosity as Didacticism in The Old Curiosity Shop." Novel. 34.1 (2000): 28-55. Print. 
Yoon, Carol Kaesuk. Naming Nature: The Clash between Instinct and Science. New York: W.W. Norton and Company, 2009. Print.

Zemka, Sue. "From the Punchmen to Pugin's Gothics: The Broad Road to Sentimental Death in The Old Curiosity Shop." Nineteenth-Century Literature. 48.3 (1993): 291-309. Print.

Zimmerman, Virgina, ed. Excavating Victorians. Albany: State University of New York Press, 2008.

Zolberg, Vera. "Museums as contested sites of remembrance: the Enola Gay affair." Theorizing Museums. Sharon Macdonald and Gordon Fyfe, eds. Oxford: Blackwell, 1998. 69-82. Print. 